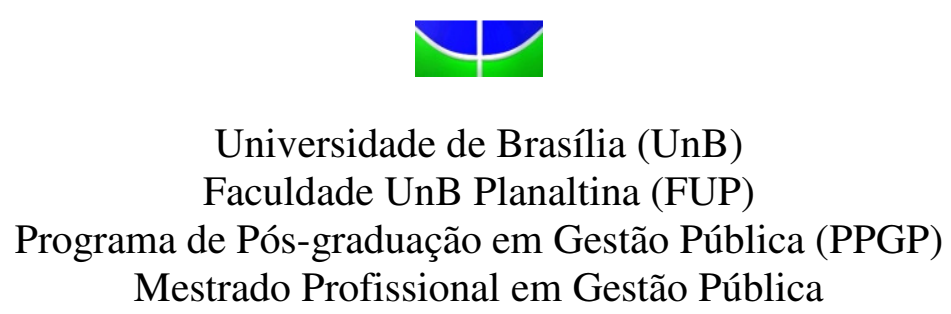

Mestrado Profissional em Gestão Pública

LAURA CRISTINA MENEZES NUNES

\title{
O EMPREGO DA TEORIA AGENTE/PRINCIPAL PARA DEFINIÇÃO DE MODELO DE GESTÃO DE BENS MÓVEIS NA UNIVERSIDADE DE BRASÍLIA
}




\section{O EMPREGO DA TEORIA AGENTE/PRINCIPAL PARA DEFINIÇÃO DE MODELO DE GESTÃO DE BENS MÓVEIS NA UNIVERSIDADE DE BRASÍLIA}

Dissertação submetida ao Programa de Pósgraduação em Gestão Pública da Faculdade UnB Planaltina, Mestrado Profissionalizante em Gestão Pública, como requisito parcial para obtenção do grau de Mestre em Gestão Pública.

Orientador: Professor Doutor André Nunes 


\section{O EMPREGO DA TEORIA AGENTE/PRINCIPAL PARA DEFINIÇÃO DE MODELO DE GESTÃO DE BENS MÓVEIS NA UNIVERSIDADE DE BRASÍLIA}

Dissertação submetida ao Programa de Pós-graduação em Gestão Pública da Faculdade UnB Planaltina, Mestrado Profissionalizante em Gestão Pública, como requisito parcial para obtenção do grau de Mestre em Gestão Pública pela Comissão Julgadora composta pelos membros:

COMISSÃO JULGADORA

\begin{tabular}{c} 
Prof. Dr. André Nunes \\
Programa de Pós-Graduação em Gestão Pública \\
Faculdade UnB Planaltina \\
Orientador \\
\hline Prof. Dr. Mário Lúcio de Ávila \\
Programa de Pós-Graduação em Gestão Pública \\
Faculdade UnB Planaltina \\
Examinador Interno \\
\hline Prof. Dr. Daniel Pitangueira de Avelino \\
Examinador Externo
\end{tabular}

Profa. Dra. Joana d`Arc Bicalho Félix

Suplente

Aprovada em de de 2015. 
Ao meu marido Paulo que lutou junto comigo para a concretização desse mestrado, sem ele eu não teria conseguido. Dedicou-se com um enorme carinho pelos nossos filhos, cuidando-os nos momentos de minhas ausências e fazendo com que os momentos difíceis dessa empreitada fossem superados pelo amor emanado nas suas atitudes. 


\section{AGRADECIMENTOS}

Agradeço a Deus pela minha existência e oportunidade de estudar e por me conceder saúde e forças para a realização deste trabalho.

Aos familiares que me deram forças ao longo do mestrado e que compreenderam os momentos da minha ausência, sobretudo meu marido, Paulo Sérgio Souza Andrade e meus filhos, Samuel Nunes Andrade e Isabel Cristina Nunes Andrade.

Ao setor de patrimônio da Universidade de Brasília pela inspiração na realização do mestrado.

Aos colegas de curso pelo bom convívio, companheirismo e apoio ao longo da Caminhada, em especial a Pedro Vieira da Silva e a Lussara Ribeiro.

Aos professores do curso pela dedicação e paciência, cujos valorosos ensinamentos tornaram possível a realização desta dissertação, especialmente a profa. Ana Cláudia Farranha Santana e ao prof. Elioenai Dornelles (in memorian).

À banca examinadora do projeto da dissertação, pelas valiosas observações e sugestões que foram bastante aproveitadas.

A todos que colaboraram para a realização da pesquisa, principalmente à disponibilidade e generosidade dos entrevistados.

Em especial ao Professor Orientador André Nunes pelo acompanhamento, dedicação, paciência e inestimáveis contribuições à concretização deste estudo. 


\section{RESUMO}

Esta pesquisa propõe aplicar a teoria agente/principal nas relações entre os servidores que possuem bens móveis sob sua responsabilidade, denominados agentes patrimoniais e a Universidade de Brasília (UnB). Utilizou-se o conceito fornecido pela Teoria da Agência que abrange os conflitos de interesses nas relações entre o agente, que no caso em questão são os agentes patrimoniais e o principal, que é a UnB, com enfoque no estudo dos mecanismos de incentivos e controle. Pretende-se construir conhecimento para solucionar ou minimizar os conflitos existentes entre o agente e o principal e consequentemente, melhorar a gestão patrimonial da UnB. Foi realizada pesquisa de campo com a aplicação de questionários e pesquisa documental com os inventários patrimoniais oriundos do setor de patrimônio. A análise desses instrumentos permitiu identificar diversos comportamentos indesejáveis por parte dos agentes patrimoniais, dificuldades de controle e monitoramento e diversos problemas na administração patrimonial, causada pela má gestão institucional. Os resultados indicam que a gestão patrimonial necessita de melhorias e inovações nos modelos atualmente empregados que produzam incentivos positivos e negativos aos agentes patrimoniais até a uma mudança na política institucional. Nesse sentido, concluiu-se pela necessidade de prover o setor de patrimônio de recursos materiais, humanos e financeiros como forma de minimizar essa perda patrimonial.

Palavras-Chave: Teoria da agência. Incentivos. Patrimônio. Agentes patrimoniais. 


\title{
EMPLOYMENT THEORY AGENT / PRINCIPAL FOR DEFINITION OF MOBILE ASSET MANAGEMENT MODEL IN BRASILIA UNIVERSITY
}

\begin{abstract}
This research proposes to apply the agent / principal theory in relations between the servers that have movable property under its responsibility, called property agents and the University of Brasilia (UnB). We used the concept provided by the Agency Theory covering conflicts of interest in the relationship between the agent, which in this case are the property agent and the principal, which is the UNB, focusing on the study of incentives and control mechanisms . It is intended to build knowledge to solve or minimize conflicts between the agent and the principal and consequently, improve asset management at UnB. Field research was conducted with the use of questionnaires and desk research with heritage inventories arising from the heritage sector. Analysis of these tools allowed us to identify several undesirable behavior by property agents, difficulties in monitoring and control and various problems in asset management, caused by poor institutional management. The results indicate that the asset management needs improvement and innovations in models currently used to produce positive and negative incentives to the economic agents to a change in institutional policy. In this sense, it was concluded by the need to provide the industry's heritage of material resources, human and financial in order to minimize this financial losses.
\end{abstract}

Keywords: Agency theory. Incentives. Heritage sector. Property agentes. Property. 


\section{LISTA DE QUADROS}

Quadro 1- Componentes Institucionais da UnB em 2014 ............................................. 19

Quadro 2- Centros de Custo que enviaram inventário ao Setor de Patrimônio em 2013 .. 67

Quadro 3- Centros de Custo que não enviaram inventário ao Setor de Patrimônio em 2013

Quadro 4- Centros de Custo que enviaram inventário, acompanhado de lista de divergência, ao Setor de Patrimônio em 2013

Quadro 5- Centros de Custo que enviaram inventário, sem lista de divergência, ao Setor de Patrimônio em 2013

Quadro 6- As 10 principais divergências e irregularidades relatadas nos inventários patrimoniais da UnB em 2013

Quadro 7- Centros de Custos Pesquisados 84 


\section{LISTA DE GRÁFICOS}

Gráfico 1- Perfil dos entrevistados por gênero ......................................................... 82

Gráfico 2- Perfil dos entrevistados por idade .......................................................... 82

Gráfico 3- Perfil dos entrevistados por tempo de serviço ............................................ 83

Gráfico 4- Perfil dos entrevistados por tempo no exercício da função de agente

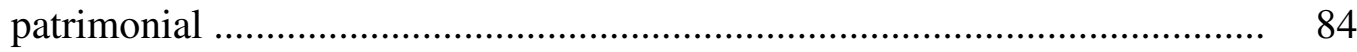

Gráfico 5- Notas auto atribuídas pelos entrevistados em avaliação de sua própria atuação como agente patrimonial .............................................................. 85

Gráfico 6- Respostas da questão aberta do questionário de entrevista .......................... 101

Gráfico 7- Resumo das respostas da questão aberta do questionário de entrevista ......... 106 


\section{LISTA DE TABELAS}

Tabela 1- $\quad$ Dados da questão 1 do questionário de entrevista .................................... 87

Tabela 2- $\quad$ Dados da questão 2 do questionário de entrevista …................................. 88

Tabela 3- Dados da questão 3 do questionário de entrevista ......................................... 88

Tabela 4- $\quad$ Dados da questão 4 do questionário de entrevista ....................................... 89

Tabela 5- $\quad$ Dados da questão 5 do questionário de entrevista ........................................ 90

Tabela 6- Dados da questão 6 do questionário de entrevista ........................................ 91

Tabela 7- Dados da questão 7 do questionário de entrevista ........................................ 92

Tabela 8- Dados da questão 8 do questionário de entrevista ........................................ 93

Tabela 9- Dados da questão 9 do questionário de entrevista ......................................... 94

Tabela 10- Dados da questão 10 do questionário de entrevista ...................................... 94

Tabela 11- Dados da questão 11 do questionário de entrevista ....................................... 95

Tabela 12- Dados da questão 12 do questionário de entrevista ...................................... 96

Tabela 13- Dados da questão 13 do questionário de entrevista ....................................... 96

Tabela 14- Dados da questão 14 do questionário de entrevista ..................................... 97

Tabela 15- Dados da questão 15 do questionário de entrevista ...................................... 98

Tabela 16- Dados da questão 16 do questionário de entrevista ....................................... 99

Tabela 17- Dados da questão 17 do questionário de entrevista ...................................... 99

Tabela 18- Dados da questão 18 do questionário de entrevista ..................................... 100 


\section{LISTA DE ABREVIATURAS E SIGLAS}

\begin{tabular}{|c|c|}
\hline ADI & Avaliação de Desempenho Individual \\
\hline $\mathrm{ADM}$ & Departamento de Administração da UnB \\
\hline ALM & Serviço de Almoxarifado da UnB \\
\hline AR & Acordo de Resultados \\
\hline AUD & Auditoria Interna da UnB \\
\hline $\mathrm{BCE}$ & Biblioteca Central da UnB \\
\hline BOT & Departamento de Botânica \\
\hline CAEP & Centro de Atendimento de Estudos Psicológicos \\
\hline CAL & Coordenadoria de Alocação de Recursos \\
\hline $\mathrm{CCA}$ & Departamento de Ciências Contábeis e Atuariais \\
\hline CCL & Casa da Cultura da América Latina da UnB \\
\hline CDS & Centro de Desenvolvimento Sustentável \\
\hline CDT & Centro de Apoio ao Desenvolvimento Tecnológico \\
\hline CEAD & Centro de Educação à Distância \\
\hline CEAM & Centro de Estudos Avançados e Multidisciplinares \\
\hline CEDOC & Centro de Documentação da UnB \\
\hline CEFTRU & Centro de Formação em Recursos Humanos em Transporte da UnB \\
\hline CEL & Departamento de Biologia Celular da UnB \\
\hline CEN & Departamento de Artes Cênicas da UnB \\
\hline CEPLAN & Centro de Planejamento Oscar Niemeyer da UnB \\
\hline CEPPAC & Centro de Pesquisa e Pós-Graduação sobre as Américas da UnB \\
\hline $\begin{array}{l}\text { CER ou } \\
\text { CERRADO }\end{array}$ & Centro de Estudos do Cerrado da Chapada dos Veadeiros da UnB \\
\hline CERME & Centro de Estudos em Regulação de Mercados \\
\hline CESPE & Centro de Seleção e Promoção de Eventos da UnB \\
\hline CET & Centro de Excelência em Turismo da UnB \\
\hline CEU & Casa do Estudante Universitário da UnB \\
\hline $\mathrm{CF}$ & Constituição Federal \\
\hline CFS & Departamento de Ciências Fisiológicas da UnB \\
\hline CGU & Controladoria Geral da União \\
\hline $\mathrm{CIC}$ & Departamento de Ciências da Computação da UnB \\
\hline CIFMC & Centro Internacional de Física da Matéria Condensada da UnB \\
\hline CIG & Coordenadoria de Informações Gerais da UnB \\
\hline CIORD & Centro Integrado de Ordenamento Territorial da UnB \\
\hline CME & Centro de Manutenção de Equipamentos Científicos da UnB \\
\hline COPP & Coordenadoria de Proteção ao Patrimônio da UnB \\
\hline CPAB & Centro de Pesquisa e Aplicação de Bambu e Fibras Naturais da UnB \\
\hline CPAI & Centro de Pesquisa em Arquitetura da Informação da UnB \\
\hline
\end{tabular}


CPCE Centro de Produção Cultural e Educativa da UnB

CPD Centro de Processamentos de Dados da UnB

CRAD Centro de Referência em Conservação da Natureza e Recuperação de Áreas Degradadas da UnB

DAC Decanato de Assuntos Comunitários da UnB

DAF Decanato de Administração Financeira da UnB

DAIA Diretoria de Acompanhamento e Integração Acadêmico da UnB

DAN Departamento de Antropologia da UnB

DATAUnB Estudos, Pesquisas e Avaliação de Políticas Públicas da UnB

DCF Diretoria de Contabilidade e Finanças da UnB

DCF Diretoria de Contabilidade e Finanças da UnB

DCO Diretoria de Compras da UnB

DDS Diretoria de Desenvolvimento Social da UnB

DEA Diretoria de Esporte Arte e Cultura da UnB

DEG Decanato de Ensino de Graduação da UnB

DEX Decanato de Extensão da UnB

DGM Diretoria de Gestão de Materiais da UnB

DGP Decanato de Gestão de Pessoas da Unb

DIN Departamento de Desenho Industrial da UnB

DISEG Diretoria de Segurança da UnB

DOR Diretoria de Orçamento da UnB

DPA Diretoria de Apoio a Projetos Acadêmicos da UnB

DPO Decanato de Planejamento e Orçamento da UnB

DPO Decanato de Planejamento e Orçamento da UnB

DPP Decanato de Pesquisa e Pós-graduação da UnB

DRU Diretoria do Restaurante Universitário da UnB

DSA Diretoria de Saúde da UnB

DSC Departamento de Saúde Coletiva da UnB

ECL Departamento de Ecologia da UnB

ECO Departamento de Economia da UnB

ECT Economia dos Custos de Transação

EDU Editora Universidade de Brasília

EFL Departamento de Engenharia Florestal da UnB

ENC Departamento de Engenharia Civil e Ambiental da UnB

ENE Departamento de Engenharia Elétrica da UnB

ENF Departamento de Enfermagem da UnB

ENM Departamento de Engenharia Mecânica da UnB

EST Departamento de Estatística da UnB

FAC Faculdade de Comunicação da UnB 
FACE

FAL

FAU

FAV

FCE

FCI

FDD

FED

FEF

FGA

FIL

FIT

FMD

FS

FSD

FTD

FUB

FUP

GEA

GEM

GRE

HIS

HUB

HVET

IBD

ICS

IDA

IED

IFAC

IFAM

IFD

IGD

IH

IHD

ILD

IN

INTERFOCO

IP

IPD
Faculdade de Economia, Administração e Contabilidade da UnB

$$
\text { Fazenda Água Limpa da UnB }
$$

Faculdade de Arquitetura e Urbanismo da UnB

Faculdade de Agronomia e Medicina Veterinária da UnB

Faculdade de Ceilândia da UnB

Faculdade de Ciência da Informação da UnB

Faculdade de Direito da UnB

Faculdade de Educação da UnB

Faculdade de Educação Física da UnB

Faculdade do Gama da UnB

Departamento de Filosofia da UnB

Departamento de Fitopatologia da UnB

Faculdade de Medicina da UnB

Faculdade de Ciências da Saúde da UnB

Direção da Faculdade de Ciências da Saúde da UnB

Direção da Faculdade de Tecnologia da Unb

Fundação Universidade de Brasília

Faculdade de Planaltina da UnB

Departamento de Geografia da UnB

Departamento de Genética e Morfologia da UnB

Gabinete do Reitor da UnB

Departamento de História da UnB

Hospital Universitário da UnB

Hospital Veterinário da UnB

Direção do Instituto de Ciências Biológicas da UnB

Instituto de Ciências Sociais da UnB

Instituto de Artes da UnB

Direção do Instituto de Ciências Exatas da UnB

International Federation of Accountants

Instituo Federal de Educação, Ciência e Tecnologia do Amazonas

Instituto de Física da UnB

Instituto de Geociências da UnB

Instituto de Ciências Humanas da UnB

Direção do Instituto de Ciências Humanas da UnB

Direção do Instituto de Letras da UnB

Instrução Normativa

Diretoria de Capacitação e Formação Continuada da UnB

Instituto de Psicologia da UnB

Direção do Instituto de Psicologia da UnB 
IPOL Instituto de Ciência Política da UnB

IQD Instituto de Química da UnB

IREL Instituto de Relações Internacionais da UnB

LET

Departamento de Línguas Estrangeiras e Tradução da UnB

LIP

Departamento de Linguística, Português e Línguas Clássicas da UnB

MAT

Departamento de Matemática da UnB

MCA

Medicina da Criança e do Adolescente da UnB

MUS

Departamento de Música da UnB

NEI

Nova Economia das Instituições

NMT

Núcleo de Medicina Tropical da UnB

NUT

Departamento de Nutrição da UnB

ODT

Departamento de Odontologia da UnB

PAT

Coordenação de Patrimônio Mobiliário da UnB

PCL

Departamento de Psicologia Clínica da UnB

PED

Departamento de Psicologia Escolar e do Desenvolvimento da UnB

PJU

Procuradoria Jurídica da UnB

PPB

Departamento de Processos Psicológicos Básicos da UnB

PPGA

Programa de Pós-Graduação em Administração da UnB

PRC

Prefeitura do Campus da UnB

PSC

Public Sector Comittee

PST

Departamento de psicologia Social e do Trabalho da UnB

SAA

Secretaria de Administração Acadêmica da UnB

SAM

Serviço de Assistência Médica da UnB

SCA

Serviço de Comunicação Administrativa da UnB

SECOM

Secretaria de Comunicação da UnB

SEDAP

Secretaria de Administração Pública da Presidência da República

SER

Departamento de Serviço Social da UnB

SGP

SIAFI

Secretaria de Gestão Patrimonial da UnB

SIPAT

Sistema Integrado de Administração Financeira do Governo Federal

SIS

Sistema de Gestão de Patrimônio Mobiliário

SME

Observatório Sismológico da UnB

SOC

Serviço de Moradia Estudantil da UnB

SOL

Seção de Órgãos Colegiados da UnB

TCU

Departamento de Sociologia

TEL

Tribunal de Contas da União

UFMG

Departamento de Teoria Literária e Literaturas da UnB

$\mathrm{UnB}$

Universidade Federal de Minas Gerais

VIS

Universidade de Brasília

Departamento de Artes Visuais da UnB 
VRT

Vice-reitoria da UnB

$\mathrm{ZOO}$

Departamento de Zoologia da UnB 


\section{SUMÁRIO}

1 - INTRODUÇÃO

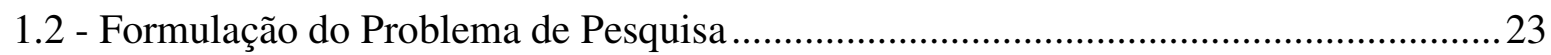

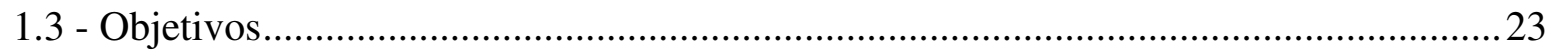

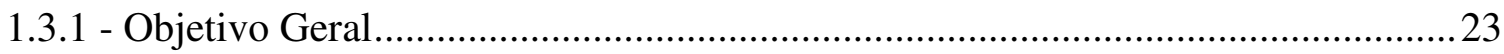

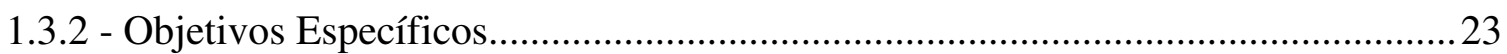

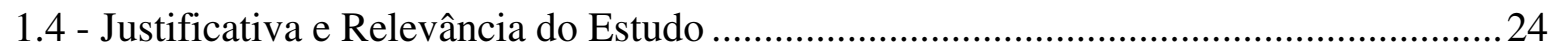

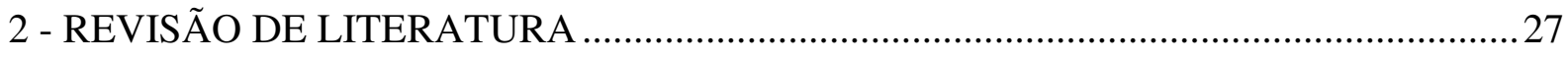

2.1 - Administração Patrimonial de Bens Móveis ..............................................................28

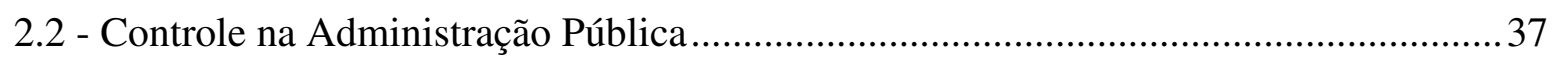

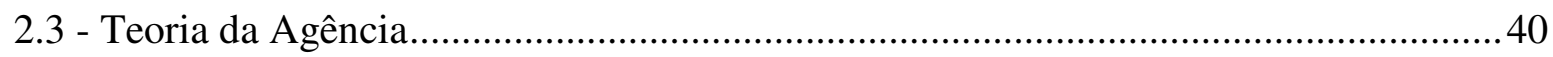

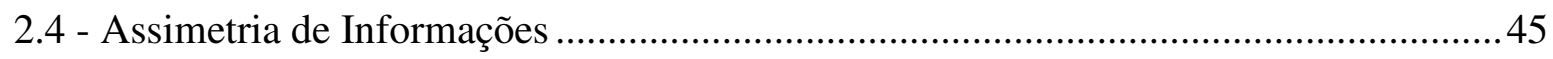

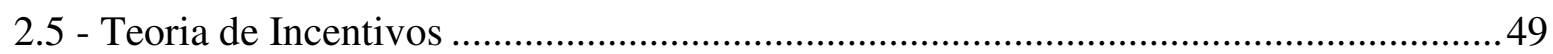

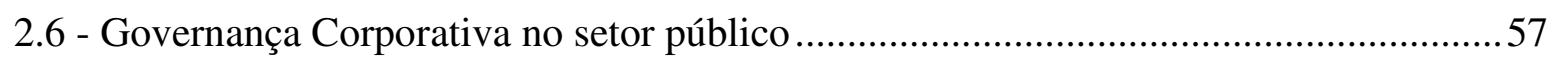

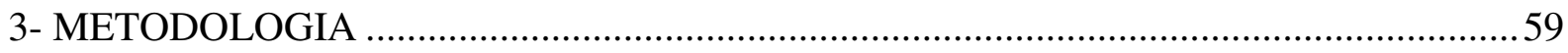

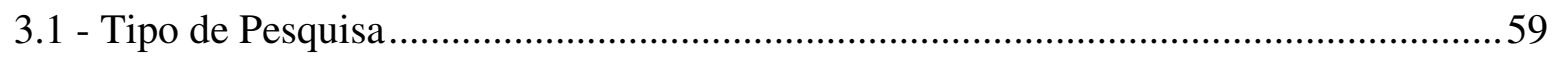

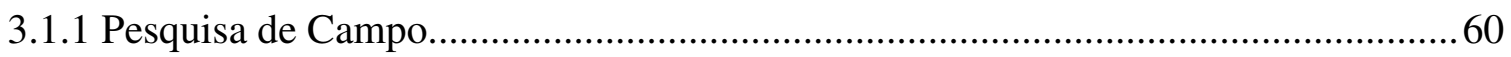

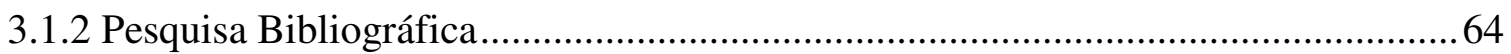

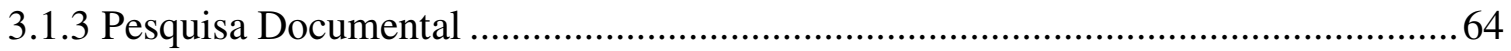

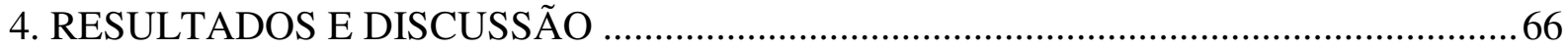

4.1 - Análise e Interpretação dos Dados Coletados no Inventário Patrimonial Anual da UnB

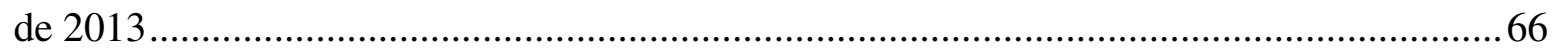

4.2 - Análise e interpretação dos dados fornecidos pelos questionários aplicados aos agentes

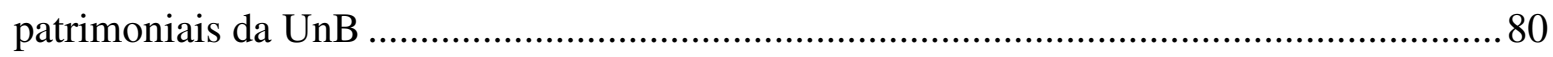

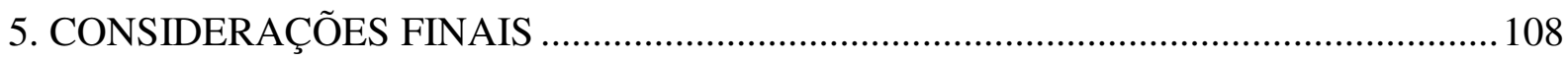

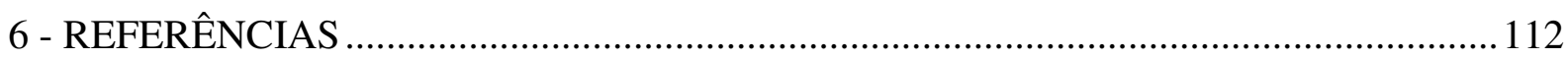

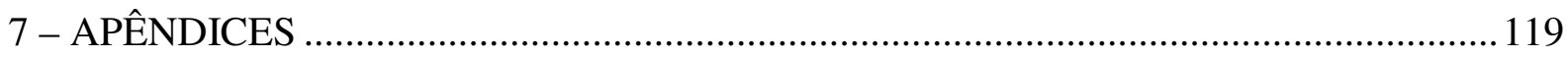

7.1 Apêndice A - Questionário ..................................................................................... 119 
7.2 Apêndice B - Relatório do Inventário Patrimonial Descentralizado da UnB do ano de 2013

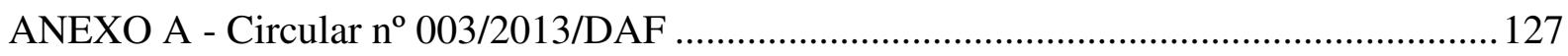

ANEXO B - Normas de Registro e Controle de Bens Patrimoniais Móveis da FUB ........... 128 


\section{1 - INTRODUÇÃO}

As transformações na administração pública e privada têm levado os gestores a tomarem providências para encaminhar ações que visem melhorar o controle patrimonial, assim como os procedimentos e rotinas operacionais devem incorporar os interesses da administração quanto a um controle eficaz, permitindo um melhor gerenciamento e planejamento do patrimônio dessas instituições.

O tema da gestão patrimonial é pouco publicado na literatura brasileira. Nesse sentido, a literatura brasileira não apresenta um diagnóstico real da situação dos setores de patrimônio, principalmente no que tange ao controle organizacional dos bens móveis da administração pública. Por essa razão, decidiu-se preencher essa lacuna através do presente estudo, mesmo diante da dificuldade de se encontrar material bibliográfico sobre o tema em questão.

A pesquisa teve como base o setor de patrimônio e os agentes patrimoniais da Universidade de Brasília (UnB). Um dos principais problemas que frequentemente se observa no setor de patrimônio é a questão do desaparecimento de bens moveis e, que consequentemente impedem muito desses servidores de se aposentarem ou até mesmo pedirem exoneração, caso não encontrem os bens desaparecidos. Assim, muitos desses servidores acabam tendo que ressarcir o valor depreciado desses bens para conseguir se aposentar ou exonerar-se. Diante dessas situações e de muitas outras, percebeu-se a necessidade de se estudar a relação dos servidores que possuem carga patrimonial, denominados agentes patrimoniais, com a Universidade no que tange a sua gestão de bens móveis. Será dado enfoque na teoria da agência e na teoria dos incentivos como forma de entender a origem dos problemas e os possíveis meios de dirimi-los. 
A Universidade de Brasília (UnB) possui atualmente cerca de 2.695 professores, 2.623 servidores técnico-administrativos, 36.372 alunos em seus cursos de graduação e 7.926 vinculados aos programas de pós-graduação. A instituição está dividida em quatro campi espalhados pelo Distrito Federal: Darcy Ribeiro (Plano Piloto), Planaltina, Ceilândia e Gama. Além das unidades de ensino e órgãos da administração, existem também os órgãos de apoio, que incluem o Hospital Universitário, a Biblioteca Central, o Hospital Veterinário e a Fazenda Água Limpa. O conhecimento dessas informações é importante para se entender a dimensão institucional onde é realizada a gestão de bens móveis patrimoniais da UnB. Segue abaixo uma tabela especificando mais detalhadamente os componentes institucionais da UnB, com base no ano de $2014^{1}$.

Quadro 1: Componentes Institucionais da UnB em 2014

\begin{tabular}{|l|r|}
\hline Decanatos & 7 \\
\hline Institutos & 12 \\
\hline Faculdades & 14 \\
\hline Departamentos & 53 \\
\hline Centros & 16 \\
\hline Secretarias & 4 \\
\hline Órgãos Complementares & 6 \\
\hline Órgãos Diversos & 10 \\
\hline Bibliotecas & 4 \\
\hline Campi & 4 \\
\hline Cursos de Graduação & 154 \\
\hline
\end{tabular}

\footnotetext{
${ }^{1}$ Disponível em: http://www.dpo.unb.br/dados institucional.php. Acessado em: 08 nov. 2015.
} 


\begin{tabular}{|c|r|}
\hline Presenciais & 145 \\
\hline A Distância & 9 \\
\hline Cursos de Mestrado & 86 \\
\hline Cursos de Doutorado & 66 \\
\hline
\end{tabular}

Fonte: CIG/DPO

A gestão patrimonial tem sido uma das áreas de grande relevância dentro das instituições, pois é dentro dela que se processa toda a política de recebimento, incorporação, conservação e distribuição de bens patrimoniais, além de se relacionar com outros segmentos internos e externos da instituição. Porém, infelizmente, na maioria das vezes, não recebe a atenção e os cuidados devidos por parte dos agentes públicos que atuam em sua execução. O objetivo principal da gestão patrimonial é ter ciência de que todo o seu patrimônio está devidamente cadastrado e controlado; identificar as deficiências e irregularidades com o acervo patrimonial, buscando resolver esses problemas e orientar as pessoas que lidam diretamente com esse acervo (BERNARDES, 2008).

O servidor público tem a obrigação de assumir responsabilidades sobre as atividades que exerce, tal como, administrar os bens que estão sob sua responsabilidade, respeitando sempre o interesse público no qual está representando. Segundo o Manual de Normas e Registro e Controle de Bens Patrimoniais Móveis da Fundação Universidade de Brasília-FUB (Anexo à Resolução no 17/2004, do Conselho Diretor da FUB) presente no Anexo B deste trabalho, todo servidor responsável por bens móveis da FUB é um agente patrimonial, destinatário de uma transferência de poderes de propriedade relativa ao uso desse mobiliário. Essa delegação é firmada por meio de um ajuste entre os atores envolvidos, formalizado através da assinatura de um Termo de Responsabilidade - termo de aceitação e concordância daquele que possui a guarda e responsabilidade sobre o bem, com as condições sob as quais o 
delegatário deve agir em nome e por conta da FUB. Ou seja, trata-se de um ajuste que disciplina a transferência da competência decisória para o servidor quanto ao uso, guarda e conservação do acervo patrimonial em sua carga patrimonial. A Relação de Carga Patrimonial é a totalidade de bens móveis sob a responsabilidade de um servidor. Com efeito, é possível adjetivar tal delegação de decisório-patrimonial, já que, embora agindo em nome de outrem (FUB), é o agente patrimonial quem deve tomar as decisões atinentes à guarda e conservação dos bens.

Nesse sentido, por meio da Teoria Agente/Principal ou Teoria da Agência, descrita por Jensen e Meckling (1976), pode-se afirmar que as interações entre a FUB e seus servidores, no que se refere à delegação decisório-patrimonial, podem ser vista como uma típica relação Agente/Principal, na qual a FUB seria o Principal e o Agente seria o agente patrimonial que detêm a responsabilidade sobre os bens patrimoniais. Portanto, a Teoria da Agência, oriunda da microeconomia, servirá como um importante instrumento para se entender as relações contratuais delegatórias que se estabelecem entre o Agente e o Principal e os conflitos presentes nesta relação.

No âmbito da Teoria da Agência, um problema encontrado é que o agente pode assumir um comportamento "oportunista" nas suas ações ou omissões, visando aumentar seus interesses e satisfação pessoal que acabam indo de encontro ao interesse do principal, gerando conflitos que são denominados "conflitos de agência". Acerca de sua aplicação no âmbito público, opinam Benedicto, Rodrigues e Abbud (2008) que:

Organizações públicas e privadas guardam semelhanças importantes no que diz respeito à governança organizacional. A separação propriedade e gestão, que gera os denominados problemas de agência, os mecanismos de definição de responsabilidades e poder, o acompanhamento e o incentivo na execução das políticas e objetivos definidos, por exemplo, são problemas comuns (BENEDICTO, RODRIGUES e ABBUD, 2008, p. 9, grifo nosso). 
Nesse sentido, constata-se a ocorrência de diversos problemas típicos do conflito de agência através do inventário patrimonial descentralizado anual da FUB, o qual consiste num levantamento geral anual de todos os bens existentes, de forma descentralizada, por todas as unidades da FUB. Levanta-se a situação dos bens em uso e a necessidade de manutenção ou reparos, a disponibilidade dos bens da unidade, bem como o saneamento do acervo. Assim, com base nesse instrumento, pode-se avaliar como está sendo feita a administração de materiais para, em seguida, atualizar os dados escriturais dos materiais que compõem o ativo da Universidade no Sistema de Gestão de Patrimônio (SIPAT), um sistema informatizado que viabiliza o registro, controle, recolhimento e descarte dos bens móveis. O inventário é enviado, anualmente, à Coordenação de Patrimônio Mobiliário - PAT, sendo, posteriormente, utilizado como instrumento de controle interno para verificação dos equipamentos e materiais permanentes.

O inventário patrimonial possui diversos objetivos, tais como: verificar a existência e localização dos bens patrimoniais; atualizar os registros e lançamentos do controle patrimonial; permitir a confrontação entre os registros do Sistema de Gestão de Patrimônio (SIPAT) e do Sistema Integrado de Administração Financeira do Governo Federal (SIAFI) com a sua posterior adequação; fornecer subsídios para melhorar a eficiência da gestão do acervo patrimonial de bens móveis; fornecer informações aos órgãos de controle para compor a prestação de contas físico-financeira da FUB no encerramento de cada exercício financeiro; confirmar as responsabilidades dos órgãos e responsáveis pela guarda dos bens móveis patrimoniais (SANTOS, 2012).

No presente trabalho, utilizaremos os conceitos fornecidos pela Teoria da Agência para compreendermos os problemas oriundos da necessidade de controle na relação Agente 
(Servidor Público) e Principal (FUB) no âmbito da gestão de bens móveis da FUB, pretendese com este estudo construir conhecimento para solucionar ou minimizar os conflitos existentes entre o agente e o principal.

\section{2 - Formulação do Problema de Pesquisa}

O presente estudo pretende responder as seguintes questões: Quais os conflitos de agência que ocorrem entre os servidores (agente) e a FUB (principal) no âmbito da sua gestão de bens móveis patrimoniais; como esses conflitos impedem uma melhor alocação de recursos públicos; como propor incentivos que levem a dirimir esses conflitos?

\section{3 - Objetivos}

\subsection{1 - Objetivo Geral}

O objetivo deste trabalho é analisar os conflitos de agência entre a FUB e os seus agentes patrimoniais de modo a gerar os possíveis incentivos que possam solucionar ou minimizar os conflitos, melhorando desta forma, a gestão de patrimônio.

\subsection{2 - Objetivos Específicos}

- identificar as principais divergências e irregularidades relatadas pelas unidades descentralizadas da UnB no inventário patrimonial do ano de 2013;

- identificar as possíveis soluções aos problemas enfrentados pelos agentes patrimoniais, propondo modificações no arranjo institucional que busquem o alinhamento de interesses entre os atores envolvidos, ou seja, a UnB e os seus agentes patrimoniais;

- identificar a existência de perfis distintos de agentes patrimoniais, criando subsídios para orientar a produção de incentivos corretos. 


\section{4 - Justificativa e Relevância do Estudo}

Não se pode olvidar que a gestão patrimonial deve ser tratada com extrema importância e atenção dentro de qualquer organização, seja pública ou privada, que pretenda controlar e registrar os seus bens patrimoniais. O controle e a movimentação correta fazem com que o bem seja identificado e localizado adequadamente sem comprometer a elaboração e execução de planejamento e alocação de recursos públicos. Além disso, o servidor que exerce corretamente as responsabilidades sobre a sua carga patrimonial evita transtornos futuros, como por exemplo, a não obtenção de certidão negativa de débitos patrimoniais nos processos de aposentadoria, redistribuição e exoneração. O zelo pelo patrimônio público não é responsabilidade apenas dos agentes patrimoniais, é responsabilidade de todos os servidores públicos e as sanções administrativas estão previstas em lei. Vale ressaltar, que a responsabilidade sobre a guarda e conservação do patrimônio institucional é atribuição, também, de estudantes e pesquisadores que, a qualquer título, frequentam a Universidade.

Do ponto de vista da teoria da agência, o Estado, no presente trabalho representado pela figura da Fundação Universidade de Brasília (FUB), apresenta-se na qualidade de Principal, já seus servidores públicos, que são responsáveis pelos bens móveis denominados agentes patrimoniais, na qualidade de Agente. Essa delegação decisório-patrimonial pode ser vista como uma típica relação Agente/Principal. O principal delega tarefas a um agente, o qual deverá executá-las tomando decisões e, espera-se, empreender o máximo de esforço para a consecução do fim almejado. Entretanto, muitas vezes isso não ocorre porque os interesses das partes envolvidas se encontram em desalinho. Assim sendo, por sua própria natureza a relação Agente/Principal é marcada por conflitos de interesse na atividade de cooperação entre as partes envolvidas, pois os interesses dos mesmos nem sempre são coincidentes. Esses conflitos ocorrem porque o agente tem interesses próprios — sua satisfação pessoal e a 
maximização de seus benefícios, dentre outros, que divergem do que espera o principal. Tais conflitos são denominados de "conflito de agência". Como exemplo prático desses conflitos de interesse, temos a divergência presente na atualização contábil dos bens móveis da FUB, quando o agente deixa de informar ao setor de patrimônio aqueles bens móveis que estão desaparecidos, o que resulta em um prejuízo na melhor alocação de recursos por parte do principal, já que a unidade que teve o bem extraviado não receberá outro em sucedâneo.

No âmbito da gestão de bens móveis de uma instituição pública, dificilmente a sociedade, destinatária dos serviços prestados pela Universidade, poderá verificar o desempenho dos agentes patrimoniais responsáveis por essa gestão. Os agentes patrimoniais da FUB possuem a informação atualizada dos bens móveis que estão sobre sua responsabilidade e que muito desses dados podem não estar sendo repassados ao setor de patrimônio da FUB, gerando assim uma enorme assimetria de informações, tanto na qualidade quanto na quantidade.

O acesso atualizado a essas informações por parte da FUB é imprescindível para se estabelecer o controle interno e externo, e consequentemente melhora na qualidade dos gastos públicos. Nesse sentido, o sistema de incentivos ao agente pode reduzir ou até mesmo eliminar essa assimetria de informação, levando-o a cumprir o que principal determinar. Portanto, para que os interesses de ambas as partes estejam alinhadas faz-se necessário que o principal consiga instituir um sistema de incentivos ao agente que propicie a diminuição desse conflito. A ideia de incentivos defende que o agente trabalhará melhor em função do principal, se obtiver recompensas pelos seus esforços. 
Na relação entre o servidor público que é agente patrimonial e a sua universidade podemos perceber que na prática existem baixos ou nenhum incentivos no que se refere às possibilidades de ganhos materiais e não materiais aos agentes. Além disso, a capacidade de aplicação de sanções aos comportamentos não desejáveis desses agentes sofre muitas restrições e condicionantes legais, assim como são objeto de revisão pelo Poder Judiciário. Nesse contexto, são imprescindíveis propostas e estudos que propiciem efetivamente o sistema de incentivos nesses arranjos organizacionais que contribuem para melhorar a gestão de bens móveis da FUB através dos agentes patrimoniais.

Assim sendo, a presente pesquisa possui uma importante relevância para a Universidade e para a Ciência, pois pretende minimizar os problemas presentes no setor de patrimônio que impedem uma melhor alocação dos recursos públicos, controle e monitoramento dos bens móveis; como também poderá servir de base teórica para o estudo dos conflitos de agência e o sistema de incentivos em outras instituições públicas.

Deste modo, almeja-se que o presente estudo possibilite um melhor entendimento da complexidade associada à definição mais clara dos mecanismos de controle de resultados na gestão do acervo patrimonial de bens móveis da FUB, identificando arranjos institucionais que economizem custos de transação aos atores envolvidos e que, igualmente, proporcionem maior bem-estar social. 


\section{2 - REVISÃO DE LITERATURA}

Neste capítulo são apresentados os principais constructos teóricos aos quais recorremos como instrumento para aferição da realidade pesquisada, como também serão apresentados os principais conceitos, definições e categorias científicas, abordados ao longo do presente trabalho e, especialmente, os pressupostos sobre os quais o estudo fora erigido. Vale ressaltar que existem inúmeras teorias que podem ser utilizadas no campo de estudo do tema em questão, porém elencamos somente algumas conforme veremos a seguir. Assim como, podemos afirmar que existem outros modelos de gestão patrimonial nas diversas instituições públicas e privadas, porém o modelo de gestão patrimonial que será trabalhado no presente estudo é o modelo atual do setor de patrimônio da Universidade de Brasília.

Inicialmente, abordar-se-á o conceito e a relevância da administração patrimonial de bens móveis nas organizações públicas; em seguida, será analisada, brevemente, a questão do controle na administração pública; posteriormente, dar-se-á ênfase à Teoria da Agência (ROSS, 1973; SAPPINGTON, 1991), com enfoque no estudo nos mecanismos de incentivos e controle. Ainda quanto à Teoria da Agência, será estudado o problema da existência potencial de conflitos de interesses nas relações entre os atores envolvidos nesse tipo de ajuste, especialmente, a assimetria de informações (AKERLOF, 1970). Será tratada, também, a teoria dos incentivos (BARNARD, 1938; AGHION e TIROLE, 1997; LAFFONT e MANTIMORT, 2002), necessária para estabelecer e identificar quais os incentivos que levam o agente a executar o que dele se espera, atendendo aos interesses do principal, dirimindo assim os conflitos de agência; e por fim, dar-se-á um enfoque na governança corporativa no setor público (MELLO, 2006), um assunto bastante relevante como forma de minimizar a assimetria de informação presente na relação Agente/Principal. 


\section{1 - Administração Patrimonial de Bens Móveis}

A gestão patrimonial diz respeito a todas as tarefas concernentes ao controle dos bens, tanto móveis quanto imóveis, desempenhadas no âmbito de uma instituição, seja pública seja privada. Essas atividades compreendem uma série de processos e rotinas, em regra, no setor de patrimônio, envolvendo tarefas como o registro, controle de localização, descarte quando o bem se torna desnecessário, para o atendimento das finalidades institucionais. Assim, para uma boa gestão patrimonial, toda instituição precisa conhecer de maneira concreta todo o seu patrimônio físico. Porém, apesar da quantidade de recursos financeiros investidos no imobiliário institucional, infelizmente, a gestão patrimonial ainda é deixada em segundo plano (BERNARDES, 2011). Para melhor compreender o tema da presente pesquisa, definiremos neste capítulo alguns termos comumente utilizados na gestão patrimonial.

No caso da Fundação Universidade de Brasília (FUB), a gestão patrimonial é administrada pela Coordenação de Patrimônio Mobiliário (PAT) subordinada da Diretoria de Gestão de Materiais (DGM), vinculadas ao Decanato de Administração Financeira (DAF) da FUB. A coordenação de patrimônio ou setor de patrimônio é o órgão responsável pela administração do acervo patrimonial móvel da UnB, o que envolve as atividades de planejamento, coordenação, execução e controle e demais as atividades relativas à gestão patrimonial (ATO DA REITORIA DA FUB Nº 1083/2013).

A Instrução Normativa/SEDAP/205/1988 e o Decreto n .99 .658 de 1990 consideram recursos materiais os equipamentos, componentes sobressalentes, acessórios, veículos em geral, equipamentos, mobiliário e outros itens empregados nas atividades das organizações. Martins e Alt (2006) classificam os bens, quanto a sua mobilidade, em imóveis ou móveis. Os 
bens imóveis não podem ser deslocados sem perder sua forma física original, como prédios, terrenos e os bens móveis podem ser deslocados sem alteração na sua forma física. São exemplos de bens móveis comumente encontrados nas instituições públicas federais: mesas; cadeiras; computadores; máquinas fotográficas; "data show”; impressoras etc. Esses bens após serem cadastrados no setor de patrimônio são tombados, recebendo uma etiqueta com seu número de identificação. Vale ressaltar, que não são bens patrimoniais, os denominados bens de consumo, como por exemplo: lápis; canetas; folhas de papel; grampeador; material de limpeza etc. A Lei n. ${ }^{\circ} 4.320$, art. $15, \S 2^{\circ}$, de 17 de março de 1964 define como material permanente aquele com duração superior a dois anos.

Segundo Santos (2012), bens móveis são aqueles que podem ser deslocados sem alteração de sua forma e geralmente constituem a maioria dos bens das instituições; o termo bem, do ponto de vista contábil, é definido como sendo "o elemento de que dispõe uma empresa ou entidade para obtenção de seus fins; e patrimônio, como o objeto administrado que serve para proporcionar à azienda (Instituição) a obtenção de seus fins" (SANTOS, 2012, p.17). O patrimônio é o conjunto de bens de toda natureza e espécies, direitos e obrigações de uma pessoa física ou jurídica que possa ser avaliado pecuniariamente e que seja utilizado na realização de seus objetivos (MARTINS e ALT, 2006). Nesse sentido, a identificação do patrimônio de uma instituição é fundamental para o sucesso de um sistema de proteção de bens, razão pela qual o mobiliário da FUB após serem cadastrados no setor de patrimônio, é tombado recebendo uma etiqueta com seu número de identificação (KRONBERG, 2002).

Desta forma, para Santos (2012), a Gestão Patrimonial envolve uma série de atividades que tem o início quando da aquisição de um dado bem e cujo término se dá quando tal bem é retirado do acervo patrimonial da Instituição ao qual pertencia. Deste modo, a 
Gestão Patrimonial possui como atividades básicas: o recebimento (acompanhamento); cadastramento; emplaquetamento; distribuição; responsabilidades; recolhimento; redistribuição; inventários; alienações e baixas. O recebimento, como o próprio nome já diz, é a operação por meio da qual o bem incorporado ao patrimônio institucional pelo setor de patrimônio, para posterior distribuição ao setor destinatário. O cadastramento consiste no registro informatizado de entrada do bem no $\mathrm{SIPAT}^{2}$, com as suas devidas características e com o seu número de identificação (plaqueta). O emplaquetamento é a colocação do número de identificação (plaqueta) no bem. A distribuição significa o encaminhamento do bem, já devidamente registrado e emplaquetado, para o seu respectivo local e agente patrimonial. Responsabilidades referem-se à emissão dos termos de responsabilidades que deverão ser assinados pelos seus respectivos agentes patrimoniais. Recolhimento é a função do setor de patrimônio responsável para colher ou receber os bens devolvidos pelos usuários. Redistribuição diz respeito ao encaminhamento dos bens que foram devolvidos para serem reutilizados em outros locais. Inventários são os procedimentos relativos ao levantamento físico dos bens da instituição. Alienações são as transferências de bens para outras instituições e por fim, a baixa, que é a última etapa no processo de gestão patrimonial, significa a retirada dos dados do bem do seu cadastro ou do sistema patrimonial físico-contábil, independente da modalidade de desfazimento (doação, transferência, permuta, venda direta, leilão, perda, roubo, extravio etc), devendo sempre ser autorizada pelo gestor da unidade.

Além das atividades patrimoniais básicas citadas acima, o Manual de Patrimônio de Administração Patrimonial de Bens Móveis do Ativo Permanente do Instituo Federal de Educação, Ciência e Tecnologia- IFAM (2012) cita as Movimentações e as Transferências como operações frequentes no setor de patrimônio. A alteração da localização de bens na

\footnotetext{
${ }^{2}$ A previsão legal do SIPAT é a Lei 4.320/1964 e na Instrução Normativa da Presidência da República no. 205/1988, como também no Anexo à Resolução no. 17/2004 do Conselho Diretor da FUB, denominado Normas de Registro e Controle de Bens Patrimoniais Móveis da FUB.
} 
instituição por manutenção ou empréstimo denomina-se Movimentação, quando não há troca pela responsabilidade por sua guarda, ou Transferência, quando há a transferência de posse e guarda para um novo responsável realizada entre unidades gestoras, sendo regularizada por meio de um Termo de Transferência de Responsabilidade, assinada pelo antigo e pelo novo agente patrimonial responsável pelo bem. $\mathrm{Na}$ rotina do setor de patrimônio da UnB, a expressão "Movimentação" é utilizada tanto quando não há troca pela responsabilidade na guarda dos bens móveis, quanto quando há a transferência de posse e guarda para um novo responsável.

O Termo de Responsabilidade, mencionado acima, é um documento de aceitação e concordância sobre a guarda e a responsabilidade da carga patrimonial que será destinada ao agente patrimonial. Ele é firmado entre o servidor e a UnB e é emitido pelo Setor de Patrimônio, em duas vias, e assinado pelo Responsável pela guarda e conservação do bem, o agente patrimonial. Os Termos de Responsabilidade serão emitidos sempre que ocorrer: registro e alocação de bens; mudança de responsável pela guarda de bens; e mudança de localização de bens dentro de uma mesma unidade gestora ou centro de custo (BERNARDES, 2008). A carga patrimonial é um termo que designa o conjunto de bens que estão efetivamente sob responsabilidade do agente patrimonial (IN/SEDAP/205/1988). Já a unidade gestora ou centro de custo é o local onde o bem será alocado fisicamente, especificado por edifício, andar, sala, terreno ou outra edificação situada na sede da instituição (SANTOS, 2012). Nesse sentido, é de suma importância para a instituição, que todo bem móvel possa ser identificado individualmente, estando atrelado a um local específico e sob a responsabilidade de um servidor. 
É definido como agente patrimonial, segundo o Manual de Normas e Registro e Controle de Bens Patrimoniais Móveis da Fundação Universidade de Brasília-FUB (Anexo à Resolução no 17/2004, do Conselho Diretor da FUB), o responsável imediato dos bens móveis de uma instituição mediante assinatura do termo de responsabilidade. $\mathrm{O}$ agente patrimonial deve ser cadastrado no Sistema de Gestão de Patrimônio (SIPAT). E no caso da UnB, este deverá pertencer ao quadro de pessoal técnico-administrativo ou do corpo docente da Universidade, sendo titular de cargo de provimento efetivo, podendo ser servidor público cedido à FUB. Deste modo, não podem ser agentes patrimoniais os funcionários terceirizados nem tampouco alunos. No que diz respeito a obrigatoriedade da função de agente patrimonial ao servidor podemos afirmar que essa obrigatoriedade somente é imposta aos servidores que possuem função comissionada de direção, chefia e assessoramento, e que os outros servidores são agentes patrimoniais por indicação da sua chefia imediata (BERNAREDES, 2008). O amparo legal que versa sobre o conjunto de atribuições e responsabilidade dos agentes patrimoniais quanto aos bens em sua carga, pode ser vista em diversas legislações, conforme a seguir:

Prestará contas qualquer pessoa física ou jurídica, pública ou privada, que utilize, arrecade, guarde, gerencie ou administre dinheiros, bens e valores públicos ou pelos quais a União responda, ou que, em nome desta, assuma obrigações de natureza pecuniária (ART. 70 da CONSTITUIÇÃO FEDERAL DO BRASIL de 1988, PÁRAGRAFO ÚNICO, grifo nosso).

Os bens móveis, materiais e equipamentos em uso ficarão sob a responsabilidade dos chefes de serviço, procedendo-se periodicamente a verificações pelos competentes órgãos de controle (ART.87, do DECRETO-LEI $\mathrm{n}^{\circ} 200$, de 25 de FEVEREIRO de 1967, grifo nosso).

Haverá registros analíticos de todos os bens de caráter permanente, com indicação dos elementos necessários para a perfeita caracterização de cada um deles e dos agentes responsáveis pela sua guarda e administração (ART.94, da LEI 4.320, de 17 de MARÇO de 1964, grifo nosso).

Nenhum equipamento ou material permanente poderá ser distribuído à unidade requisitante sem a respectiva carga, que se efetiva com o competente Termo de Responsabilidade, assinado pelo consignatário, ressalvados aqueles de pequeno valor econômico, que deverão ser relacionados (relação carga), consoante dispõe a I.N./SEDAP nº142/1983(...)

Todo servidor público poderá ser chamado à responsabilidade pelo desaparecimento do material que lhe for confiado, para guarda ou uso, bem como pelo dano que, dolosa ou culposamente, causar a qualquer material, esteja ou não sob sua guarda. 
(ITENS 7.11 e 10 da INSTRUÇÃO NORMATIVA nº 205, de 8 de ABRIL de 1988, grifo nosso).

Uma das principais atribuições do agente patrimonial é comunicar imediatamente ao setor de patrimônio qualquer alteração em sua respectiva carga patrimonial, tais como: desaparecimentos; danos; alteração nas características dos bens; extravio de plaquetas, mudança física de localização na unidade gestora, entre outras (SANTOS, 2012). Segundo, ainda, o que consta no Manual de Patrimônio da Universidade Federal de Minas GeraisUFMG (2008), são atribuições do agente patrimonial:

O zelo pela utilização correta do bem; a assinatura dos Termos de Responsabilidade
que relacionam os bens sob sua guarda; a solicitação para a manutenção ou reparo do
bem que apresentar mau funcionamento, a ser encaminhada ao responsável a que tiver
vinculado (pelo Controle do Setor ou, na sua falta, pelo Controle do Órgão, ou então,
na falta de ambos, pelo Controle da Unidade); a solicitação de tombamento de bens
que foram recebidos por doação, cessão, permuta ou comodato, diretamente no seu
local, a ser encaminhada ao responsável pelo controle patrimonial; a informação ao
responsável pelo controle patrimonial imediato da existência de bens ociosos ou
inservíveis em seu local, para as providências devidas; a imediata comunicação de
eventos relacionados ao extravio do bem (furto, roubo, movimentaçães não
autorizadas, etc.), ao responsável pela carga patrimonial do setor e ao responsável pelo
controle patrimonial (MANUAL DE PATRIMÔNIO DA UFMG, 2008, p.27).

Apesar do grande enfoque que será dado neste trabalho ao agente patrimonial, vale ressaltar que todos os servidores, indistintamente, têm o dever de zelar pela conservação e manutenção dos bens móveis da Instituição, sujeitando-se às penalidades previstas na Lei n. 8.429/1992, na hipótese de lesão ao patrimônio público, por ação ou omissão, dolosa ou culposa. Além disso, a responsabilidade sobre a guarda e conservação do patrimônio institucional é atribuição, também, de docentes, discentes e pesquisadores vinculados à Universidade a qualquer título, sejam temporários ou permanentes.

O presente trabalho analisará o Inventário físico anual da FUB relativo ao ano de 2013. De acordo com a Instrução Normativa SEDAP/205/1988, são cinco os tipos de inventários físicos: 
1. Anual: destinado a comprovar a quantidade dos bens patrimoniais do acervo de cada unidade gestora, existente em 31 de dezembro de cada exercício constituído do inventário anterior e das variações patrimoniais ocorridas durante o exercício (tombamentos, baixas, transferências);

2. Inicial: realizado quando da criação de uma unidade gestora, para identificação e registro dos bens sob sua responsabilidade;

3. De transferência de responsabilidade: realizado quando da mudança do dirigente de uma unidade gestora;

4. De extinção ou transformação: realizado quando da extinção ou transformação de um órgão;

5. Eventual: realizado em qualquer época, por iniciativa do dirigente da unidade gestora ou por iniciativa do órgão fiscalizador (INSTRUÇÃO NORMATIVA SEDAP/205/1988, grifo nosso).

O inventário anual é, em apertada síntese, o levantamento geral de todos os bens móveis de uma instituição, destinado a comprovar a quantidade dos bens patrimoniais do acervo em cada unidade gestora, existente em 31 de dezembro de cada exercício, como também o valor atualizado desse patrimônio. Ele é feito mediante o cotejo das informações atualizadas dos bens que estão sendo utilizados, prestadas pelas unidades gestoras, com os registrados informatizados. Sendo assim, todo bem móvel permanente deverá ser identificado individualmente, vinculado a um local específico e sob a responsabilidade de um servidor (BERNARDES, 2008; SANTOS, 2012). O inventário é definido pela Instrução Normativa/SEDAP/205/1988, como:

Instrumento de controle para a verificação dos saldos de estoques nos almoxarifados e depósitos, e dos equipamentos e materiais permanentes, em uso no órgão ou entidade, que irá permitir, dentre outros:

a) o ajuste dos dados escriturais de saldos e movimentações dos estoques com o saldo físico real nas instalações de armazenagem;

b) a análise do desempenho das atividades do encarregado do almoxarifado através dos resultados obtidos no levantamento físico;

c) o levantamento da situação dos materiais estocados no tocante ao saneamento dos estoques;

d) o levantamento da situação dos equipamentos e materiais permanentes em uso e das suas necessidades de manutenção e reparos; e

e) a constatação de que o bem móvel não é necessário naquela unidade (INSTRUÇÃO NORMATIVA/SEDAP/205/88, p.8).

Como determina o Manual de Normas e Registro e Controle de Bens Patrimoniais Móveis da Fundação Universidade de Brasília-FUB (Anexo à Resolução no 17/2004, do 
Conselho Diretor da FUB) e segundo a Resolução do Decanato de Administração n $^{\circ}$ 0023/2013, o trabalho de inventariar é realizado por uma subcomissão de inventário, constituída em cada um dos centros de custo da FUB. Ela é composta de no mínimo 03 (três) servidores, sendo um presidente (Titular da Unidade) e os demais membros, instituídos pelo Decano de Administração através de resolução até o final de cada exercício financeiro e em tempo hábil para a execução dos devidos levantamentos.

São facultadas as subcomissões a criação de equipes de levantamento de bens, tantas quantas julgarem necessárias, com a finalidade de realizarem o inventário de sua unidade. Competem às subcomissões, as seguintes atividades: coordenar, controlar, acompanha e finalizar as atividades relativas ao inventário; controlar o retorno de toda documentação pertinente ao inventário, por agente patrimonial; solicitar o livre acesso a qualquer local da unidade para a realização de inventário; requisitar à unidade, servidores, estagiários, equipamentos, transporte etc., e tudo que possa contribuir para o bom andamento das atividades da subcomissão; emitir relatório final de inventário da unidade no que diz respeito às informações observadas durante o processo do inventário. Cada inventário possui obrigatoriamente as seguintes peças que o instrui: a relação de carga patrimonial de cada agente da unidade, por local, contendo todos os bens localizados no inventário, assinada pelo seu respectivo agente ou no seu impedimento, pelo Titular da unidade e o relatório analítico por centro de custo, contendo todos os bens pertencentes ao acervo da unidade, devidamente assinado pela subcomissão de inventário.

Além dessas peças obrigatórias supracitadas, caso haja inconformidades nas informações dos bens, costuma-se seguir em anexo no inventário, uma lista de divergências. Nela devem ser apontadas todas as assimetrias de informação, problemas e solicitações de 
mudanças referentes aos bens que são informadas pelos centros de custo, tais como: a integridade do bem; a sua adequada localização; a correta afixação da plaqueta de identificação; se o bem está ocioso; se apresenta alguma avaria; se existe a necessidade de recolhimento ao depósito do patrimônio; se os agentes patrimoniais estão se negando a assinar os termos de responsabilidades referentes às suas respectivas cargas patrimoniais; bens desaparecidos; se existem bens sem registro; solicitações de transferências de bens entre agentes etc. Ao final de cada inventário anual, é gerado um relatório pelo setor de patrimônio da FUB indicando as correções a serem efetuadas por cada uma dos centros de custos (unidades descentralizadas) da Universidade. Em seguida, esse relatório é remetido à Diretoria de Contabilidade e Finanças da UnB (DCF) e para a Auditoria Interna (AUD).

Assim, o inventário patrimonial é uma ferramenta de controle patrimonial através do registro adequado de todos os bens móveis que estão disponíveis à Universidade de Brasília para a realização de suas atividades. Deste modo, para a eficácia do controle patrimonial é fundamental a atualização constante dos registros de entrada, atualização, movimentação e saída de bens do acervo patrimonial, pois é necessário verificar se um bem móvel está sendo bem cuidado, se está dentro da instituição ou se não foi desviado do seu propósito entre outras ocorrências. Assim sendo, o sistema de controle patrimonial, bem como os procedimentos e as rotinas operacionais a ele correlatos, deve incorporar os interesses da administração quanto a um controle eficaz, permitindo um melhor gerenciamento e planejamento do patrimônio público. Deve ser controlado todo acervo da Instituição, seja de bens móveis ou imóveis, assim como todo bem não pertencente ao acervo, mas colocado à sua disposição para consecução dos objetivos institucionais (bens em comodato). O controle é fundamental para a concretização da eficiência, o que pode ser facilitado por um bom desenho de incentivos, que 
é um instrumento de que dispõe o gestor público para garantir o alcance dos objetivos almejados (MANUAL DE PATRIMÔNIO DA UFMG, 2008).

\section{2 - Controle na Administração Pública}

A partir da promulgação da Constituição Federal do Brasil de 1988, a Administração Pública, através dos dispositivos da carta magna, passou a ter leis mais rígidas de controle contábil, financeiro, orçamentário e patrimonial, se comparada com o regime jurídico administrativo do período pretérito. Um dos exemplos práticos desse maior controle se deu através da fiscalização exercida pelos órgãos externos, como o Tribunal de Contas da UniãoTCU e a Controladoria Geral da União-CGU (BERNARDES, 2008).

O controle é parte integrante e essencial de qualquer processo de produção de bens e serviços, sendo fundamental para a concretização da eficiência. O princípio constitucional da eficiência aplicado à Administração Pública Brasileira é entendido como o dever jurídico do Poder Público realizar suas atribuições com rapidez, perfeição e rendimento (CUNHA Jr., 2009). Ou seja, o princípio constitucional da eficiência é um ditame normativo que condiciona o modo de atuar da gestão de governo e a finalidade das políticas públicas. Foi a Emenda Constitucional de número 19, de 04 de junho de 1998, quem acrescentou tal princípio ao artigo 37 da Constituição Federal brasileira de 1988, primeiro artigo do Capítulo VII que trata da Administração Pública. Isto é, a Emenda 19 alçou ao texto da Lei Maior a eficiência, transformando-a em um imperativo aplicável no âmbito da Gestão Pública em todo o país, em todas as esferas do Governo, seja federal, estadual ou municipal.

O conceito de controle na administração pública pode ser entendido como "a faculdade de vigilância, orientação e correção que um Poder órgão ou autoridade exerce sobre 
a conduta funcional de outro" (MEIRELLES, 2005, p. 645). Para Bugarin (1994, p.12), o controle na administração pública é exercido para "verificar a legalidade e o mérito e assegurar a consecução dos interesses coletivos”. Cunha Jr. (2009) define muito bem os dois tipos principais de controle, o interno e o externo. Para esse autor, o controle interno é exercido pela própria Administração Pública Direta e Indireta dos Poderes da União, dos Estados, do Distrito Federal e dos Municípios sobre a sua própria atuação; por outro lado, o controle externo na administração pública é exercido pelos Poderes Legislativo e Judiciário sobre a atividade administrativa.

A doutrina jurídica tem identificado diversas espécies de controle na Administração Pública. Ainda segundo Cunha Jr. (2009), essas espécies de controle são categorizadas quanto ao órgão que exerce o controle, como o controle administrativo, legislativo e judiciário; quanto ao momento de sua realização, como prévio, concomitante e posterior; quanto ao aspecto da atividade controlada, podendo ser de legalidade e de mérito; e por fim, com relação à extensão ou amplitude do controle, como hierárquico e finalístico.

Cunha Jr. (2009) acrescenta também que, além dos poderes públicos, o cidadão também pode exercer o controle através de dois instrumentos previstos na Carta Magna, a ação popular e o direito de petição, além desses, a C.F de 1988, no $\S 3^{\circ}$ do art. 37 prevê que a lei disciplinará as formas de participação do usuário na administração pública direta e indireta, através:

I - as reclamações relativas à prestação dos serviços públicos em geral, asseguradas a manutenção de serviços de atendimento ao usuário e a avaliação periódica, externa e interna, da qualidade dos serviços;

II - o acesso dos usuários a registros administrativos e a informações sobre atos de governo, observado o disposto no art. $5^{\circ}$, X e XXXIII;

III - a disciplina da representação contra o exercício negligente ou abusivo de cargo, emprego ou função na administração pública (CONSTITUIÇAO FEDERAL DO BRASIL DE 1988). 
A seção XI prevista na CF de 1988 versa sobre fiscalização contábil, financeira e orçamentária. Nela, existem vários artigos importantes que tratam sobre o controle na Administração Pública, elencam-se aqui alguns principais:

\begin{abstract}
Art. 70. A fiscalização contábil, financeira, orçamentária, operacional e patrimonial da União e das entidades da administração direta e indireta, quanto à legalidade, legitimidade, economicidade, aplicação das subvenções e renúncia de receitas, será exercida pelo Congresso Nacional, mediante controle externo, e pelo sistema de controle interno de cada Poder.

Art. 71. O controle externo, a cargo do Congresso Nacional, será exercido com o auxílio do Tribunal de Contas da União(...)

Art. 74. Os Poderes Legislativo, Executivo e Judiciário manterão, de forma integrada, sistema de controle interno $(\ldots) \S 1^{\circ}$ Os responsáveis pelo controle interno, ao tomarem conhecimento de qualquer irregularidade ou ilegalidade, dela darão ciência ao Tribunal de Contas da União, sob pena de responsabilidade solidária (CONSTITUIÇÃO FEDERAL DO BRASIL, 1988).
\end{abstract}

Outro exemplo prático de controle interno, bastante eficaz nas instituições públicas é a auditoria interna. Sua fundamentação legal pode ser encontrada no art. 14 do Decreto n. ${ }^{\circ}$ 3.591/2000, alterado pelo Decreto n. ${ }^{\circ} 4.440 / 2002$, onde está previsto que todas as Entidades da Administração Pública Federal Indireta deverão implantar sua Unidade de Auditoria Interna, a qual tem como finalidade básica examinar e avaliar as atividades de uma organização, fortalecendo a gestão e racionalizando as ações de controle, bem como prestando apoio aos órgãos do Sistema de Controle Interno do Poder Executivo Federal. A FUB possui, atualmente, uma Auditoria Interna. Essas Unidades de Auditoria Interna devem atuar de forma a contribuir para o alcance dos resultados quanto à economicidade, à eficiência e à eficácia da gestão. Além disso, devem propor as ações corretivas necessárias, buscando sempre agregar valor à gestão e racionalizar as ações de controle. Elas devem, também, prestar assessoramento à alta administração da entidade e estão vinculadas ao conselho de administração ou a órgão de atribuições equivalentes (CGU, 2013; CHERMAN, 2005).

Sendo assim, destaca-se o inventário patrimonial como procedimento necessário no controle do patrimônio público, pois é através dele que os bens existentes são conferidos. Os 
inventários patrimoniais na Administração Pública devem ser realizados não apenas por uma questão de rotina ou de disposição legal, mas também como medida de controle (DIAS, 2006). Resumindo, no caso da UnB, o controle patrimonial começa na assinatura de um Termo de Responsabilidade por parte do agente patrimonial que irá receber a carga patrimonial, responsabilizando-se por sua guarda e zelo. Ao final do exercício é realizado um inventário anual por meio de uma Comissão Inventariante designada pelo Reitor da universidade. Ao final do inventário a Comissão deverá entregar um relatório ao setor de patrimônio apontando as irregularidades encontradas.

Nesse sentido, dando continuidade ao tema, será dando ênfase no próximo tópico do presente estudo, a Teoria da Agência, assim, observa-se, segundo Gong (2003), que diante dos interesses divergentes na relação entre o agente e o principal, o ponto principal para minimizar esses conflitos é a formatação de um mecanismo de controle eficiente.

\section{3 - Teoria da Agência}

A expressão Agência, segundo Paula (2003), é usualmente utilizada na literatura sociológica para designar a ação humana em oposição à estrutura, em outras palavras, a Teoria da Agência que será apresentada a partir de agora tem um enfoque comportamental. A Teoria da Agência está inserida no contexto da Nova Economia das Instituições (NEI), onde se desenvolveu um novo paradigma para o estudo das organizações e surgiu quando houve a separação entre propriedade e gerenciamento de capital. Segundo Cabral (2006), a NEI promoveu a articulação de dois conceitos basilares que estão presentes na economia e sociologia: as instituições (NORTH, 1981; 1990) e os custos de transação (COASE, 1937; 1960), possibilitando o agrupamento também do conhecimento nas diversas áreas, tais como: administração; sociologia, ciência política e direito. A Teoria da Agência propõe analisar a 
influencia dos arranjos institucionais sobre o comportamento dos agentes econômicos, para melhor entender em que medida as "regras dos jogos" (NORTH, 1990) atuam no resultado das relações que ocorrem entre esses agentes, com o intuito de diminuir as incertezas provenientes da interação entre os agentes econômicos através do estudo das instituições (AZEREDO, 2007).

Para Cabral (2006), os estudos obtidos por Oliver Williamson $(1975 ; 1985 ; 1991$; 1996) foram imprescindíveis para a consolidação em um único corpo teórico dos conceitos propostos pela NEI, denominada Economia dos Custos de Transação (ECT), na qual se observa a racionalidade limitada, caracterizada pela incerteza e pela informação imperfeita, decorrendo assim os custos de transação. As transações com maior grau de incerteza levam a um controle mais complexo envolvendo custos mais elevados. Nesse sentido, Furubotn e Richter (1991) afirmam que a ECT tem como objetivo ampliar a série de aplicações da teoria neoclássica compreendendo como os direitos de propriedade e os custos de transação influenciam os incentivos e o comportamento dos agentes econômicos.

Para a efetividade do argumento da ECT, o comportamento humano oportunista não precisa necessariamente estar presente em todos os indivíduos, nem tampouco que cada indivíduo porte-se de forma oportunista o tempo todo. Basta a possibilidade de uma ação oportunista para que se justifique a inclusão de salvaguardas contratuais a fim de amenizar eventuais danos (FARINA, AZEVEDO e SAES, 1997, p. 79).

O indivíduo na racionalidade limitada não consegue exercer a melhor conduta, por mais que se esforce (SIMON, 1976). E foi Williamson (1985), que denominou de o homem contratual o agente que possui racionalidade limitada e comportamentos oportunistas ligados à assimetria de informação em ambientes hierárquicos, onde utiliza informações distorcidas e incompletas em seu próprio benefício, essa situação impede que os agentes possam agir com racionalidade plena e leva ao aumento dos custos de transação, isto é, custos presentes nos mecanismos de monitoramento, controle e nos contratos. Assim, a teoria da agência é mais 
facilmente compreendida quando observamos as características comportamentais do homem contratual.

Ainda no âmbito do estudo da Nova Economia das Instituições (NEI), ressalta-se a importância dos estudos de Ronald Coase e sua relevante contribuição para a teoria da firma. Em 1937, Ronald Coase publicou um estudo denominado The nature of the firm, explicando a gênese da firma e argumentando que as firmas podem realizar internamente as mesmas funções que os mercados. Em 1960, no estudo denominado The problem of social cost, afirmou-se que na ausência de custos de transação e que se existisse um sistema eficaz de alocação de direitos de propriedade, não há a necessidade de intervenção governamental (COASE, 1960). Esses custos de transação podem ser ex ante, tais como: elaborar, negocia e prevenir o contrato, bem como, ex post: ajustar e adaptar os contratos que sofrem de incorreções, falhas, mudanças inesperadas. Assim sendo, entende-se que na presença de assimetria de informação e de custos de transação, há a necessidade da presença das instituições para dirimir os conflitos (WILLIAMSON, 1996).

Alchian e Demsetz (1972) estudaram a natureza da firma, estabelecendo que as atividades internas de uma empresa deveriam estar embasadas nas relações contratuais. Para Jensen e Meckling (1976, p. 4, tradução nossa), o relacionamento de agência é "um contrato no qual uma ou mais pessoas - o principal - contratam outra pessoa - o agente - para desempenhar alguma tarefa em seu favor, envolvendo a delegação de autoridade para a tomada de decisão pelo agente". Segundo Azeredo (2007), o contrato deve ser compreendido como o conjunto de normas formais ou informais que normatizam a conduta dos interessados, onde as partes se responsabilizam a agir em troca de benefícios mútuos. Já para Gomes (2007, 
p.10), o contrato é definido como: "negócio jurídico bilateral, ou plurilateral, que sujeitas às partes à observância de conduta idônea à satisfação dos interesses que regularam”.

No presente estudo, observa-se uma relação contratual delegatória estabelecida entre o Agente (agente patrimonial) e o Principal (UnB), pois, existe uma manifestação de vontade escrita por esses dois atores, criando uma obrigação através do documento denominado termo de responsabilidade de bens patrimoniais. Ressalta-se ainda, que os contratos analisados sob a perspectiva da NEI não conseguem prever todas as circunstâncias futuras possíveis, e são essas lacunas contratuais que os agentes encontram oportunidades para se beneficiar. Nesse sentido, a NEI propõe analisar arranjos institucionais que coíbam ou aumentem o custo de um comportamento oportunista. Para Posner (2000):

Uma relação de agência é uma relação entre duas pessoas, um dos quais (o "principal") se beneficia quando o outro (o "agente") executa alguma tarefa. O principal se beneficia mais quando o agente cuida ou usa esforço na realização da tarefa, do que quando o agente deixa de cuidar ou usar esforço (POSNER, 2000, p.6, tradução nossa).

No estudo da Teoria do Agenciamento, segundo Eisenhardt (1989), a firma é um grande emaranhado de contratos que se misturam em vários sentidos e em diversas áreas da instituição, e esses contratos podem, inclusive, não existir necessariamente no plano físico, sendo somente informal e está presente em uma ampla abrangência de áreas, tais como: contabilidade; economia; administração; finanças; marketing; ciência política; comportamento organizacional e na sociologia. Assim sendo, a teoria da agência permitirá aos pesquisadores que se obtenha uma melhor compreensão da relação contratual e os conflitos entre o principal e o agente dentro de uma instituição pública como a Fundação Universidade de Brasília, mais especificamente, no setor de patrimônio no âmbito da gestão de bens móveis. 
Segundo Azeredo (2007), nas relações bilaterais encontradas entre o agente e o principal, no âmbito da teoria da agência, estão presentes três situações frequentemente encontradas: o agente possui vários comportamentos possíveis e muitos desses comportamentos são indesejáveis e não trazem benefício ao principal; a ação dos agentes afeta diretamente o principal, principalmente no aspecto financeiro, levando-a a uma redução dos recursos financeiros disponíveis nas organizações e por fim, as ações realizadas pelos agentes são dificilmente monitoradas pelo principal. Diante dessas situações, surge um questionamento central: como estabelecer um sistema de monitoramento e incentivos de modo que os agentes adotem uma conduta compatível com os interesses do principal?

Portanto, para que o principal se beneficie do desempenho do agente, existe a necessidade de resolução dos conflitos através dos custos de agência (agency costs), tais como: despesas de monitoramento por parte do principal (monitoring costs), que são as despesas suportadas pelo principal para controlar a atuação do agente (sistema de informações, auditoria externa ou interna, conselho fiscal etc.); despesas com a concessão de garantias contratuais por parte do agente (bonding costs), que são os encargos arcados pelo principal com o objetivo de justificar as suas decisões e com perdas residuais (residual loss), que derivam dos dois custos anteriores, pois é a riqueza perdida pelo principal em função do comportamento inadequado dos agentes. Nesse sentido, é praticamente impossível, que havendo assimetria de informação e oportunismo dos agentes, o principal consiga diminuir esses problemas a custo zero (JENSEN E MECKLING, 1976).

O conflito, segundo Robbins (2009), é definido como um processo que tem origem em uma organização quando uma das partes percebe que a outra parte afeta (ou pode afetar) de modo negativo algo considerado importante, e no momento em que o indivíduo se sente 
ameaçado em satisfazer os seus interesses poderá surgir à possibilidade de conflitos. E divide os conflitos em três tipos: o de tarefa, relacionado ao conteúdo e aos objetivos do trabalho; o de relacionamento, ligado às relações interpessoais e o de processo, que tem haver como o trabalho realizado. Para este autor, não se pode classificar os conflitos como bons ou ruins, deve-se observar a natureza dos conflitos, pois, existem conflitos funcionais e disfuncionais; os conflitos funcionais são aqueles que melhoram o desempenho do grupo cujo caráter é construtivo; em contrapartida, os conflitos disfuncionais atrapalham o desempenho do grupo.

Os conflitos presentes na sociedade são tão antigos quanto à existência do ser humano, assim, o conflito existente na relação agente e principal, não é algo necessariamente negativo, pois, se for bem administrado pode fornecer energia criativa dentro das organizações, inovando e contribuindo para a solução de diversos problemas, porém, deve-se ter a ciência, que se o conflito não for bem administrado, poderá gerar situações de estresse, levando a redução do desempenho pessoal e institucional. (SCHERMERHORN Jr., HUNT e OSBORN, 2009; MONTANA e CHARNOV, 2001).

\section{4 - Assimetria de Informações}

A informação tem um papel primordial para tomada de decisões em uma instituição, pois é a partir das informações que a instituição tem sobre si mesma, que as decisões são tomadas, assim sendo, a disponibilidade de informações está diretamente ligada à formação de estratégias. (PINTO Jr. e PIRES, 2000). O acesso à informação referente aos agentes por parte do principal é necessária para que se estabeleçam critérios de controle operacionais e financeiros alinhados com o interesse público (CABRAL, 2006). Para Brisola (2004), controle é sinônimo de poder, pois quem é detentor da informação tem maior capacidade de 
influenciar e atingir seus próprios objetivos, nesse sentido, uma das partes obtém vantagem sobre a outra envolvida no contrato, através da informação privilegiada.

O problema dos conflitos de interesse nas relações entre agente/principal possui uma grande ligação com a assimetria de informação, e ocorre quando, em uma relação, uma das partes dispõe de melhores informações que a outra. Assim, observa-se no ambiente organizacional uma falta de entendimento entre aqueles que têm a função de estabelecer as diretrizes - o principal - e aqueles que possuem o controle efetivo das ações necessárias ao cumprimento dessas diretrizes - o agente (CABRAL, 2006).

Segundo Przeworski (1998), os agentes possuem informações que o principal não dispõe, assim, os agentes sabem o que leva a motivação, outra vantagem presente na relação agente e principal, é que eles têm conhecimento privilegiado sobre as suas capacidades, e acabam observando coisas que o principal não pode ver o que leva muitas vezes a executarem ações sem que o principal detenha o devido conhecimento. Nesse contexto, tem-se um cenário institucional de indivíduos auto-interessados com objetivos conflitantes num mundo de informação incompleta.

As atividades que o principal reputa de menor importância ou necessita de conhecimento que esse não possui e são delegadas ao agente, favorecem o aumento da autoridade real desses agentes, assim sendo, a autoridade formal não implica necessariamente na autoridade real, tendo em vista que o principal desinformado acaba delegando informações ao agente bem informado e possuidor da autoridade real. Essa situação leva a uma grande dificuldade de acompanhamento dos aspectos relacionados à sua responsabilidade. Essa delegação de autoridade, muitas vezes, acontece porque o principal julga de menor 
importância determinadas atividades, as quais seriam necessárias informações que somente o agente possui, ou até mesmo quando fica impossibilitado fisicamente de acompanhar as atividades dos agentes, o que consequentemente implica em custos vindos da perda de controle pelo principal em relação às decisões feitas por terceiros (AGHION e TIROLE, 1997).

Segundo Laffont e Martimort (2002), o problema da assimetria de informação é dividido em risco moral, seleção adversa e não-verificabilidade. Assim sendo, essa situação de desconhecimento da informação pode ocorrer em dois momentos distintos: ex ante, ou seja, antes da assinatura contratual, denominada como seleção adversa ou informação oculta; e durante ou depois a execução contratual, denominada risco moral. Na seleção adversa, o agente pode escolher o inverso do que deseja o principal por não haver um esquema de incentivos bem formulados no contrato; já no risco moral, o agente utiliza de brechas contratuais agindo em interesse próprio em detrimento aos interesses do principal. Para se evitar o problema da assimetria de informação e para reduzir o comportamento oportunista dos agentes, devem-se observar os seguintes aspectos: o contrato deve prever diversos comportamentos possíveis dos agentes; um sistema de incentivo bem formulado para que o agente tenha interesse de agir de acordo com os interesses do principal e um mecanismo de seleção, monitoramento e controle confiável (ARAÚJO e SANCHEZ, 2005; AZEREDO, 2007). Gonçalves e Tavares (2008) sugerem a utilização de serviços de Auditoria como forma de minorar o problema da assimetria de informação.

Akerlof (1970), um dos pioneiros do estudo da assimetria de informação, procurou em seu artigo relacionar as questões referentes à qualidade e a incerteza nos mercados de veículos usados, demonstrando o problema da seleção adversa. Observou-se nesse estudo que as 
pessoas acabam obtendo um veículo de baixa qualidade, pagando preços que equivalem a veículos de alta qualidade, em decorrência da falta de conhecimento do nível de qualidade que é proporcionado pela assimetria de informação, ou seja, as informações do vendedor são maiores do que a do comprador.

Nesse sentido, Arrow (1985) analisa que na seleção adversa, o agente tem feito algumas observações que o principal não tem feito. $O$ agente usa (e deve usar) esta informação na tomada de decisões; entretanto, o principal não pode checar se o agente tem usado sua informação de modo que sirva da melhor forma possível aos interesses do principal. Ressalta-se ainda, que, infelizmente, na prática, a informação completa é dificilmente disponível para todos, portanto, faz-se necessário identificar uma estrutura que leve aos agentes a contribuir com o principal, mesmo quando exista assimetria de informação (ARROW, 1985).

Para Williamson (1985), existem dois mecanismos básicos de diminuição da assimetria informacional que busca a diminuir a seleção adversa: sinalização (signaling) e varredura (screening). Na sinalização o agente que possui a informação, emite sinais e fornece informações a outros agentes, ou seja, o agente que está recebendo a informação deve confiar na sinalização do outro agente. Na varredura divulga-se a informação assimétrica por iniciativa da outra parte, ou seja, os que desejam informações fornecem incentivos de modo a atrair apenas aqueles que possuem a informação desejada.

Segundo Cabral (2006), o risco moral (moral hazard) pode ser entendido como a possibilidade de apropriação do agente de uma ação/informação (hidden action/information) em benefício próprio, impondo perdas ao principal. Quanto maior a autonomia, extensão de 
informação e conhecimento técnico do agente na realização de uma determinada tarefa, maiores as chances que ocorra risco moral e, portanto, os resultados a serem alcançados possuem grande dependência da conduta dos agentes. $\mathrm{O}$ risco moral surgiu ao se estudar o mercado de seguros, onde a companhia de seguro depende da conduta moral do segurado. No risco moral o contratado executa ações diferentes da que foi prevista anteriormente no contrato (MACAGNAN, 2008).

Nesse sentido, Williamson (1985) propõe os seguintes instrumentos para evitar o risco moral: monitoramento, contratos de incentivo e joint-ventures. No monitoramento da execução do contrato, evitam-se comportamentos indesejados, antes mesmo deles aparecerem. Nos contratos de incentivo, temos a busca de comportamentos assertivos por meios de propostas de incentivos aos agentes. E na joint-ventures, tem-se a união de duas ou mais empresas compartilhando a gestão, os lucros, os riscos e os prejuízos.

Segundo Laffont e Martimort (2002), o terceiro elemento denominado de nãoverificabilidade (non-verifiability) é visto quando as duas partes - o principal e o agente possuem a mesma informação ex-post e esta não pode ser analisada por terceiros. Nesse sentido, entende-se que, grande parte das atividades realizadas pelos agentes nas instituições públicas, não são verificáveis pela sociedade.

\section{5 - Teoria de Incentivos}

Segundo Cabral (2006), um dos dilemas vistos nos conflitos de agência é estabelecer uma estrutura de incentivos que estimulem o comportamento do agente a agir da forma que atenda aos interesses do principal minimizando a assimetria de informação, estes incentivos podem abranger tanto estímulos positivos (prêmios) quanto negativos (punição), com o 
objetivo de dirimir os conflitos presentes na relação agente/principal. Ressalta-se ainda, que essa estrutura de incentivos e monitoramento afeta significativamente os indivíduos responsáveis pelas tarefas operacionais, e que acaba por influenciar os indicadores de desempenho.

A necessidade de se utilizar incentivos nas relações de trabalho foi proposta por Adam Smith (1776) na sua obra A Riqueza das Nações. Nela, discute-se o relacionamento entre os proprietários de terra e trabalhadores rurais demonstrando os problemas de incentivos presentes nesta relação. Outro estudioso importante que analisou o sistema de incentivos sobre os trabalhadores foi Chester Barnard (1938), quem descreveu as funções dos executivos nas empresas, discutiu a necessidade de incentivos para obtenção de eficiência organizacional, afirmando que os incentivos não deveriam se restringir a aspectos financeiros, mas que deveriam alcançar também a certos fatores relacionados à persuasão dos funcionários.

Laffont e Martimort (2002), por sua vez, argumentam sobre a necessidade de se firmar contratos na relação agente-principal como forma de estimular os agentes a revelar determinadas informações ocultas mediante incentivos materiais a estes agentes. Já Azevedo (1996) propôs Certificados de Garantias de Qualidade como sistema de incentivos para reduzir a assimetria de informação, e consequentemente os efeitos da seleção adversa. Outra forma de incentivo proposta por Merchant e Van der Stede (2007) é a premiação em grupo, ou seja, remunera-se todo o grupo, assim, a premiação em grupo funciona como um controle em grupo, pois estimula o monitoramento mútuo de desempenho entre os agentes.

O sistema de recompensas e punições pode estimular um ambiente que propicie à inovação, aumento da eficiência, prevenção de perdas e falhas na manutenção dos sistemas 
(CABRAL, 2006). Shirley e Ménard (2002) afirmam que o sistema de recompensas e punições como forma de incentivo proposto pode ser utilizado para evitar a assimetria de informação, mitigando o comportamento oportunista por parte dos agentes. Nesse sentido, os principais artifícios contratuais utilizados nesse sistema são: penalidades, alocação de riscos e previsão de bônus e regulação de preços. Nesse sentido, Marschke (2000) afirma que os sistemas de incentivos somente efetivamente funcionarão, se houver, um profissional habilitado em premiar os bons desempenhos e punir os maus desempenhos. Ou seja, ele precisa ser crível.

Fazendo um comparativo entre os sistemas de incentivos nas instituições públicas e privadas, Williamson (1999) afirma que na iniciativa privada os incentivos possuem maior intensidade do que nas instituições públicas. Todavia, nessas últimas o controle administrativo ocorre de forma mais rígida do que na iniciativa privada. Assim, com relação à última instância para resolver o conflito, acredita-se que o poder judiciário seria mais utilizado pela iniciativa privada, enquanto nas organizações públicas os conflitos são resolvidos internamente.

Nesse sentido, Przeworski (1998), acredita que as instituições públicas tendem a agir mais em conformidade com as regras do que através de incentivos, tão presentes nas instituições privadas. Assim sendo, o principal estabelece determinadas regras, tais como: fixação de horário de expediente das 9 às 17h; restrição ao uso do telefone para fins exclusivo da repartição; obrigatoriedade de se redigir relatórios etc. E assim os agentes são julgados pelos respeito a essas regras. Infelizmente, esse não é um modo muito eficaz de controle, pois leva a custos de monitoramento e, principalmente, impede que exista uma relação direta entre incentivo e desempenho. Esse autor propõe uma série de mecanismos que visam diminuir a 
existência de conflitos na relação agente e principal, a saber: formulação de contratos que determinem salários altos, planos de carreiras que atraiam agentes altamente qualificados e que implantem sistemas de monitoramento que levem a perda do emprego no caso de péssimo desempenho do agente; adequada triagem e seleção dos melhores agentes; fiscalização institucional, que prevê que ao se delegar uma atividade a um agente, deve haver outro agente com autoridade suficiente para coibir a ação prejudicial do agente delegatário; vários principais ou agentes com objetivos diversos, assim se obtêm uma maior eficiência nos resultados quando temos principais com objetivos contraditórios (ex: Ministérios que gastam e Ministérios responsáveis por controlar esses gastos), além de obtermos um número maior de informações quando são coletadas por agentes diversos; competição entre instituições públicas ou privadas, melhorando o desempenho do serviço por meio da concorrência e por fim, a descentralização que leva a aproximação da população com a instituição favorecendo a responsabilização do governo, por outro lado, de forma negativa, a descentralização também pode levar a capacidade do governo de minimizar as diferenças regionais, requer uma capacidade administrativa maior e pode induzir uma diminuição na distribuição orçamentária.

Para Cabral (2006), existe uma diferença bastante significativa entre o sistema de incentivos das instituições públicas e privadas. Nas instituições públicas, a estrutura estatutária do funcionalismo público apresenta algumas particularidades, que torna de difícil aplicação determinados sistemas de incentivos aplicados comumente nas empresas privadas. Tem-se como exemplo, a possibilidade de rescisão contratual, por razão de uma conduta inadequada, são bastante reduzidas nas instituições públicas, por causa da estabilidade na função e dos ritos imprescindíveis necessários ao desligamento de um servidor. Outro exemplo, é a implementação de recompensas financeiras com base em metas no setor público, é quase nulo, seja no que diz respeito a salários variáveis ou ligados aos mecanismos de 
ascensão em planos de cargos e salários direcionados ao desempenho conquistado. Branco (2011) acredita que uma das formas de incentivo nas organizações públicas seriam as promoções e os cargos comissionados, porém, infelizmente, o contrato de promoções é desvirtuado pela influencia política vistas nessas ascensões.

Ainda no âmbito público, Gomes e Diniz (2006) citam principalmente duas formas de incentivos aplicadas no Governo mineiro aos seus agentes públicos. A primeira seria a avaliação periódica de desempenho, também conhecida como avaliação de desempenho individual (ADI). Nesse contexto, o agente público que possui uma ADI satisfatória pode ser promovido e progredir na carreira (incentivos positivos), assim como uma ADI insatisfatória pode levar a demissão (incentivos negativos). O outro incentivo aplicado aos servidores estaduais mineiros é o Acordo de Resultados (AR), um instrumento de avaliação de desempenho institucional que define metas a serem cumpridas e resultados a serem alcançados. Os servidores que celebram o AR podem receber prêmio de produtividade que está intimamente ligado a três fatores: pontuação do servidor na ADI; frequência do servidor ao trabalho no período que a economia foi alcançada; e remuneração do servidor. Portanto, o AR depende do resultado geral da instituição e do resultado específico dos servidores.

Vale ressaltar que nem todo incentivo proposto para diminuir os conflitos previstos na relação agente/principal deve ser material, existem diversos incentivos não materiais (satisfação pessoal; poder de decisão; orgulho por participar de uma equipe; prestígio; posição de comando) que, igualmente, podem estimular a cooperação do agente com o principal (BARNARD, 1938). Para Roberts (2010), o sistema de incentivos exige que haja monitoramento e controle, e com esses mecanismos possamos evitar a ocorrência de injustiças nas recompensas e nas punições aplicadas aos agentes, porém, infelizmente, a rigidez presente 
nos procedimentos administrativos, tão necessários para garantir a impessoalidade no serviço público, leva a uma maior dificuldade em obter dados relacionados ao desempenho dos agentes e, consequentemente, não contribui para avaliação e comparação de resultados.

Apesar das diversas vantagens mencionadas pelo sistema de incentivos, Brennam (2005) coloca que a teoria da agência omite a complexidade da tomada de decisão, ao argumento de que nem sempre um resultado eficiente é proveniente de muito trabalho. Além disso, os incentivos podem estar desalinhados aos objetivos das instituições. Nesse sentido, um determinado incentivo pode ter importância em ambiente de negócios, mas pode não ter efeito em outras organizações, tais como instituições ligadas à saúde ou exército, sendo necessário, identificar com exatidão quais incentivos são importantes. Eisenhardt (1989) acrescenta que, apesar de haver limitações na teoria da agência, ela é de suma relevância ao afirmar que a vida organizacional está intimamente relacionada ao interesse pessoal e acredita na importância do incentivo no pensamento organizacional.

O servidor público, decerto, responde no âmbito civil, penal e administrativo pelo exercício irregular de suas funções. Nesse sentido, observam-se diversos incentivos negativos, ou seja, sanções penais, civis e administrativas aos servidores públicos que não agem com responsabilidade sobre os bens públicos. Na C.F de 1988 , no seu art. $37, \S 6^{\circ}$ pode-se observar que foi conferido ao Estado o direito de agir regressivamente contra o agente que agiu com culpa ou dolo por danos causados a terceiros. Equivale dizer que as pessoas jurídicas indenizam os prejuízos sofridos pelos terceiros, e posteriormente, cobram dos seus agentes causadores do dano valor dispêndio na reparação. Nesse sentido, a responsabilidade do agente público é subjetiva, porque, o servidor só indenizará prejuízos que tenha causado em caso de dolo ou de culpa. Ainda na CF de 1988, no seu art. 5º inciso LV, a infração administrativa 
praticada pelo servidor será apurada pela própria Administração Pública, a quem compete instaurar procedimento adequado (sindicância e/ou processo administrativo disciplinar) a esse fim, assegurando ao servidor o contraditório e a ampla defesa, com os meios e recursos a ela inerentes, inclusive com a assistência de advogado (CUNHA Jr., 2009).

No âmbito da legislação administrativa, encontra-se um conjunto de leis que tratam das possibilidades de sanções aos agentes público pela prática de ilícitos penais atinentes à malversação do patrimônio público a quem tem acesso em razão do cargo público que titulariza. Vejamo-las: a lei n. 8.429 de 2/6/1992 que dispõe sobre as sanções aplicáveis aos agentes públicos nos casos de enriquecimento ilícito no exercício de mandato, cargo, emprego ou função na administração pública direta, indireta ou fundacional e dá outras providências, define três hipóteses de improbidade administrativa: os atos de improbidade administrativa que importam em enriquecimento ilícito; que geram prejuízo ao erário público ou que atentem contra os princípios da Administração Pública. Elencam-se abaixo alguns artigos importantes da referida lei:

Art. $5^{\circ}$ Ocorrendo lesão ao patrimônio público por ação ou omissão, dolosa ou culposa, do agente ou de terceiro, dar-se-á o integral ressarcimento do dano.

Art. $7^{\circ}$ Quando o ato de improbidade causar lesão ao patrimônio público ou ensejar enriquecimento ilícito caberá à autoridade administrativa responsável pelo inquérito representar ao Ministério Público, para a indisponibilidade dos bens do indiciado.

Art. 10. Constitui ato de improbidade administrativa que causa lesão ao erário qualquer ação ou omissão, dolosa ou culposa, que enseje perda patrimonial, desvio, apropriação, malbaratamento ou dilapidação dos bens ou haveres das entidades (....)

Art. 12. Independentemente das sanções penais, civis e administrativas previstas na legislação específica, está o responsável pelo ato de improbidade sujeito às seguintes cominações, que podem ser aplicadas isolada ou cumulativamente, de acordo com a gravidade do fato:

(...) II - na hipótese do art. 10, ressarcimento integral do dano, perda dos bens ou valores acrescidos ilicitamente ao patrimônio, se concorrer esta circunstância, perda da função pública, suspensão dos direitos políticos de cinco a oito anos, pagamento de multa civil de até duas vezes o valor do dano e proibição de contratar com o Poder Público ou receber benefícios ou incentivos fiscais ou creditícios, direta ou indiretamente, ainda que por intermédio de pessoa jurídica da qual seja sócio majoritário, pelo prazo de cinco anos (LEI 8.429 de 2/6/1992). 
Outra lei que é bastante utilizada na apuração de indícios de irresponsabilidade cometidos pelo servidor público é a lei 8.112 de 11/12/1990, que dispõe sobre o regime jurídico dos servidores públicos civis da União, das autarquias e das fundações públicas federais. Os títulos IV e V do referido diploma legal versam sobre o regime disciplinar e do processo administrativo disciplinar, vejamos a seguir alguns artigos principais:

Art. 116. São deveres do servidor:

(... ) VII - zelar pela economia do material e a conservação do patrimônio público;

Art. 121. O servidor responde civil, penal e administrativamente pelo exercício irregular de suas atribuições.

Art. 122. A responsabilidade civil decorre de ato omissivo ou comissivo, doloso ou culposo, que resulte em prejuízo ao erário ou a terceiros.

Art. 123. A responsabilidade penal abrange os crimes e contravenções imputadas ao servidor, nessa qualidade.

Art. 143. A autoridade que tiver ciência de irregularidade no serviço público é obrigada a promover a sua apuração imediata, mediante sindicância ou processo administrativo disciplinar, assegurada ao acusado ampla defesa (LEI 8.112 de 11/12/1990).

Encontramos também incentivos negativos nas normas internas da Universidade, subsidiada pela lei 8.112/1990, tal como, a não obtenção de certidão negativa de débitos patrimoniais, assim, na ausência dessa certidão, o servidor público fica impossibilitado de obter a aposentadoria, redistribuição e exoneração. Outra penalidade interna prevista na Resolução do Decanato de Administração nº 0023/2013 é o impedimento de registro de empenho das unidades que não realizaram o Inventário Patrimonial junto às Diretorias de Compras e de Contabilidade e Finanças.

No âmbito da legislação penal, o servidor responde penalmente quando pratica crime ou contravenção. A responsabilidade penal diz respeito às consequências da prática pelo servidor público de condutas tipificadas como crimes relacionados ao exercício de cargo, 
função ou emprego público. O decreto-lei $n^{0}$ 2.848, de 7/12/1940 que disciplina o código penal, tem no seu art. 312 o crime de peculato:

Art. 312 - Apropriar-se o funcionário público de dinheiro, valor ou qualquer outro bem móvel, público ou particular, de que tem a posse em razão do cargo, ou desviá-lo, em proveito próprio ou alheio:

Pena - reclusão, de dois a doze anos, e multa.

$\S 1^{\circ}$ - Aplica-se a mesma pena, se o funcionário público, embora não tendo a posse do dinheiro, valor ou bem, o subtrai, ou concorre para que seja subtraído, em proveito próprio ou alheio, valendo-se de facilidade que lhe proporciona a qualidade de funcionário (DECRETO-LEI n ${ }^{\circ}$ 2.848, de 7/12/1940).

A responsabilidade civil é de ordem patrimonial e se encontra prevista nos artigos 186 e 927, ambos do Código Civil, os quais consagram a regra segundo a qual todo aquele que causa dano a outrem é obrigado a repará-lo. Se for responsabilizado civilmente, o servidor deverá reparar o dano que, por ação ou omissão, dolosa ou culposa, tenha causado à Administração.

Como visto, no âmbito das instituições federais de ensino, que integram o serviço público, os únicos incentivos encontrados são os negativos (penalidades previstas em lei), e é por isso que o presente trabalho pretende analisar de que forma podem-se oferecer incentivos positivos para que se busque o alinhamento de interesse entre a UnB e os servidores responsáveis pelos bens móveis.

\section{6 - Governança Corporativa no setor público}

Segundo Carvalho (2002), uma das formas de minimizar os problemas de agência, principalmente, a assimetria de informação, é a através da Governança Corporativa. A Governança Corporativa é definida pelo Código das Melhores Práticas de Governança Corporativa (IBGC, 2009, p.19) como sendo:

O sistema pelo qual as organizações são dirigidas, monitoradas e incentivadas, envolvendo os relacionamentos entre proprietários, Conselho de Administração, Diretoria e órgãos de controle. As boas práticas de Governança Corporativa convertem princípios em recomendações objetivas, alinhando interesses com a 
finalidade de preservar e otimizar o valor da organização, facilitando seu acesso a recursos e contribuindo para sua longevidade (IBGC, 2009, p.19).

A Governança Corporativa engloba o conceito de Teoria da Agência no que diz respeito aos conflitos de agência e, principalmente, ao tentar manter as ações dos agentes em consonância com os interesses do principal. A Governança Corporativa é um conjunto de prática que visa monitorar as relações existentes entre os agentes, minimizando as diferenças existentes entre eles, além disso, garante que os recursos sejam utilizados de forma eficiente e eficaz na organização, assim sendo, aumentando os ganhos econômicos da organização (ARRUDA, MADRUGA, FREITAS Jr., 2008). Segundo Bhide (1994), a relação do agente com o principal possui uma forte influência na governança da organização, sendo assim, no âmbito dessa relação, sempre existirão ocasiões diversas para se negligenciar ou esquivar-se de responsabilidades.

A organização que decide por utilizar as boas práticas de governança corporativa adota como princípios: a transparência, a prestação de contas e a equidade, sendo imprescindível, que o Conselho de Administração estabeleça estratégias para as organizações, elegendo a Diretoria, fiscalizando e avaliando o desempenho da gestão e escolhendo a auditoria independente (OLIVEIRA et al., 2004). A boa governança nas organizações leva ao aumento da transparência, disciplina e responsabilidade, bem como a diminuição da assimetria de informação existente entre a empresa e os diversos agentes envolvidos, sejam clientes, acionistas credores, fornecedores, empregados ou gestores (VIEIRA e MENDES, 2006).

Infelizmente, segundo Mello (2006), poucos estudos são focados na governança corporativa no setor público e com pouca possibilidade de adaptação, a maioria desses estudos tenta adaptar os princípios da governança do setor privado para o público. A governança corporativa no setor público federal brasileiro pode ser observada com a 
aplicabilidade dos princípios e recomendações da governança corporativa para o setor público, indicado no estudo 13 do Public Sector Comittee (PSC) da International Federation of Accountants (IFAC), cujo objetivo é fornecer informações à sociedade e os agentes públicos sobre o desempenho da boa governança corporativa. O PSC é o comitê do setor público da Federação Internacional de Contadores (IFAC) formado com o intuito de se dedicar a coordenação mundial das necessidades do envolvimento do setor público nos relatórios financeiros, contabilidade e auditoria. De acordo com o estudo 13 do PSC/IFAC (2001), os princípios norteadores para a boa governança corporativa no setor público são: transparência, integridade e responsabilidade em prestar contas. Esses princípios estão relacionados aos padrões de comportamento humano; nas estruturas e processos organizacionais e no controle (MELLO, 2006). Portanto, Benedicto, Rodrigues e Abbud (2008) afirmam que embora o surgimento da governança corporativa tenha ocorrido com empresas de capital aberto, pode ser aplicada a qualquer tipo de organização, inclusive as púbicas. Nesse sentido, a sociedade necessita de uma boa governança corporativa das suas autoridades governamentais e, por isso, torna-se imprescindível que os cidadãos exijam a transparência na prestação de contas.

\section{3- METODOLOGIA}

\section{1 - Tipo de Pesquisa}

A pesquisa do presente estudo qualificou e quantificou os dados, analisou a qualidade das informações e obteve a percepção dos agentes envolvidos. Para tanto, do ponto de vista metodológico, foi realizado uma pesquisa de campo utilizando questionários; uma pesquisa bibliográfica, focada na teoria da agência, e; uma pesquisa documental com os dados oriundos do setor de patrimônio. 


\subsubsection{Pesquisa de Campo}

$\mathrm{Na}$ pesquisa de campo, empregou-se um questionário elaborado pelo autor da pesquisa. Ele foi aplicado de forma aleatória a uma parcela da população de servidores e professores que possuem função de agentes patrimoniais da FUB, presencialmente e por email. O questionário foi imprescindível para se analisar o foco principal desse estudo, que são os conflitos existentes entre o principal e o agente. O questionário deu voz ao agente patrimonial, sobre o qual cabe a delegação decisório-patrimonial.

O questionário é um instrumento de pesquisa constituído por uma série de questões sobre determinado tema (VIEIRA, 2009). O uso do questionário permite o anonimato das respostas, esse anonimato confere ao respondente maior liberdade para expor sua opinião, além de um maior tempo para preenchê-lo, pois não há a necessidade da presença física do pesquisador. Outra vantagem encontrada com o uso do questionário é que esse instrumento possui perguntas iguais a todos os respondentes e as possibilidades de resposta também são iguais; essa uniformidade é imprescindível para analisarmos e interpretarmos os dados de forma estatística. Além disso, o questionário possibilita abranger um maior número de informações e obtê-las em um espaço de tempo mais curto que o utilizado em entrevistas e observações. (SELLTIZ et al., 1972; VERGARA, 2009).

As questões do questionário foram elaboradas com o intuito de obter diversas opiniões e informações relevantes, principalmente sobre os motivos que levam aos conflitos ente o Principal e o Agente, tendo como parâmetro de aferição as normas da FUB aplicáveis ao ajuste entre seus comitentes, os agentes patrimoniais delegados. As normas representam a vontade do principal, são elas que personificam a vontade institucional. Além disso, com 
base nas informações obtidas com o emprego do questionário é possível evidenciar quais os incentivos que os agentes acreditam que possam dirimir os principais conflitos.

Os assuntos abordados nos questionários foram elaborados a partir das informações fornecidas pela pesquisa documental (inventários patrimoniais anuais). Segundo Santos (2012), o levantamento geral dos bens presentes nos inventários patrimoniais permite um embasamento teórico para identificarmos e corrigirmos problemas que podem ser de responsabilidade dos agentes patrimoniais. Sendo organizado em partes com ênfase nas seguintes questões que podem influenciar na responsabilidade sobre a carga patrimonial e, consequentemente, produzir conflitos entre os agentes e a FUB: influência da compatibilidade de carga horária entre a função para a qual está empregado e a de agente patrimonial; influência de incentivos monetários e não monetários; influência de um ambiente organizacional propício a controle dos bens móveis; influência do controle externo/interno sobre os bens móveis; influência da estabilidade profissional dos servidores/docentes na responsabilidade das cargas patrimoniais; influência do conhecimento sobre a responsabilidade legal dos agentes patrimoniais; influência da quantidade e valor dos bens que estão sob responsabilidade dos agentes patrimoniais.

Os assuntos supracitados correspondem às principais justificativas apresentadas pelos agentes patrimoniais delegados da FUB para esclarecer as divergências entre o acervo patrimonial in loco e os dados informatizados no SIPAT ou a dificuldade de cumprimento de suas obrigações para com o Principal, como se observa em diversos documentos, principalmente, nos Inventários Patrimoniais Anuais. 
A princípio, o questionário foi aplicado na forma de pré-teste para um limitado número de agentes patrimoniais, exatamente cinco agentes patrimoniais. Esse pré-teste é recomendado por Barbetta (2003) com o intuito de melhor adequar o questionário para a compreensão dos agentes patrimoniais com o objetivo de avaliar a consistência, clareza e entendimento das questões. Após a aplicação do questionário para cinco agentes patrimoniais, foram ouvidas as contribuições propostas por esses servidores e em seguida, foram feitas reformulações nas questões que se apresentaram com problemas de má interpretação, e o questionário resultante desse processo serviu de base para ser aplicado aos agentes patrimoniais. O questionário que foi utilizado nesta pesquisa encontra-se no apêndice A.

Com a aplicação dos questionários aos agentes patrimoniais, foi avaliado o tamanho da amostra dos dados e o perfil dos entrevistados com relação ao gênero, idade, tempo de serviço na universidade, período de tempo como agente patrimonial. Esses dados descritivos são importantes para identificar o perfil do agente patrimonial e as possíveis relações com as respostas fornecidas (VIEIRA, 2009).

A validação do questionário será verificada através do coeficiente alpha de cronbach, por meio do software estatístico IBM SPSS, versão 20.0.0, onde se permite analisar em que grau os itens do questionário estão inter-relacionados (HAYES, 2001). Segundo Ledesma (2004, p.32), “o alpha de cronbach estima o limite do coeficiente inferior do coeficiente de confiabilidade, em função de dois componentes do teste: o número de itens e proporção da variância total da amostra".

O questionário possui questões fechadas, utilizando uma escala de classificação do tipo Likert de 5 pontos, sendo o menor ponto da escala, o número 1, que significa "discordo 
totalmente" e o maior ponto, o número 5, que significa "concordo totalmente", e portanto sendo o 3 o ponto médio. Segundo Hayes (2001), esse tipo de escala fornece alto grau de coeficiente de confiabilidade. Durante a análise dos resultados, além do porcentual de concordância/discordância encontrado, será apresentada a média obtida em cada uma das questões do questionário. Nessa análise, será obtido também o desvio padrão, o que irá permitir reduzir eventuais distorções pela interpretação da média pura e simples. Assim, considerando-se as limitações de interpretação pela média e sabendo-se ser essa uma informação complementar, será entendido que um ponto médio acima de três indicará concordância com a questão apresentada pelo questionário, enquanto um ponto médio abaixo de três indicará haver discordância daquela questão.

Além das questões fechadas, o questionário possui uma questão aberta que versa sobre os benefícios que a FUB poderia propor para estimular a atividade dos agentes patrimoniais. O objetivo dessa pergunta aberta é coletar entre os entrevistados diversas sugestões de incentivos que poderiam ser fornecidos pela FUB para estimular os agentes patrimoniais a exercerem a sua função. Portanto, o perfil dos agentes patrimoniais; o comportamento e as suas opiniões; o ambiente organizacional e os potenciais motivos determinantes dos conflitos entre estes agentes e a FUB são informações que se pretende obter com a aplicação dos questionários e que subsidiará a análise da relação de cooperação entre a FUB e os agentes patrimoniais no que se refere a sua gestão de bens móveis. Em consequência buscar, com base nas respostas desses questionários, soluções que levem a dirimir os conflitos entre a FUB e seus agentes patrimoniais. 


\subsubsection{Pesquisa Bibliográfica}

Ressalta-se que a pesquisa bibliográfica (ALYRIO, 2009) foi responsável por nos fornecer sustentação e fundamentação teórica no processo de construção dos instrumentos de pesquisa e coleta de dados. A pesquisa bibliográfica possibilitou identificar os conceitos, definições e importância da administração patrimonial de bens móveis nas organizações públicas. Tratou-se também do controle na administração pública como forma para se obter um melhor gerenciamento e planejamento do patrimônio público. Foi dada ênfase à Teoria da Agência (ROSS, 1973; SAPPINGTON, 1991), com foco na assimetria de informações (AKERLOF, 1970), uma das principais causas dos conflitos de interesse nas relações entre o agente e o principal, e nesse sentido, como forma de reduzir essa assimetria informacional, identificamos a governança corporativa no setor público (MELLO, 2006). Além disso, abordou-se a teoria dos incentivos (BARNARD, 1938; AGHION e TIROLE, 1997; LAFFONT e MANTIMORT, 2002), como um dos principais instrumentos imprescindíveis para minimizar os conflitos de agência.

\subsubsection{Pesquisa Documental}

A pesquisa documental (ZANELLA, 2009) envolveu a investigação em documentos e dados da instituição, tais como: relatórios, dados registrados no Sistema de Patrimônio (SIPAT) e, principalmente, dados oriundos do inventário patrimonial anual. O objetivo principal do inventário patrimonial anual é por em evidência a situação plena e real dos bens móveis ao final de cada exercício. Ou seja, permite que o setor de patrimônio possa confrontar os dados constantes no SIPAT com o que está realmente in loco para se obter o controle de todo o acervo da instituição na consecução dos objetivos institucionais. O inventário patrimonial deve conter a lista completa dos bens patrimoniais de cada centro de custo (unidades da FUB, acadêmicas ou administrativas), mesmo os que não foram encontrados, 
assim como todas as informações de cada bem, como: localização dentro do centro de custo, agente patrimonial responsável pelo respectivo bem, estado de conservação do bem (SANTOS, 2012).

Nesse sentido, ao se estudar o Inventário Patrimonial Anual, oriundos dos centros de custo da FUB, compreendeu-se a dificuldade que o setor de patrimônio tem ao tentar obter o levantamento físico e o controle desses bens móveis, e nesse sentido, foram analisadas as principais divergências e irregularidades mencionadas por estes centros de custos. Essa documentação foi necessária para compreender quais os principais problemas enfrentados pelos agentes patrimoniais na guarda e conservação de suas cargas patrimoniais e identificar soluções para estes problemas.

Vale salientar que o objetivo da análise dos inventários patrimoniais é de identificar e analisar as principais inconformidades dos bens patrimoniais correlacionando-a com a hipótese perseguida de que existe baixa cooperação dos agentes patrimoniais. Sendo assim, não é o foco dessa análise realizar um estudo quantitativo completo das divergências e irregularidades dos bens móveis da FUB, pois tal proposta seria de difícil realização no prazo de tempo limitado da pesquisa, como também em razão da grande amplitude de bens móveis pertencentes à FUB.

O emprego dos questionários, a pesquisa bibliográfica e documental é imprescindível para analisar qualitativamente (GÜNTHER, 2006) os conflitos de agência entre a FUB e os seus agentes patrimoniais no âmbito da sua gestão de bens móveis patrimoniais e, consequentemente, definir as estratégias necessárias para dirimir esses conflitos, a serem adotadas tanto pelo Agente quanto pelo Principal. Assim sendo, com base nos resultados da 
pesquisa elaborou-se uma série de sugestões e incentivos que a FUB poderá utilizar para que ocorra a diminuição desses conflitos, tanto a nível institucional quanto comportamental.

\section{RESULTADOS E DISCUSSÃO}

\section{1 - Análise e Interpretação dos Dados Coletados no Inventário Patrimonial Anual da UnB de 2013}

Faz-se necessário termos uma percepção, do universo onde o Inventário Patrimonial Descentralizado Anual tem sido trabalhado em termo de números, para que se tenha uma noção da dimensão do acervo patrimonial administrado pela UnB. Atualmente, constam no Sistema de Gestão de Patrimônio (SIPAT) cerca de 287.208 bens móveis sob responsabilidade de 3.416 agentes patrimoniais, entre docentes e servidores técnicoadministrativos, nos 4 campi (Darcy Ribeiro, Planaltina, Gama e Ceilândia) da Universidade de Brasília (UnB).

Segundo a Resolução do Decanato de Administração nº 0023/2013 e conforme visto no referencial teórico, os inventários físicos devem possuir obrigatoriamente a relação de carga patrimonial de cada agente da unidade, por local, contendo todos os bens localizados no inventário, assinada pelo seu respectivo agente ou no seu impedimento, pelo Titular da unidade e o relatório analítico por centro de custo, contendo todos os bens pertencentes ao acervo da unidade, devidamente assinado pela subcomissão de inventário. Tanto a relação de carga, quanto o relatório analítico pode ser obtido e impresso pelo Sistema de Gestão Patrimonial (SIPAT) da UnB. Além dos documentos obrigatórios citados acima, costuma-se seguir em anexo no inventário, uma lista de divergências, caso exista irregularidades, inconformidades e assimetria nas informações dos bens inventariados. Essas listas de 
divergências foram de extrema importância para o presente trabalho, pois através dele compreenderam-se os principais problemas relatados pelas subcomissões de inventário e que são enfrentados pelos agentes patrimoniais na guarda e conservação de suas cargas patrimoniais correlacionando-o com a hipótese pretendida de que existe baixa cooperação dos agentes patrimoniais com a Universidade, com o objetivo de elaborar uma série de incentivos e soluções para tentar minorar estes problemas. Vale ressaltar, que esses problemas quando não solucionados impedem uma melhor eficiência, planejamento, avaliação, controle e transparência na gestão do acervo patrimonial de bens móveis da FUB.

Serão relatados a seguir alguns procedimentos e responsabilidades inerentes ao inventário patrimonial descentralizado dos bens móveis da UnB no ano de 2013, determinado pelo Decanato da Administração (DAF), com o fim de disciplinar e uniformizar a realização dos mesmos. Essas normas e procedimentos estão previstas na Resolução do Decanato de Administração $n^{\circ}$ 0023/2013. Inicialmente, a Diretoria de Gestão de Materiais (DGM) juntamente com a Coordenação de Patrimônio (PAT) enviou a todos os centros de custo da UnB, em 28 de agosto de 2013, a Circular $n^{\circ}$ 003/2013 junto com a Resolução $n^{\circ}$ 0023/2013(DAF), solicitando a todas as unidades que indicassem os membros das subcomissões do inventário patrimonial anual até o dia 20 de setembro de 2013. Essas indicações deveriam ser respondidas através de memorando, assinado pelo titular dos centros de custo, e encaminhado, por UnBDoc, (sistema interno da UnB para cadastramento de documentos) ao DAF via DGM. Nesse sentido, para a realização do inventário em tempo hábil à prestação de contas físico-financeira de 2013 e manutenção do controle de acervo patrimonial, foi elaborado pelo DAF, um cronograma de atividades do Inventário Patrimonial, vide anexo A. 
Dos 127 centros de custo da UnB informados via memorando sobre a necessidade de realização do Inventário Patrimonial Descentralizado de Bens Móveis do ano de 2013, 74 centros de custo enviaram ao setor de patrimônio os seus respectivos Inventários Patrimoniais de Bens Móveis do ano de 2013, conforme quadro abaixo:

Quadro 2: Centros de Custo que enviaram inventário ao Setor de Patrimônio em 2013

\begin{tabular}{|l|l|l|l|l|l|}
\hline ALM/PAT & CPAI & DPO & FAU & ICS & PJU \\
\hline AUD & CPCE & DPP & FCI & IED & PPB \\
\hline BOT & CRAD & DRU & FED & IGD & PPGA \\
\hline CAEP & DAC & DSA & FEF & IHD & PST \\
\hline CEAD & DAF & DSC & FGA & ILD & SAA \\
\hline CEAM & DAIA & ECL & FMD & INTERFOCO & SME/CEU \\
\hline CEFTRU & DAN & ECO & FTD & IPOL & SOC \\
\hline CEPLAN & DATAUNB & EDU & FUP & IQD & TEL \\
\hline CEPPAC & DCF & ENE & GEM & IREL & ZOO \\
\hline CESPE & DDS & EST & GRE & MAT & \\
\hline CFS & DEA & FAC & HIS & MUS & \\
\hline CIFMC & DGP & FACE & HUB & PCL & \\
\hline CME & DOR & FAL & IBD & PED & \\
\hline FOn & & & & & \\
\hline
\end{tabular}

Fonte: Inventários Patrimoniais de Bens Móveis da UnB do ano 2013

Assim sendo, 53 centros de custo não enviaram o Inventário ao setor de patrimônio e por isso, os mesmos não foram analisados. Dentre os 74 Inventários Patrimoniais Descentralizados de Bens Móveis do ano de 2013 analisados, 64 possuíam alguma divergência, inconformidade, irregularidade relatada no Inventário. Assim sendo, 10 Inventários Patrimoniais não continham nenhuma lista de divergências, nesse sentido, nesses 
centros de custos, não havia nenhuma inconformidade patrimonial a ser relatada. Vale ressaltar, que no que diz respeito aos Inventários Patrimoniais Descentralizados de Bens Móveis do ano de 2013, o presente estudo não observou in loco a veracidade das informações fornecidas pelos Inventários, assim, existe a possibilidade de haver alguma inconformidade nos 10 centros de custos que não informaram as suas divergências, portanto as informações apresentadas neste estudo estão de acordo com as fornecidas pelos centros de custo através dos Inventários assinados pelas suas respectivas subcomissões.

Quadro 3: Centros de Custo que enviaram inventário, acompanhado de lista de divergência, ao Setor de Patrimônio em 2013.

\begin{tabular}{|l|l|l|l|l|l|l|l|}
\hline AUD & CESPE & DAF & DPO & EST & FTD & IGD & PJU \\
\hline BOT & CFS & DAIA & DPP & FAC & FUP & IHD & PPB \\
\hline CAEP & CIFMC & DAM & DRU & FAU & GEM & ILD & PST \\
\hline CEAD & CME & DATAUNB & DSC & FCI & GRE & IPOL & SAA \\
\hline CEAM & CPAI & DCF & ECL & FED & HIS & MAT & SME/CEU \\
\hline CEFTRU & CPCE & DDS & ECO & FEF & IBD & MUS & SOC \\
\hline CEPLAN & CRAD & DEA & EDU & FGA & ICS & PCL & TEL \\
\hline CEPPAC & DAC & DGP & ENE & FMD & IED & PED & ZOO \\
\hline
\end{tabular}

Fonte: Inventários Patrimoniais de Bens Móveis da UnB do ano 2013

O Quadro 3 acima apresenta a relação dos centros de custo que enviaram as informações e assinalaram as respectivas divergências entre os inventários físicos e os registros no SIPAT.

Já o Quadro 4 abaixo, por sua vez, apresenta a relação dos centros de custo que enviaram as informações nas quais não foram apresentadas nenhuma divergência entre os inventários físicos e os registros no SIPAT. 
Quadro 4: Centros de Custo que enviaram inventário, sem lista de divergência, ao Setor de Patrimônio em 2013.

\begin{tabular}{|l|l|}
\hline ALM/PAT & HUB \\
\hline DOR & INTERFOCO \\
\hline DAS & IQD \\
\hline FACE & IREL \\
\hline FAL & PPGA \\
\hline
\end{tabular}

Fonte: Inventários Patrimoniais de Bens Móveis da UnB do ano 2013

Dos 64 centros de custo que enviaram as suas listas de divergências anexas ao Inventário, elencamos as dez inconformidades comumente encontradas, como sendo as seguintes:

1) bens não localizados;

2) solicitações de baixa e recolhimento de bens em desuso;

3) solicitações de transferências de cargas patrimoniais entre agentes patrimoniais;

4) ausência de assinatura dos agentes patrimoniais nas suas respectivas relações de cargas patrimoniais;

5) bens registrados no SIPAT, mas sem a plaqueta de identificação anexada;

6) bens que não estão cadastrados no SIPAT;

7) bens cadastrados no SIPAT com características equivocadas;

8) agentes patrimoniais com alocação equivocada no SIPAT;

9) bens registrados no SIPAT com alocação errada;

10) bens em processo de transferência de cargas patrimoniais entre agentes patrimoniais.

Para melhor entender o porquê de selecionar essas dez inconformidades, elaborou-se o Quadro 5 abaixo com o significado e a importância dessas informações na prática. 
QUADRO 5: As 10 principais divergências e irregularidades relatadas nos inventários patrimoniais da UnB em 2013

\begin{tabular}{|c|c|}
\hline DIVERGÊNCIA & SIGNIFICADO E IMPORTÂNCIA \\
\hline $\begin{array}{l}\text { Bens não } \\
\text { localizados }\end{array}$ & $\begin{array}{l}\text { Indica que os bens foram movimentados fisicamente ou foram } \\
\text { extraviados e não houve atualização no SIPAT. Assim sendo, esses } \\
\text { bens constam no SIPAT em um determinado local, mas que in loco } \\
\text { não estão presentes. Essa falta de transparência contribui para uma } \\
\text { baixa eficiência no planejamento e alocação dos bens móveis, além de } \\
\text { gerar transtornos legais aos responsáveis patrimoniais. }\end{array}$ \\
\hline $\begin{array}{l}\text { Solicitações de } \\
\text { baixa e } \\
\text { recolhimento de } \\
\text { bens em desuso }\end{array}$ & $\begin{array}{l}\text { Indica que existem bens que não possuem utilidade, mas que ainda } \\
\text { estão nos centros de custo e constam no SIPAT como ativos (úteis). } \\
\text { Essa situação impede que seja feita uma melhor alocação de recursos } \\
\text { públicos pela instituição }\end{array}$ \\
\hline $\begin{array}{l}\text { Solicitações de } \\
\text { transferências de } \\
\text { cargas } \\
\text { patrimoniais } \\
\text { entre agentes } \\
\text { patrimoniais }\end{array}$ & $\begin{array}{l}\text { Indica que existem bens que não estão mais sob a responsabilidade de } \\
\text { um determinado agente patrimonial precisando de atualização no } \\
\text { SIPAT para a mudança de agente patrimonial ou/e local. Essa } \\
\text { atualização permite um maior controle do bem móvel pela instituição, } \\
\text { e consequentemente melhor distribuição dos bens. }\end{array}$ \\
\hline $\begin{array}{l}\text { Ausência de } \\
\text { assinatura dos } \\
\text { agentes } \\
\text { patrimoniais nas } \\
\text { suas respectivas } \\
\text { relações de cargas } \\
\text { patrimoniais }\end{array}$ & $\begin{array}{l}\text { Indica que o servidor responsável pela carga patrimonial não pôde ou } \\
\text { não quis se responsabilizar pelos os itens constantes na sua carga } \\
\text { patrimonial e por isso não quis ou não pôde assiná-la. Essa falta de } \\
\text { assinatura impede a evidenciação das responsabilidades dos órgãos e } \\
\text { responsáveis pela guarda dos bens móveis patrimoniais. }\end{array}$ \\
\hline $\begin{array}{l}\text { Bens registrados } \\
\text { no SIPAT, mas } \\
\text { sem a plaqueta de }\end{array}$ & $\begin{array}{l}\text { Indica que existem bens que não pode ser identificados } \\
\text { adequadamente, visto que a sua plaqueta de identificação foi } \\
\text { extraviada. Dificultando a localização desses bens pelos agentes }\end{array}$ \\
\hline
\end{tabular}




\begin{tabular}{|c|c|}
\hline $\begin{array}{l}\text { identificação } \\
\text { anexada }\end{array}$ & $\begin{array}{l}\text { patrimoniais responsáveis, e consequentemente, impedindo a guarda e } \\
\text { conservação dos mesmos. }\end{array}$ \\
\hline $\begin{array}{l}\text { Bens que não estão } \\
\text { cadastrados no } \\
\text { SIPAT }\end{array}$ & $\begin{array}{l}\text { Indica que existem bens sendo utilizados nos centros de custos, mas } \\
\text { que não foram registrados pelo setor de patrimônio no SIPAT, ou seja, } \\
\text { não consta no acervo de registro patrimonial da instituição. Essa } \\
\text { ausência de registro impede o controle patrimonial. O setor de } \\
\text { patrimônio não delegará um agente patrimonial responsável pela } \\
\text { guarda e conservação desse bem, impedindo também o adequado } \\
\text { envio desse bem para reparos e manutenções. }\end{array}$ \\
\hline $\begin{array}{l}\text { Bens cadastrados } \\
\text { no SIPAT com } \\
\text { características } \\
\text { equivocadas }\end{array}$ & $\begin{array}{l}\text { Indica que determinados bens foram cadastrados equivocadamente nas } \\
\text { suas características no SIPAT. Ex: cadeira sem braço, mas cadastrado } \\
\text { como se tivesse braço. Dificultando a adequada localização dos bens. }\end{array}$ \\
\hline $\begin{array}{l}\text { Agentes } \\
\text { patrimoniais com } \\
\text { alocação } \\
\text { equivocada no } \\
\text { SIPAT }\end{array}$ & $\begin{array}{l}\text { Indica que alguns agentes patrimoniais mudaram o seu centro de custo } \\
\text { e não comunicaram ao setor de patrimônio para atualização no SIPAT. } \\
\text { Gerando erros nas alocações dos bens móveis para esses agentes } \\
\text { patrimoniais. }\end{array}$ \\
\hline $\begin{array}{l}\text { Bens registrados } \\
\text { no SIPAT com } \\
\text { alocação errada }\end{array}$ & $\begin{array}{l}\text { Indica que existem bens alocados de forma incorreta nos centros de } \\
\text { custos. Ou seja, estão cadastrados no SIPAT em um local, mas estão } \\
\text { sendo utilizados em outro local. Contribuindo para que a instituição } \\
\text { planeje a distribuição dos bens móveis de forma equivocada. }\end{array}$ \\
\hline $\begin{array}{l}\text { Bens em processo } \\
\text { de transferência } \\
\text { de cargas } \\
\text { patrimoniais }\end{array}$ & $\begin{array}{l}\text { Indica que há transferência parcial ou total de bens entre determinados } \\
\text { agentes, e que ainda não foi efetivada por falta de assinaturas dos } \\
\text { respectivos agentes nos termos de transferência. Dificultando o } \\
\text { controle patrimonial e impedindo o bom andamento dos processos de } \\
\text { exoneração, redistribuição, e aposentadoria dos agentes patrimoniais } \\
\text { que ainda possuem a carga patrimonial. }\end{array}$ \\
\hline
\end{tabular}

Fonte: Dados do autor

Analisaremos, a seguir, cada uma dessas 10 divergências/irregularidades relatadas pelos centros de custo através dos Inventários, dando ênfase, posteriormente, as possíveis 
soluções que podem ser adotadas pelos agentes patrimoniais e pela UnB para minimizar esses problemas.

Com relação aos bens não localizados, 22 centros de custo relataram 0 desaparecimento de bens móveis, a relação desses centros de custo consta no apêndice $\mathrm{B}$. $\mathrm{O}$ extravio de um bem móvel por furto, roubo, depredação, movimentações não autorizadas, deverá de imediato ser comunicado, pelo responsável da Carga Patrimonial à Coordenação de Patrimônio, observando-se os diversos procedimentos necessários.

No caso de parecer da UnB pela reposição ou recuperação do bem pelo responsabilizado, homologado pela autoridade competente da unidade, este bem deverá ser devidamente depreciado pelo setor de patrimônio e o processo deverá ser encaminhado determinando a reposição do bem pelo agente responsável. $\mathrm{O}$ bem reposto pelo responsabilizado ficará no depósito patrimonial da FUB, em local e em condições adequadas, até que se encerrem os procedimentos administrativos para os registros de controle no PAT. Existe ainda a possibilidade de baixa patrimonial sem ressarcimento, devidamente homologado pela autoridade competente, depois de esgotadas todas as possibilidades de apuração de responsabilidades.

Diversos fatores contribuem para o desaparecimento de bens móveis na UnB, vejamos alguns: o fácil acesso de pessoas as dependências da Universidade; a grandiosidade física da UnB; ausência de controle e monitoramento dos bens sob responsabilidade dos agentes patrimoniais; ausência da aplicação de responsabilização legal sobre os agentes patrimoniais e aos centros de custo; inexperiência da subcomissão ou dos agentes patrimoniais responsáveis por inventariar os bens etc. 
Quanto à segunda divergência, 10 centros de custos, vide apêndice $\mathrm{B}$, relataram a necessidade de baixa e recolhimento de bens em desuso pelo setor de patrimônio. A baixa compreende a retirada do bem do acervo patrimonial realizada pela coordenação de patrimônio e o seu recolhimento é realizado pelo setor de depósito da UnB vinculado à coordenação de patrimônio. O recolhimento é geralmente solicitado pelo responsável pelo bem nos casos de inservibilidade, desnecessidade ou excedente e ocorre quando o bem não está sendo utilizado devidamente pelo seu respectivo centro de custo.

Posteriormente, caso o bem ainda possa ser utilizado, este poderá ser redistribuído para outro setor que possa julgá-lo em condições de uso. A maioria dessas solicitações de baixa e recolhimento pelos centros de custo veio ocorrendo ao longo de todo o ano de 2013, sendo novamente solicitados nos Inventários anuais, portanto, o setor de patrimônio juntamente com o depósito em muitos casos não deu cumprimento a essas solicitações.

Um dos principais motivos para o não atendimento dessas solicitações foi à falta de transporte e pessoal para fazer o recolhimento dos bens e ausência de um espaço físico apropriado no depósito, pois o mesmo se encontrava saturado de bens móveis. Muitos desses bens móveis, após o recolhimento podem ter os seguintes destinos: leilão, doação, permuta, cessão ou outra modalidade. A acumulação de bens móveis exige uma enorme quantidade de depósitos para guardar esses bens, gerando gastos desnecessários, caso a administração de patrimônio não possua um bom gerenciamento sobre os bens recolhidos e destinados a posterior alienação. 
No que diz respeito às solicitações de transferências entre os agentes patrimoniais, foram observadas em 21 centos de custos, vide apêndice B, e quando realizadas adequadamente não trazem nenhum transtorno à gestão patrimonial. Essas transferências de responsabilidades podem ocorrer com mudança ou não do local onde o bem foi registrado, ou seja, com ou sem movimentação do bem. Infelizmente, ocorre que muitas dessas transferências não são realmente efetivadas pela coordenação de patrimônio por ausência de concordância dos agentes patrimoniais em aceitar a carga patrimonial transferida, assim muitos agentes patrimoniais mudam o seu setor de trabalho e continuam vinculados ao setor antigo por não ter conseguido transferir as suas respectivas cargas patrimoniais. Essa situação acaba gerando transtornos futuros a esses agentes ao solicitarem as suas aposentadorias, redistribuições ou exonerações, e também gera um impacto no controle do bem móvel pela administração patrimonial, dificultando um planejamento adequado na alocação dos bens móveis pela instituição.

A quarta questão analisada é a ausência de assinatura dos relatórios de carga patrimonial pelos agentes patrimoniais. Conforme dito ao longo deste trabalho, o Inventário Patrimonial Anual Descentralizado de Bens Móveis é composto basicamente de 2 peças: relatórios individuais de cargas patrimoniais dos agentes patrimoniais, por local e o relatório analítico dos bens. Sendo assim, os relatórios individuais quando assinados, confirmam a informação contida neles, ou seja, os agentes patrimoniais quando deixam de assinar, estão se negando a confirmar a posse e responsabilidade sobre os bens móveis, mesmo que os bens já estejam registrados nas suas respectivas cargas patrimoniais.

No inventário de 2013, observou-se, conforme apêndice B, que 46 centros de custo possuíam ausência de assinatura em alguns dos seus relatórios de cargas patrimoniais. Os 
agentes patrimoniais se recusam a assinar os relatórios de carga patrimonial por diversos motivos, o principal dele é a não localização de todos os bens constantes nas suas respectivas cargas patrimoniais nos locais registrados. Outro motivo bastante comum para a não assinatura é a ausência física do agente patrimonial no período que está sendo realizado o inventário nos centros de custo, principalmente por motivo de viagens e doenças. Nesses casos, o titular das unidades, tais como Diretores, possuem um permissivo legal para assinar as relações de cargas em substituição ao agente patrimonial ausente, mas isso muitas vezes não ocorre.

Outra inconformidade relatada por 08 centros de custo nos Inventários foi à existência de bens sem a plaqueta de identificação anexada. A plaqueta deve ser afixada, preferencialmente, logo após o processo de tombamento, em local bem visível e de fácil acesso. A plaqueta utilizada atualmente é confeccionada a partir de uma lâmina de alumínio com cola de alta resistência na parte posterior, é padronizada para toda a Instituição e identificada pelo termo FUB - PATRIMÔNIO, seguido por um número, além de um código de barras.

Há, porém, outros tipos de plaquetas de patrimônio, com desenho diferente, também padronizada para toda a FUB, mas que era usada nos tombamentos mais antigos. Infelizmente, com o mau uso dos bens móveis, essas plaquetas são extraviadas, dificultando a localização e o controle dos bens por parte dos agentes patrimoniais e do setor de patrimônio. Nesse sentido, é imprescindível o cuidado e o zelo com os bens pelos seus respectivos responsáveis, diminuindo a possibilidade de extravio dessas plaquetas. 
A sexta inconformidade, registrada em 09 centros de custo (vide apêndice B), é a existência de bens que estavam sendo utilizados nas unidades, mas que não estavam registrados no SIPAT. Esses bens de alguma maneira foram para os centros de custo sem antes serem registrados no SIPAT.

Os bens móveis são adquiridos de diversas formas: compra, doação, permuta, cessão, fabricação própria, comodato. O recebimento do bem móvel é de competência do setor de patrimônio, porém, nem sempre isso acontece, haja vista que muitos bens não são adquiridos pela própria instituição e sim por pesquisadores, coordenadores, professores, chefes, diretores, entre outros que acabam adquirindo esses bens móveis por meio de projetos e os mesmos não informam ao setor de patrimônio para que sejam registrados para adequada alocação do responsável e do local onde o bem será utilizado.

Nesse sentido, esses bens acabam não fazendo parte do acervo de bens da Universidade, dificultando o processo de controle patrimonial, além disso, impedem que o setor de patrimônio registre um agente patrimonial responsável pela guarda e conservação desse bem, prejudicando também o adequado envio desse bem para reparos e manutenções.

Somente 01 centro de custo, conforme apêndice B, informou a existência de bens com especificação equivocada, ou seja, estavam registrados no SIPAT com determinadas características, mas que na prática, não possuía, ex: cadeira registrada com braço, mas que não possuía braços. O registro das características do bem móvel, na maioria das vezes, é feito a partir das informações contidas na nota fiscal, e essa nota fiscal pode ter sido emitida erroneamente ou o funcionário responsável pelo registro no SIPAT se equivocou ao registrar 
corretamente o bem. Essa situação dificulta o adequado levantamento físico dos bens através dos Inventários Anuais.

Outra questão relatada por 02 centros de custo nos inventários, vide apêndice $\mathrm{B}$, foi à presença de agentes patrimoniais com alocação equivocada no SIPAT, ou seja, determinados agentes patrimoniais mudaram o seu centro de custo e não comunicaram ao setor de patrimônio para atualização no SIPAT, e muitos deles ainda possuem carga patrimonial nos centros de custo onde trabalhavam. Assim, se os bens desses agentes forem localizados, estes deverão ser transferidos para um novo agente pertencente ao centro de custo; caso os bens não sejam localizados, o centro de custo deverá entrar em contato com o agente patrimonial para que o mesmo tome as providências cabíveis com relação aos bens desaparecidos.

Faz-se necessário realizar essa atualização para que não ocorram divergências nas alocações dos bens móveis, prejudicando o controle patrimonial dos bens móveis. Essa situação frequentemente ocorre, porque muitos agentes patrimoniais não conseguem transferir os bens dos seus antigos centros de custo para nenhum outro agente patrimonial.

Apenas um centro de custo relatou a presença de bens alocados em local errado, ou seja, estão cadastrados no SIPAT em um local, mas que na prática estão sendo utilizados em outro local. Essa situação contribui para um inexato planejamento e distribuição dos bens móveis pela instituição, além disso, prejudica a sua correta localização.

E por último, temos 32 centros de custos, conforme apêndice $\mathrm{B}$, que relataram a presença de bens móveis em movimentação, ou seja, essas unidades possuem bens que estão em processo de transferência para outros agentes patrimoniais, mas que por falta de assinatura 
dessas transferências, ainda não foram efetivadas no SIPAT. Mais uma vez, ocorrendo ausência de colaboração entre os agentes patrimoniais no que concerne a posse e guarda dos bens móveis que estão sob seu uso. Essa situação também leva a uma dificultando no controle patrimonial pela universidade, além de impedir o bom andamento dos processos de exoneração, redistribuição, e aposentadoria dos agentes patrimoniais que ainda possuem a carga patrimonial.

Contrastando a teoria da agência com os dados consolidados do Inventário Patrimonial Anual pelas unidades da FUB de 2013, podemos perceber conforme visto acima, diversos comportamentos indesejáveis por parte dos agentes, assimetria de informações e dificuldades de controle e monitoramento. Além disso, verificaram-se também diversos problemas na administração patrimonial causada pela má gestão institucional. Nesse sentido, muitos bens foram extraviados e não foram localizados no local em que está registrado no SIPAT; há uma grande divergência de informações entre o que está registrado no SIPAT e o que realmente está presente in loco; os agentes patrimoniais que detêm as cargas patrimoniais, ou até mesmo os órgãos institucionais responsáveis por aplicar essa ordem ou fazer cumprir as normas, não correspondem às expectativas instituídas e planejadas do setor de patrimônio; são frequentes os problemas encontrados nas movimentações de cargas patrimoniais entre os agentes, dentre eles, observamos principalmente a falta de interesse dos agentes patrimoniais em assinar os documentos de movimentação de carga patrimonial, impedindo a efetivação dessa movimentação; há uma carência de pessoal, principalmente treinado e motivado, nas últimas contratações o setor de patrimônio não foi contemplado de acordo com suas necessidades e demanda de trabalho; o fato de o setor de patrimônio não ser considerado um serviço-fim da Instituição e sim um serviço-meio, acaba por deixá-lo em segundo plano, prejudicando o andamento das suas atividades; a área de administração patrimonial carece de dados e 
informações institucionais atualizados; as leis, normas e regulamentos acabam não sendo divulgadas por toda a instituição, e consequentemente não são cumpridas, em razão de seu desconhecimento; falta de espaço físico suficiente para gerir adequadamente os bens móveis recolhidos; a gestão patrimonial necessita desenvolver um processo de gestão eficiente e confiável para que os agentes patrimoniais possam sentir-se tranquilos quanto a sua responsabilidade no controle de seus bens móveis.

\section{2 - Análise e interpretação dos dados fornecidos pelos questionários aplicados aos agentes patrimoniais da $\mathrm{UnB}$}

Apresentam-se, a seguir, os dados consolidados das respostas individuais obtidas com a aplicação de questionários aos agentes patrimoniais da FUB, assim como os resultados das análises qualitativa e quantitativa dos dados coletados. Os questionários foram aplicados nos diversos centros de custo da UnB, conforme apêndice A, pela via presencial e, também, mediante solicitação por email, como recurso via internet, utilizou-se às ferramentas do Google docs de automatização de questionários para pesquisa. Foram aplicados um total de 1.200 questionários, dos quais foram entregues e validados 105 questionários pelos agentes patrimoniais, tanto servidores técnico-administrativos quanto docentes, da UnB.

No que diz respeito ao tamanho da amostra pesquisada, pode-se afirmar que o total de 105 questionários respondidos foi mais que suficiente para analisar o universo de 3.416 agentes patrimoniais que possuem carga patrimonial na UnB. Ao se calcular a amostra mínima necessária para o universo pesquisado, utilizou-se uma margem de erro de $10 \%$, um nível de confiança de $90 \%$ e uma taxa de heterogeneidade de 50\%, assim, com esses valores seriam necessários à análise de no mínimo 67 questionários, portanto a pesquisa utilizou um total de 105 questionários, ficando acima do mínimo necessário. O resultado esperado 
utilizando a fórmula abaixo também poderá ser obtido por meio de uma calculadora online presente na página eletrônica da netquest ${ }^{3}$ (LEVIN, 1987; TRIOLA, 1999; STEVENSON, 2001; COSTA NETO, 2000).

Segundo Levine, Berenson e Stephan (2000), vejamos a seguir, com detalhes, a fórmula necessária para se descobrir qual a amostra mínima necessária:

$$
\mathrm{n}=\frac{N \cdot Z^{2} \cdot p \cdot(1-p)}{(N-1) \cdot \mathrm{e}^{2}+Z^{2} \cdot p \cdot(1-p)}
$$

Onde:

$\mathbf{n}=$ O tamanho da amostra que queremos calcular

$\mathbf{N}=$ Tamanho do universo (3.416 agentes patrimoniais)

$\mathbf{Z}=$ É o desvio do valor médio que aceitamos para alcançar o nível de confiança desejado. Em função do nível de confiança que buscamos, usaremos um valor determinado que é dado pela forma da distribuição de Gauss. O ideal é utilizar entre 90 e 100\%. Os valores mais frequentes são: Nível de confiança 90\% -> Z=1,645 (utilizou-se na pesquisa esse nível de confiança, ou seja, 90\%); Nível de confiança 95\% -> Z=1,96 e Nível de confiança 99\% -> Z=2,575

$\mathbf{e}=$ É a margem de erro máximo que eu quero admitir. O ideal é utilizar entre 0-10\%. (utilizou-se a margem de erro de 10\%)

$\mathbf{p}=$ É a proporção que esperamos encontrar, ou seja, o nível de heterogeneidade (utilizou-se o valor de 50\%). Como regra geral, esse valor é utilizado, porque não se tinha nenhuma informação sobre o valor que esperava encontrar.

\footnotetext{
${ }^{3}$ Disponível em: < http://www.netquest.com/br/painel/qualidade-calculadora-amostras.html >. Acessado em: 07 nov. 2015
} 
No que tange a validade das perguntas do questionário, utilizou-se o coeficiente alpha de cronbach, por meio do software estatístico IBM SPSS, versão 20.0.0. Esse coeficiente, que varia entre 0 e 1 , permite analisar em que grau os itens do questionário estão interrelacionados, através do número de itens do questionário e da proporção da variância total da amostra (HAYES, 2001; LEDESMA, 2004). O coeficiente alpha de cronbach encontrado na presente pesquisa foi de 0,6 . Apesar dos estudos científicos que versam sobre a aplicação do coeficiente de cronbach nas diversas áreas da pesquisa científica, percebe-se que ainda não existe um consenso entre os estudiosos no que tange a interpretação da confiabilidade de um questionário obtida a partir do valor deste coeficiente. Não há um valor mínimo definido para o coeficiente alfa de cronbach ser aceito como bom, mas segundo Pestana e Cageiro (2005), o valor de 0,6 é o mínimo aceitável. Assim, pode-se afirmar que os resultados encontrados indicam que o instrumento utilizado apresenta aceitável confiabilidade interna quando se considera como indicador o alfa de cronbach. Existem, entretanto, pesquisadores que utilizam o alfa de cronbach sem fazerem nenhuma citação a um mínimo necessário (XEXÉO, 2001; MIGUEL e SALOMI, 2004; MATO e VEIGA, 2000). É importante frisar que esta análise estatística não substitui o papel do pesquisador em avaliar a conveniência de uma pergunta que avalie a percepção de um entrevistado acerca de algum aspecto relevante.

Inicialmente, analisamos o perfil dos entrevistados com relação ao gênero, lotação, idade, tempo de serviço na universidade, período de tempo como agente patrimonial. Esses dados descritivos são necessários para identificar o perfil do agente patrimonial. Com relação ao gênero pesquisado, observou-se que $56,19 \%$ dos entrevistados são homens enquanto 43,81\% são mulheres, conforme se observa no Gráfico 1 abaixo:

\section{Gráfico 1: Perfil dos entrevistados por gênero}




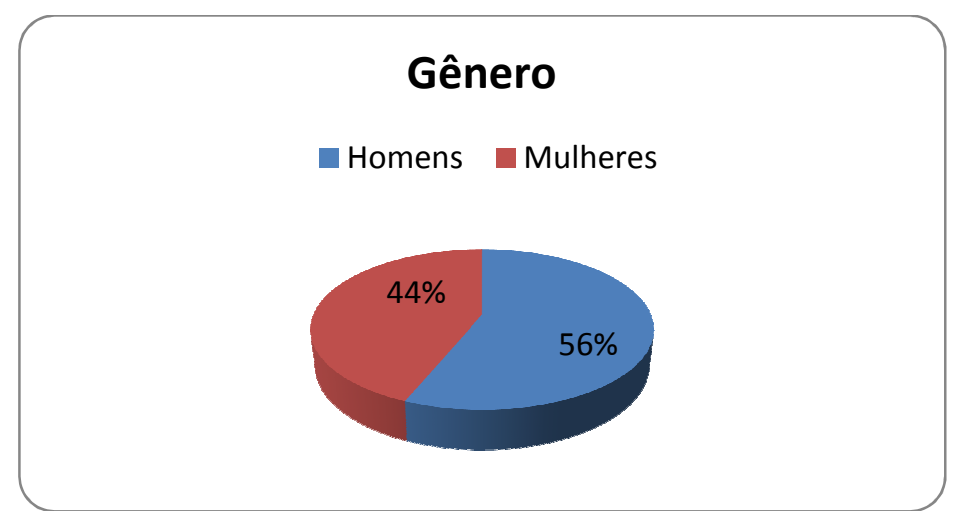

Fonte: dados da pesquisa

No que diz respeito à idade, do total de agentes patrimoniais pesquisados: $3,81 \%$ possuíam entre 18 e 30 anos; 31,43\% entre 31 e 43 anos; 43,81\% entre 44 e 56 anos; e, por fim, 20,95\% entre 57 e 70 anos, idade máxima para permanência no serviço público, segundo as regras de aposentadoria compulsória atual. Vide Gráfico 2 abaixo:

\section{Gráfico 2: Perfil dos entrevistados por idade}

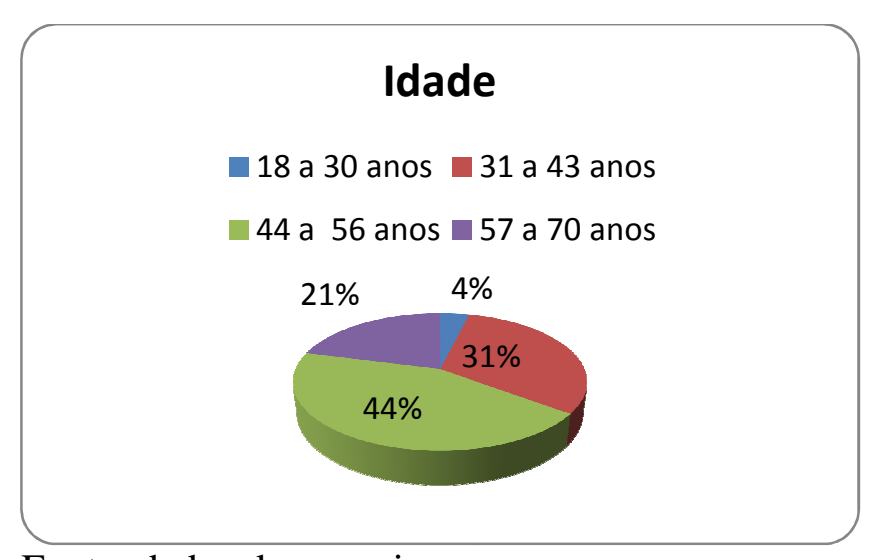

Fonte: dados da pesquisa

No aspecto relativo ao tempo de serviço, em anos, na UnB, pode-se perceber que $8,57 \%$ dos agentes patrimoniais possuíam até 03 anos de efetivo exercício prestado à UnB. Ou seja, trata-se de servidores em início de carreira e ainda em período de prova do estágio probatório. $44,76 \%$ agentes patrimoniais tinham entre 4 a 15 anos. $24,76 \%$ deles, entre 16 a 27 anos. Por fim, 21,90\% possuem mais de 28 anos de serviço. Confira-se a esse respeito o gráfico 3 a seguir: 
Gráfico 3: Perfil dos entrevistados por tempo de serviço

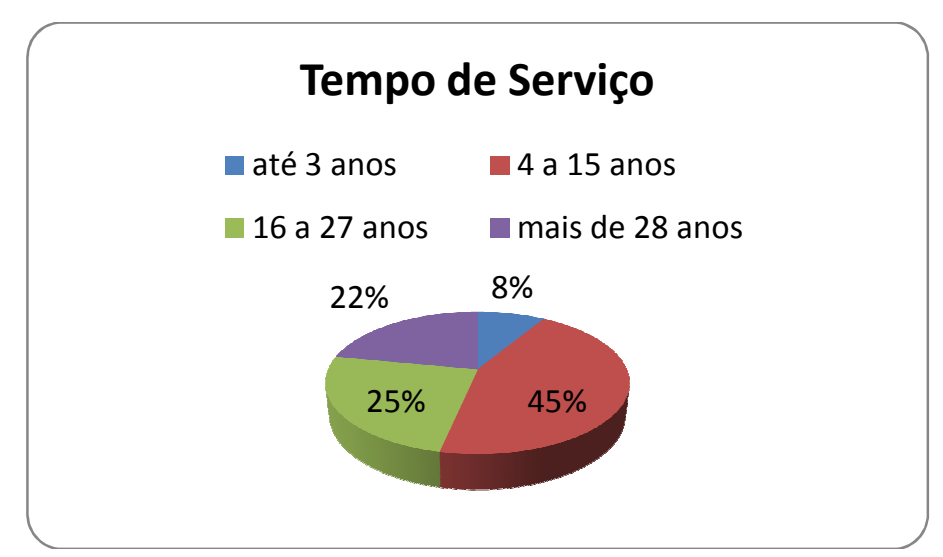

Fonte: dados da pesquisa

O tempo na função de agente patrimonial, em anos, também foi objeto da pesquisa. Com base nos dados coletados, percebeu-se que $58,10 \%$ dos agentes patrimoniais, a maioria, possuíam entre 0 a 10 anos nessa qualidade. Já 24,76\% deles tinham entre 11 e 22 anos detendo carga sob sua responsabilidade. $15,24 \%$, entre 23 a 34 anos. E, por fim, apenas 1,90\% acima de 35 anos na função como agente patrimonial. Confira-se no gráfico 4:

Gráfico 4: Perfil dos entrevistados por tempo no exercício da função de agente patrimonial

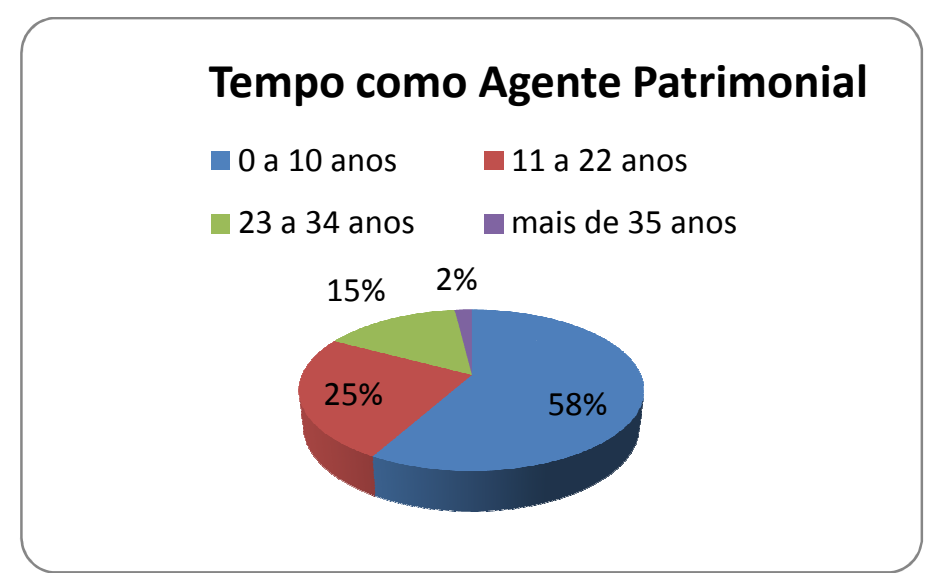

Fonte: dados da pesquisa 
No que diz respeito à lotação, observou-se que os agentes patrimoniais entrevistados estavam lotados em 48 centros de custo diferentes, conforme Quadro 6 adiante. Por fim, além dos dados descritivos apresentados acima, o questionário continha uma pergunta no qual foi solicitado ao agente patrimonial que fizesse uma auto avaliação, quanto ao seu desempenho no exercício da função de agente patrimonial da FUB. Eles foram, então, instados a escolher numa escala entre 0 e 10, a nota que melhor representa sua dedicação sobre a gestão de sua carga patrimonial. Do total de agentes patrimoniais pesquisados, 9,52\% deles indicaram uma nota que variava entre 0 a $3 ; 16,19 \%$ dos agentes reputaram sua conduta como equivalente a um desempenho entre 4 a $6 ; 28 \%$ indicaram uma nota entre 7 e 8 e outros 46,67\% agentes deram-se uma nota 9 ou 10. Apresenta-se a seguir o quadro 6 e o gráfico 5 com as informações relatadas acima. Confira-se:

Quadro 6: Centros de Custos Pesquisados

\begin{tabular}{|l|l|l|l|l|l|}
\hline ALM & DGM & FACE & FUP & IP & PAT \\
\hline CCA & DIN & FCE & GEA & IPOL & PCL \\
\hline CEL & DPA & FCI & HUB & IQD & PED \\
\hline CEPLAN & DPO & FEF & IBD & IREL & PRC \\
\hline CIC & ECL & FGA & ICS & LET & PST \\
\hline CPD & ECO & FIT & IDA & MCA & REITORIA \\
\hline DAN & ENC & FM & IGD & MUS & SAA \\
\hline DCO & ENE & FS & IH & NUT & VIS \\
\hline
\end{tabular}

Fonte: dados da pesquisa 
Gráfico 5: Notas auto atribuídas pelos agentes em avaliação de sua própria atuação como agente patrimonial

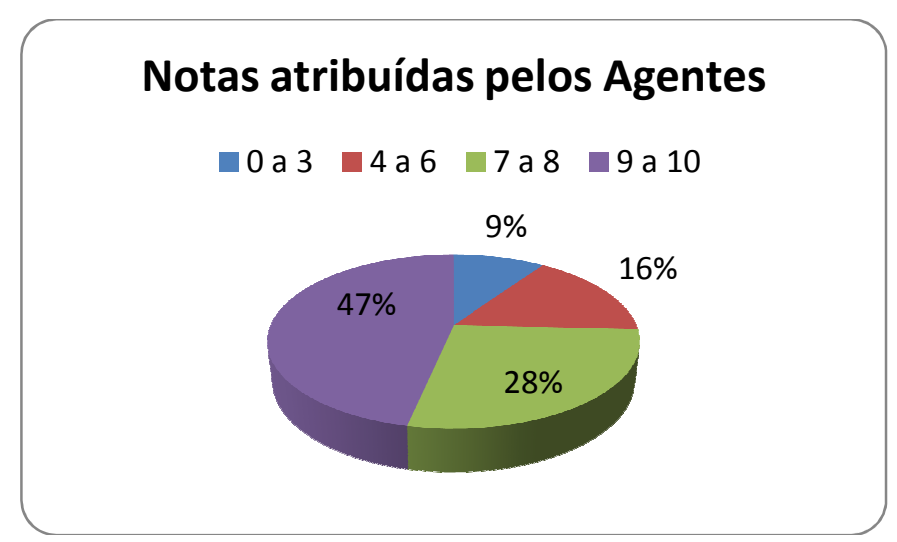

Fonte: dados da pesquisa

Analisaremos a seguir, as 18 perguntas fechadas que indicavam o grau de concordância dos agentes patrimoniais sobre a gestão patrimonial da UnB. Nessas perguntas, utilizou-se uma escala de classificação do tipo Likert de 5 pontos, sendo: nota 1 se o agente patrimonial discorda totalmente da afirmação apresentada; nota 2 se discorda parcialmente da afirmação apresentada; nota 3 se não concorda e nem discorda da afirmação apresentada; nota 4 se concorda parcialmente com a afirmação apresentada e nota 5 se concorda totalmente com a afirmação apresentada. Nesse sentido, considerando-se que os itens do questionário aplicado têm formato de 5 pontos, sendo 3 o ponto médio, durante a apresentação dos resultados, além do porcentual de concordância encontrado, apresenta-se também a média e o desvio padrão obtido em cada uma das questões.

Portanto, pode-se afirmar que um ponto médio acima de 3 indica concordância com o enunciado da pergunta apresentada pelo questionário. Ao revés, um ponto médio abaixo de 3 sugere discordância da pergunta apresentada no questionário.

Vejamos a seguir cada pergunta separadamente. A primeira pergunta versa sobre a elaboração e distribuição de um manual entre os agentes patrimoniais, um manual que 
fornecesse informações básicas relativas à gestão patrimonial dos seus bens móveis. Essa pergunta foi elaborada com o intuito de obter dos agentes patrimoniais a informação da necessidade de obter orientações sobre a gestão patrimonial na UnB refletindo no grau de responsabilidade sobre a carga patrimonial. De acordo com as respostas, conforme tabela 1 abaixo, podemos perceber que quase $90 \%$ dos agentes patrimoniais concordam total e parcialmente com a necessidade de se obter informações relativas à gestão patrimonial. Essa concordância demonstra falta de informações dos agentes patrimoniais sobre a administração patrimonial.

Nesse sentido, faz-se necessário que a UnB elabore e distribua um manual com as principais informações sobre melhor gerir a gestão patrimonial pelos agentes patrimoniais, pois vemos que na universidade falta uma política de disseminação do conhecimento institucional. Ressalta-se, ainda, que no caso de novos servidores, esse manual poderia ser entregue pelo setor pessoal no momento da posse do servidor, e para os servidores que já foram empossados, poderia ser enviando via e-mail.

\section{Tabela 1: Dados da questão 1 do questionário de entrevista}

Questão 1: A FUB deveria elaborar e distribuir entre os agentes patrimoniais um manual que fornecesse informações básicas relativas à gestão patrimonial dos seus bens móveis.

\begin{tabular}{c|l|l|l|l|l|l}
\hline $\begin{array}{c}\text { Nota 1 } \\
\text { Discorda } \\
\text { totalmente }\end{array}$ & $\begin{array}{l}\text { Nota 2 } \\
\text { Discorda } \\
\text { parcialmente }\end{array}$ & $\begin{array}{c}\text { Nota 3 } \\
\text { Não } \\
\text { concorda } \\
\text { e nem } \\
\text { discorda }\end{array}$ & $\begin{array}{l}\text { Nota 4 } \\
\text { Concorda } \\
\text { parcialmente }\end{array}$ & $\begin{array}{l}\text { Nota 5 } \\
\text { Concorda } \\
\text { totalmente }\end{array}$ & Média & $\begin{array}{l}\text { Desvio } \\
\text { Padrão }\end{array}$ \\
\hline $\mathbf{1 , 9 0 \%}$ & $\mathbf{4 , 7 6 \%}$ & $\mathbf{4 , 7 6 \%}$ & $\mathbf{2 7 , 6 2 \%}$ & $\mathbf{6 0 , 9 5 \%}$ & $\mathbf{4 , 4 1}$ & $\mathbf{0 , 9 3}$ \\
\hline
\end{tabular}

Fonte: dados da pesquisa 
Na pergunta 2, que versa sobre a necessidade de a UnB ministrar cursos/palestras para divulgar a importância e responsabilidade dos agentes patrimoniais, percebeu-se que $68,57 \%$ concordam parcial ou totalmente com essa assertiva. Essa situação significa que, mais uma vez, há uma grande necessidade de orientação aos agentes patrimoniais para que possam agir de modo mais responsável sobre a sua carga patrimonial. Pode-se perceber que, na prática, o conhecimento sobre a gestão patrimonial está acumulado no setor de patrimônio, estando retido nas pessoas que trabalham no local. Assim, fazem-se necessários cursos e palestras que facilitem a troca de informações e experiências entre os servidores que trabalham diariamente com a gestão patrimonial e os agentes patrimoniais. Infelizmente, existe pouca literatura a respeito da gestão patrimonial, e o conhecimento prático oriundo dos servidores que trabalham no setor de patrimônio, acaba sendo levando com eles quando os mesmos se aposentam ou pedem exoneração.

Tabela 2: Dados da questão 2 do questionário de entrevista

Questão 2: A FUB deveria ministrar cursos/palestras aos agentes patrimoniais no intuito de divulgar a importância e responsabilidade da atividade patrimonial dos agentes.

\begin{tabular}{c|l|l|l|l|l|l}
\hline $\begin{array}{c}\text { Nota 1 } \\
\text { Discorda } \\
\text { totalmente }\end{array}$ & $\begin{array}{l}\text { Nota 2 } \\
\text { Discorda } \\
\text { parcialmente }\end{array}$ & $\begin{array}{c}\text { Nota 3 } \\
\text { Não } \\
\text { concorda } \\
\text { e nem } \\
\text { discorda }\end{array}$ & $\begin{array}{l}\text { Nota 4 } \\
\text { Concorda } \\
\text { parcialmente }\end{array}$ & $\begin{array}{l}\text { Nota 5 } \\
\text { Concorda } \\
\text { totalmente }\end{array}$ & Média & $\begin{array}{l}\text { Desvio } \\
\text { Padrão }\end{array}$ \\
\hline $\mathbf{3 , 8 1 \%}$ & $\mathbf{1 4 , 2 9 \%}$ & $\mathbf{1 3 , 3 3 \%}$ & $\mathbf{2 8 , 5 7 \%}$ & $\mathbf{4 0 , 0 0 \%}$ & $\mathbf{3 , 8 7}$ & $\mathbf{1 , 2 0}$ \\
\hline
\end{tabular}

Fonte: dados da pesquisa 
$\mathrm{Na}$ pergunta 3, que versa sobre a divulgação das normas/regulamentos da gestão patrimonial, percebe-se, mais uma vez, a necessidade de a Universidade divulgar aos agentes patrimoniais todas as informações relevantes à gestão patrimonial para se evitar problemas relacionados à falta de responsabilidade sobre as cargas patrimoniais. Assim sendo, pode se observar conforme a tabela 3 a seguir, que quase $83 \%$ discordam total ou parcialmente que as normas e os regulamentos sobre responsabilidade patrimonial são amplamente divulgados pela universidade. Nesse sentido, para que os agentes patrimoniais exerçam uma boa gestão dos bens que estão sob sua responsabilidade, faz-se necessário que os mesmos possuam um conhecimento mínimo necessário para agir com um melhor gerenciamento e controle.

\section{Tabela 3: Dados da questão 3 do questionário de entrevista}

Questão 3: As normas e regulamentos que versam sobre responsabilidade e gestão patrimonial são amplamente divulgadas pela FUB.

\begin{tabular}{c|l|l|l|l|l|l}
\hline $\begin{array}{c}\text { Nota 1 } \\
\text { Discorda } \\
\text { totalmente }\end{array}$ & $\begin{array}{l}\text { Nota 2 } \\
\text { Discorda } \\
\text { parcialmente }\end{array}$ & $\begin{array}{c}\text { Nota 3 } \\
\text { Não } \\
\text { concorda } \\
\text { e nem } \\
\text { discorda }\end{array}$ & $\begin{array}{l}\text { Nota 4 } \\
\text { Concorda } \\
\text { parcialmente }\end{array}$ & $\begin{array}{l}\text { Nota 5 } \\
\text { Concorda } \\
\text { totalmente }\end{array}$ & Média & $\begin{array}{l}\text { Desvio } \\
\text { Padrão }\end{array}$ \\
\hline $\mathbf{4 6 , 6 7 \%}$ & $\mathbf{3 6 , 1 9 \%}$ & $\mathbf{9 , 5 2 \%}$ & $\mathbf{6 , 6 7 \%}$ & $\mathbf{0 , 9 5 \%}$ & $\mathbf{1 , 7 9}$ & $\mathbf{0 , 9 4}$ \\
\hline
\end{tabular}

Fonte: dados da pesquisa

Nessas 3 primeiras perguntas supra, podemos perceber a importância de disseminar as políticas patrimoniais por toda a instituição, refletindo diretamente na forma de como os agentes patrimoniais irão exercer o controle, conservação e a guarda dos materiais permanentes.

Antes de analisarmos as respostas referentes à pergunta 4 , relembremos que conforme visto no referencial teórico, o agente patrimonial poderá ser qualquer servidor técnicoadministrativo ou docente, não sendo necessário nenhuma característica específica. Nesse 
contexto, a pergunta 4 questiona se a FUB deveria analisar critérios específicos que identificassem qual seria o melhor perfil profissional para a escolha do agente patrimonial, como será visto na análise das questões 4 e 5 adiante. Conforme a tabela 4 abaixo, a média encontrada para essa pergunta foi 3,41, indicando concordância com a pergunta apresentada. Nesse sentido, podemos ver que a maioria dos agentes patrimoniais concorda que a universidade deveria utilizar critérios específicos na escolha do agente patrimonial. Nesse sentido, seria interessante que a UnB identificasse o perfil mais adequado para que um servidor possa ser agente patrimonial, e com base nele, sugerir aos centros de custo que os servidores mais indicados para serem agentes patrimoniais.

\section{Tabela 4: Dados da questão 4 do questionário de entrevista}

Questão 4: A FUB deveria analisar critérios específicos que identificasse qual seria o melhor perfil profissional para a escolha do agente patrimonial.

\begin{tabular}{c|l|l|l|l|l|l}
\hline $\begin{array}{c}\text { Nota 1 } \\
\text { Discorda } \\
\text { totalmente }\end{array}$ & $\begin{array}{l}\text { Nota 2 } \\
\text { Discorda } \\
\text { parcialmente }\end{array}$ & $\begin{array}{c}\text { Nota 3 } \\
\text { Não } \\
\text { concorda } \\
\text { e nem } \\
\text { discorda }\end{array}$ & $\begin{array}{l}\text { Nota 4 } \\
\text { Concorda } \\
\text { parcialmente }\end{array}$ & $\begin{array}{l}\text { Nota 5 } \\
\text { Concorda } \\
\text { totalmente }\end{array}$ & Média & $\begin{array}{l}\text { Desvio } \\
\text { Padrão }\end{array}$ \\
\hline $\mathbf{8 , 5 7 \%}$ & $\mathbf{1 5 , 2 4 \%}$ & $\mathbf{2 0 , 9 5 \%}$ & $\mathbf{3 7 , 1 4 \%}$ & $\mathbf{1 8 , 1 0 \%}$ & $\mathbf{3 , 4 1}$ & $\mathbf{1 , 2 0}$ \\
\hline
\end{tabular}

Fonte: dados da pesquisa

Ainda com relação ao aspecto do perfil de agentes patrimoniais, elaborou-se na pergunta 5 uma afirmativa que versava sobre os servidores possuírem perfil para serem agentes patrimoniais. E constatou-se nas respostas uma média de 2,74. Ou seja, uma média abaixo de 3 significando discordância da pergunta apresentada. Essa pergunta corrobora a pergunta anterior. Portanto, mais uma vez percebe-se que segundo os próprios agentes patrimoniais, os mesmos não possuem perfil adequado para a função, necessitando que a universidade estude e descubra qual o perfil mais adequado para indicar os servidores na função de agente patrimonial. 
Tabela 5: Dados da questão 5 do questionário de entrevista

Questão 5: Em geral, os servidores (técnicos e docentes) possuem perfis adequados para serem agentes patrimoniais.

\begin{tabular}{c|l|l|l|l|l|l}
\hline $\begin{array}{c}\text { Nota 1 } \\
\text { Discorda } \\
\text { totalmente }\end{array}$ & $\begin{array}{l}\text { Nota 2 } \\
\text { Discorda } \\
\text { parcialmente }\end{array}$ & $\begin{array}{c}\text { Nota 3 } \\
\text { Não } \\
\text { concorda } \\
\text { e nem } \\
\text { discorda }\end{array}$ & $\begin{array}{l}\text { Nota 4 } \\
\text { Concorda } \\
\text { parcialmente }\end{array}$ & $\begin{array}{l}\text { Nota 5 } \\
\text { Concorda } \\
\text { totalmente }\end{array}$ & Média & $\begin{array}{l}\text { Desvio } \\
\text { Padrão }\end{array}$ \\
\hline $\mathbf{2 0 , 9 5 \%}$ & $\mathbf{2 7 , 6 2 \%}$ & $\mathbf{1 6 , 1 9 \%}$ & $\mathbf{2 6 , 6 7 \%}$ & $\mathbf{8 , 5 7 \%}$ & $\mathbf{2 , 7 4}$ & $\mathbf{1 , 2 9}$ \\
\hline
\end{tabular}

Fonte: dados da pesquisa

A pergunta 6 foi elaborada com o intuito de extrair dos agentes patrimoniais sua opinião sobre a eficiência e confiabilidade proporcionadas aos agentes patrimoniais pela gestão patrimonial da UnB, a fim de se aferir se há tranquilidade no controle e monitoramento de seus bens móveis. Mais de $92 \%$ das respostas concordam total e parcialmente que a UnB deveria fornecer uma gestão patrimonial mais eficiente e confiável refletindo diretamente na responsabilidade do controle e monitoramento das cargas patrimoniais pelos agentes patrimoniais.

Tabela 6: Dados da questão 6 do questionário de entrevista

Questão 6: A gestão patrimonial da FUB deveria desenvolver um processo de gestão eficiente e confiável para que os agentes patrimoniais pudessem sentir-se tranquilo quanto a sua responsabilidade no controle e monitoramento de seus bens móveis.

\begin{tabular}{c|l|l|l|l|l|l}
\hline $\begin{array}{c}\text { Nota 1 } \\
\text { Discorda } \\
\text { totalmente }\end{array}$ & $\begin{array}{l}\text { Nota 2 } \\
\text { Discorda } \\
\text { parcialmente }\end{array}$ & $\begin{array}{c}\text { Nota 3 } \\
\text { Não } \\
\text { concorda } \\
\text { e nem } \\
\text { discorda }\end{array}$ & $\begin{array}{l}\text { Nota 4 } \\
\text { Concorda } \\
\text { parcialmente }\end{array}$ & $\begin{array}{l}\text { Nota 5 } \\
\text { Concorda } \\
\text { totalmente }\end{array}$ & Média & $\begin{array}{l}\text { Desvio } \\
\text { Padrão }\end{array}$ \\
\hline $\mathbf{0 , 9 5 \%}$ & $\mathbf{2 , 8 6 \%}$ & $\mathbf{3 , 8 1 \%}$ & $\mathbf{3 8 , 1 0 \%}$ & $\mathbf{5 4 , 2 9 \%}$ & $\mathbf{4 , 4 2}$ & $\mathbf{0 , 7 8}$ \\
\hline
\end{tabular}

Fonte: dados da pesquisa 
Existem diversas formas de se obter um controle patrimonial mais eficiente por parte da UnB, que serão discutidas mais adiantes, principalmente, através de um controle patrimonial informatizado mais eficiente; atualização e divulgação patrimonial periódica.

Ainda correlacionada com o tema anterior, a pergunta 7 diz respeito à eficiência da UnB na sua gestão patrimonial, e questiona aos agentes patrimoniais se a UnB é suficientemente eficiente para solucionar os problemas oriundos da falta de controle e monitoramento dos bens móveis. Nesse sentido, conforme tabela 7 abaixo, 70,47\% discordaram, total ou parcialmente, com uma média de 2,01. Portanto, mais uma vez podemos perceber a fragilidade do setor de patrimônio em exercer uma gestão patrimonial adequada às necessidades dos agentes patrimoniais. Na prática, percebe-se existe uma enorme dificuldade de trabalhar com poucos funcionários, visto que o patrimônio tem diversas atribuições e existe uma extensa quantidade de bens. Além desses problemas, a UnB ainda conta com um sistema de controle informatizado pouco eficiente e obsoleto.

A despeito da existência de um sistema informatizado, persiste a necessidade da realização de vários atos manuais. Os agentes patrimoniais necessitam imprimir, assinar e enviar fisicamente diversos documentos relacionados à sua gestão patrimonial. Todo esse processo poderia se tornar mais ágil e menos burocrático, se a exemplo de outras instituições públicas se existisse também na UnB um controle patrimonial informatizado mais eficiente, principalmente através de senhas pessoais, minimizando todo o trâmite burocrático que envolve a gestão patrimonial na UnB.

\section{Tabela 7: Dados da questão 7 do questionário de entrevista}

Questão 7: A gestão patrimonial da FUB é eficiente para solucionar os problemas oriundos da falta de controle e monitoramento dos bens móveis sob responsabilidade dos agentes 


\begin{tabular}{c|l|l|l|l|l|l}
\hline patrimoniais. & Nota 2 \\
\hline $\begin{array}{c}\text { Nota 1 } \\
\text { totalmente }\end{array}$ & $\begin{array}{l}\text { Discorda } \\
\text { parcialmente }\end{array}$ & $\begin{array}{c}\text { Não } \\
\text { concorda } \\
\text { e nem } \\
\text { discorda }\end{array}$ & $\begin{array}{l}\text { Nota 4 } \\
\text { Concorda } \\
\text { parcialmente }\end{array}$ & $\begin{array}{l}\text { Nota 5 } \\
\text { Concorda } \\
\text { totalmente }\end{array}$ & Média & $\begin{array}{l}\text { Desvio } \\
\text { Padrão }\end{array}$ \\
\hline $\mathbf{3 7 , 1 4 \%}$ & $\mathbf{3 3 , 3 3 \%}$ & $\mathbf{2 1 , 9 0 \%}$ & $\mathbf{6 , 6 7 \%}$ & $\mathbf{0 , 9 5 \%}$ & $\mathbf{2 , 0 1}$ & $\mathbf{0 , 9 8}$ \\
\hline
\end{tabular}

Fonte: dados da pesquisa

Na pergunta 8 tratou-se de perquirir aos agentes patrimoniais se os mesmos achavam eficazes os incentivos negativos presentes nas normas internas da Universidade, subsidiada pela lei 8.112/1990, especialmente nos casos de bens não localizados que implica na não emissão de certidão negativa de débitos patrimoniais. Certidão essa cuja não obtenção impossibilita o servidor público de obter aposentadoria, redistribuição e exoneração e leva ao ressarcimento ao erário. Podemos perceber, com base nas respostas da tabela 8 adiante, que cerca de $56 \%$ das respostas não concordavam e nem discordavam da pergunta, 33\% discordavam total ou parcialmente, com uma média de 2,67.

Esses números indicam que a maioria dos agentes patrimoniais não soube responder se as sanções exercidas pela Universidade são realmente eficazes. Ademais, cerca de 1/3 das respostas discordavam da eficácia dessas punições. Nesse sentido, pode-se perceber a necessidade da implementação de incentivos positivos, tais como: incentivos financeiros e não financeiros aos agentes patrimoniais como forma de estimular os agentes patrimoniais a terem mais responsabilidade sobre as suas cargas patrimoniais e consequentemente um maior controle patrimonial.

Tabela 8: Dados da questão 8 do questionário de entrevista

Questão 8: Têm sido eficazes as punições aos agentes patrimoniais exercidas atualmente pela FUB para os bens móveis não localizados, tais como: ressarcimento ao erário; não obtenção de certidão negativa de débitos patrimoniais nos processos de aposentadoria, redistribuição e 


\begin{tabular}{c|l|l|l|l|l|l}
\hline exoneração. & Nota 2 \\
$\begin{array}{c}\text { Nota 1 } \\
\text { Discorda } \\
\text { totalmente }\end{array}$ & $\begin{array}{l}\text { Discorda } \\
\text { parcialmente }\end{array}$ & $\begin{array}{c}\text { Nota 3 } \\
\text { Não } \\
\text { concorda } \\
\text { e nem } \\
\text { discorda }\end{array}$ & $\begin{array}{l}\text { Nota 4 } \\
\text { Concorda } \\
\text { parcialmente }\end{array}$ & $\begin{array}{l}\text { Nota 5 } \\
\text { Concorda } \\
\text { totalmente }\end{array}$ & Média & $\begin{array}{l}\text { Desvio } \\
\text { Padrão }\end{array}$ \\
\hline $\mathbf{1 6 , 1 9 \%}$ & $\mathbf{1 7 , 1 4 \%}$ & $\mathbf{5 6 , 1 9 \%}$ & $\mathbf{4 , 7 6 \%}$ & $\mathbf{5 , 7 1 \%}$ & $\mathbf{2 , 6 7}$ & $\mathbf{1 , 0 0}$ \\
\hline
\end{tabular}

Fonte: dados da pesquisa

As 3 próximas perguntas tratam diretamente sobre os incentivos que a UnB poderia fornecer aos seus agentes patrimoniais. Na pergunta 09, questionou-se se haveria vantagem em reduzir a carga horária de trabalho para que fosse utilizado o tempo excedente na gestão de patrimonial dos bens móveis sob responsabilidade dos agentes patrimoniais. Conforme tabela 9 a seguir, cerca de 59\%, ou seja, a maioria respondeu que discordavam total ou parcialmente dessa vantagem e somente $22,86 \%$ acreditavam na existência de vantagem em se reduzir a carga horária de trabalho para utilizar o tempo remanescente nas atividades de gestão patrimonial. Nesse sentido, percebeu-se que a maioria dos agentes patrimoniais acredita que não há a necessidade desse tipo de incentivo para melhorar a sua responsabilidade sobre os bens patrimoniais.

\section{Tabela 9: Dados da questão 9 do questionário de entrevista}

Questão 9: Haveria vantagem em reduzir carga horária de trabalho para utilizar esse tempo excedente na administração dos bens patrimoniais sob responsabilidade dos agentes patrimoniais.

\begin{tabular}{c|l|l|l|l|l|l}
\hline $\begin{array}{c}\text { Nota 1 } \\
\text { Discorda } \\
\text { totalmente }\end{array}$ & $\begin{array}{l}\text { Nota 2 } \\
\text { Discorda } \\
\text { parcialmente }\end{array}$ & $\begin{array}{c}\text { Nota 3 } \\
\text { Não } \\
\text { concorda } \\
\text { e nem } \\
\text { discorda }\end{array}$ & $\begin{array}{l}\text { Nota 4 } \\
\text { Concorda } \\
\text { parcialmente }\end{array}$ & $\begin{array}{l}\text { Nota 5 } \\
\text { Concorda } \\
\text { totalmente }\end{array}$ & Média & $\begin{array}{l}\text { Desvio } \\
\text { Padrão }\end{array}$ \\
\hline $\mathbf{3 3 , 3 3 \%}$ & $\mathbf{2 5 , 7 1 \%}$ & $\mathbf{1 8 , 1 0 \%}$ & $\mathbf{1 6 , 1 9 \%}$ & $\mathbf{6 , 6 7 \%}$ & $\mathbf{2 , 3 7}$ & $\mathbf{1 , 2 8}$ \\
\hline
\end{tabular}

Fonte: dados da pesquisa 
$\mathrm{Na}$ pergunta 10, questionou-se a vantagem de haver outro incentivo positivo, os benefícios monetários. Conforme tabela 10 , observou-se que 56,19\% discordam total ou parcialmente de receber benefícios monetários para terem mais controle e monitoramento sobre as suas cargas patrimoniais e somente $24,76 \%$ acreditam que a FUB deveria fornecer esse incentivo. Diante dessas respostas, supõe-se que essa discordância é resultado dos baixos incentivos monetários existentes nas funções gratificadoras atualmente existentes no âmbito da UnB. Para os entrevistados, essa contraprestação não remunera a responsabilidade relativa às cargas sob sua responsabilidade. $\mathrm{O}$ resultado dessa pergunta também pode supor que nenhum incentivo financeiro seria capaz de estimular os agentes patrimoniais a terem mais responsabilidade sobre suas cargas.

Tabela 10: Dados da questão 10 do questionário de entrevista

Questão 10: A FUB deveria fornecer benefícios monetários para incentivar os agentes patrimoniais a terem mais controle e monitoramento sob suas cargas patrimoniais.

\begin{tabular}{c|l|l|l|l|l|l}
\hline $\begin{array}{c}\text { Nota 1 } \\
\text { Discorda } \\
\text { totalmente }\end{array}$ & $\begin{array}{l}\text { Nota } 2 \\
\text { Discorda } \\
\text { parcialmente }\end{array}$ & $\begin{array}{c}\text { Nota 3 } \\
\text { Não } \\
\text { concorda } \\
\text { e nem } \\
\text { discorda }\end{array}$ & $\begin{array}{l}\text { Nota 4 } \\
\text { Concorda } \\
\text { parcialmente }\end{array}$ & $\begin{array}{l}\text { Nota 5 } \\
\text { Concorda } \\
\text { totalmente }\end{array}$ & Média & $\begin{array}{l}\text { Desvio } \\
\text { Padrão }\end{array}$ \\
\hline $\mathbf{3 4 , 2 9 \%}$ & $\mathbf{2 1 , 9 0 \%}$ & $\mathbf{1 9 , 0 5 \%}$ & $\mathbf{8 , 5 7 \%}$ & $\mathbf{1 6 , 1 9 \%}$ & $\mathbf{2 , 5 0}$ & $\mathbf{1 , 4 5}$ \\
\hline
\end{tabular}

Fonte: dados da pesquisa

Na pergunta 11, questionou-se a necessidade da UnB fornecer aos seus agentes patrimoniais benefícios não financeiros, tais como: prêmios de qualidade, prestígio, reconhecimento, para incentivá-los a terem mais controle e monitoramento sob a carga que está sob sua responsabilidade. Conforme tabela $11,47,62 \%$ concordam total ou parcialmente com a instituição desse tipo de incentivo; e 39,05\% discordam total ou parcialmente com esse tipo de incentivo, com uma média de 3. Portanto, podemos perceber que ao contrário da 
pergunta anterior em que se tratava de incentivos financeiros, os agentes patrimoniais demonstraram uma preferência por incentivos não financeiros.

\section{Tabela 11: Dados da questão 11 do questionário de entrevista}

Questão 11: A FUB deveria fornecer benefícios não monetários para incentivar os agentes patrimoniais a terem mais controle e monitoramento sob suas cargas, tais como: prêmios de qualidade; poder de decisão, prestígio, reconhecimento, etc.

\begin{tabular}{c|l|l|l|l|l|l}
\hline $\begin{array}{c}\text { Nota 1 } \\
\text { totalmente }\end{array}$ & $\begin{array}{l}\text { Nota 2 } \\
\text { Discorda } \\
\text { parcialmente }\end{array}$ & $\begin{array}{c}\text { Nota 3 } \\
\text { Não } \\
\text { concorda } \\
\text { e nem } \\
\text { discorda }\end{array}$ & $\begin{array}{l}\text { Nota 4 } \\
\text { Concorda } \\
\text { parcialmente }\end{array}$ & $\begin{array}{l}\text { Nota 5 } \\
\text { Concorda } \\
\text { totalmente }\end{array}$ & Média & $\begin{array}{l}\text { Desvio } \\
\text { Padrão }\end{array}$ \\
\hline $\mathbf{2 2 , 8 6 \%}$ & $\mathbf{1 6 , 1 9 \%}$ & $\mathbf{1 3 , 3 3 \%}$ & $\mathbf{3 3 , 3 3 \%}$ & $\mathbf{1 4 , 2 9 \%}$ & $\mathbf{3}$ & $\mathbf{1 , 4 1}$ \\
\hline
\end{tabular}

Fonte: dados da pesquisa

Questionou-se na pergunta 12 se o fácil acesso de pessoas aos Campi da UnB dificultava o controle pelos agentes patrimoniais dos bens patrimoniais sob sua responsabilidade. Conforme tabela 12 abaixo, a média obtida das respostas ficou acima de 4 , onde $76,19 \%$ concordam total ou parcialmente com a pergunta. Na prática, observa-se que o fácil acesso de pessoas as dependências da Universidade facilita o desaparecimento dos bens móveis, principalmente, diante da imensidão física da UnB, sendo assim, faz-se necessário um apoio eficaz do setor de segurança da Universidade.

\section{Tabela 12: Dados da questão 12 do questionário de entrevista}

Questão 12: O fácil acesso de pessoas a FUB dificulta o controle dos bens patrimoniais sob a responsabilidade dos agentes patrimoniais.

\begin{tabular}{c|l|l|l|l|l|l}
\hline $\begin{array}{c}\text { Nota 1 } \\
\text { Discorda } \\
\text { totalmente }\end{array}$ & $\begin{array}{l}\text { Nota 2 } \\
\text { Discorda } \\
\text { parcialmente }\end{array}$ & $\begin{array}{c}\text { Nota 3 } \\
\text { Não } \\
\text { concorda } \\
\text { e nem } \\
\text { discorda }\end{array}$ & $\begin{array}{l}\text { Nota 4 } \\
\text { Concorda } \\
\text { parcialmente }\end{array}$ & $\begin{array}{l}\text { Nota 5 } \\
\text { Concorda } \\
\text { totalmente }\end{array}$ & Média & $\begin{array}{l}\text { Desvio } \\
\text { Padrão }\end{array}$ \\
\hline $\mathbf{4 , 7 6 \%}$ & $\mathbf{9 , 5 2 \%}$ & $\mathbf{9 , 5 2 \%}$ & $\mathbf{3 2 , 3 8 \%}$ & $\mathbf{4 3 , 8 1 \%}$ & $\mathbf{4 , 0 1}$ & $\mathbf{1 , 1 6}$ \\
\hline
\end{tabular}

Fonte: dados da pesquisa 
Com relação ao número de bens móveis sob responsabilidade dos agentes patrimoniais, questionou-se na pergunta 13 a relação entre o número de bens e o controle desses bens pelos agentes patrimoniais. Assim sendo, percebeu-se, conforme tabela 13 adiante, que $73,34 \%$ concordam total ou parcialmente com a afirmativa de que quanto maior o número de bens móveis pior é o controle desses bens sob responsabilidade dos agentes patrimoniais.

Nesse sentido, pode-se supor que uma das formas de aumentar o controle e consequentemente a responsabilidade do agente patrimonial no trato com as suas respectivas cargas patrimoniais seria diminuir o número de bens móveis que estão sob sua responsabilidade, assim, quanto menor a carga patrimonial mais fácil ficaria o controle dessa carga pelos agentes patrimoniais.

Tabela 13: Dados da questão 13 do questionário de entrevista

Questão 13: Quanto maior o número de bens móveis, pior é o controle desses bens sob responsabilidade dos agentes patrimoniais.

\begin{tabular}{|c|c|c|c|c|c|c|}
\hline Nota 1 & Nota 2 & Nota 3 & Nota 4 & Nota 5 & Média & Desvio \\
\hline $\begin{array}{l}\text { Discorda } \\
\text { totalmente }\end{array}$ & $\begin{array}{l}\text { Discorda } \\
\text { parcialmente }\end{array}$ & $\begin{array}{c}\text { Não } \\
\text { concorda } \\
\text { e nem } \\
\text { discorda }\end{array}$ & $\begin{array}{l}\text { Concorda } \\
\text { parcialmente }\end{array}$ & $\begin{array}{l}\text { Concorda } \\
\text { totalmente }\end{array}$ & & Padrão \\
\hline $3,81 \%$ & $8,57 \%$ & $14,29 \%$ & $38,10 \%$ & $35,24 \%$ & 3,92 & 1,09 \\
\hline
\end{tabular}

Fonte: dados da pesquisa

Na pergunta 14, que também versa sobre a característica física da carga, questionou-se aos agentes patrimoniais se quanto maior o valor dos bens móveis maior seria o controle e monitoramento desses bens. Assim, conforme tabela 14 a seguir, percebeu-se que das 5 notas possíveis, a que teve maior nota foi à nota 3 , que significa que o respondente não concorda e nem discorda da afirmativa com $28,57 \%$, mas na média total obteve-se o valor 3,10, enquanto que $38,10 \%$ concordando total ou parcialmente com a afirmativa. Nesse sentido, pode-se 
concluir que o valor dos bens móveis tem pouca influência no controle e monitoramento dos bens sob responsabilidade dos agentes.

Tabela 14: Dados da questão 14 do questionário de entrevista

Questão 14: Quanto maior o valor dos bens móveis, maior é o controle e monitoramento desses bens sob responsabilidade dos agentes patrimoniais.

\begin{tabular}{c|l|l|l|l|l|l}
\hline $\begin{array}{c}\text { Nota 1 } \\
\text { Discorda } \\
\text { totalmente }\end{array}$ & $\begin{array}{l}\text { Nota } 2 \\
\text { Discorda } \\
\text { parcialmente }\end{array}$ & $\begin{array}{c}\text { Nota 3 } \\
\text { Não } \\
\text { concorda } \\
\text { e nem } \\
\text { discorda }\end{array}$ & $\begin{array}{l}\text { Nota 4 } \\
\text { Concorda } \\
\text { parcialmente }\end{array}$ & $\begin{array}{l}\text { Nota 5 } \\
\text { Concorda } \\
\text { totalmente }\end{array}$ & Média & $\begin{array}{l}\text { Desvio } \\
\text { Padrão }\end{array}$ \\
\hline $\mathbf{1 0 , 4 8 \%}$ & $\mathbf{2 2 , 8 6 \%}$ & $\mathbf{2 8 , 5 7 \%}$ & $\mathbf{2 2 , 8 6 \%}$ & $\mathbf{1 5 , 2 4 \%}$ & $\mathbf{3 , 1 0}$ & $\mathbf{1 , 2 2}$ \\
\hline
\end{tabular}

Fonte: dados da pesquisa

A pergunta 15 questiona ao agente patrimonial se existe acumulo de serviço entre o desempenho das atribuições do cargo efetivo com o exercício da função de agente patrimonial, dificultando assim a administração dos bens que estão sob sua responsabilidade. Do total de respondentes, $59,05 \%$ concordam total ou parcialmente com essa afirmativa, com uma média de 3,48. Sendo assim, os agentes patrimoniais acreditam que resulta em excesso de trabalho o acúmulo dessas duas atividades.

Porém, ao correlacionarmos com a pergunta 09 cujo texto versa sobre a vantagem em reduzir carga horária de trabalho para utilizar esse tempo excedente na administração dos bens patrimoniais sob responsabilidade dos agentes patrimoniais, percebe-se que nas respostas obtidas na questão 09, que esses mesmos agentes que afirmam existir excesso de trabalho, não pretendem diminuir a sua carga de trabalho para aplicá-las nas atividades de gestão patrimonial, o que pode fazer presumir uma insatisfação em cumprir as atividades afetas ao controle de bens, como será visto na questão 18 à frente. 


\section{Tabela 15: Dados da questão 15 do questionário de entrevista}

Questão 15: Existe acumulo de serviço entre a função para qual se é remunerado e a de agente patrimonial, dificultando assim na administração dos bens que estão sob sua responsabilidade.

\begin{tabular}{c|l|l|l|l|l|l}
\hline $\begin{array}{c}\text { Nota 1 } \\
\text { Discorda } \\
\text { totalmente }\end{array}$ & $\begin{array}{l}\text { Nota 2 } \\
\text { Discorda } \\
\text { parcialmente }\end{array}$ & $\begin{array}{c}\text { Nota 3 } \\
\text { Não } \\
\text { concorda } \\
\text { e nem } \\
\text { discorda }\end{array}$ & $\begin{array}{l}\text { Nota 4 } \\
\text { Concorda } \\
\text { parcialmente }\end{array}$ & $\begin{array}{l}\text { Nota 5 } \\
\text { Concorda } \\
\text { totalmente }\end{array}$ & Média & $\begin{array}{l}\text { Desvio } \\
\text { Padrão }\end{array}$ \\
\hline $\mathbf{1 2 , 3 8 \%}$ & $\mathbf{1 4 , 2 9 \%}$ & $\mathbf{1 4 , 2 9 \%}$ & $\mathbf{3 1 , 4 3 \%}$ & $\mathbf{2 7 , 6 2 \%}$ & $\mathbf{3 , 4 8}$ & $\mathbf{1 , 3 6}$ \\
\hline
\end{tabular}

Fonte: dados da pesquisa

Na questão 16, elaborou-se uma afirmativa com o seguinte texto: A estabilidade profissional do servidor público influencia negativamente no controle e monitoramento dos bens móveis sob a sua responsabilidade. De acordo com as resposta vista na tabela 16 adiante, constatou-se que a maioria dos pesquisados, ou seja, 55,24\% discordam total ou parcialmente dessa afirmação, cuja média encontrada foi de $2,48 \%$.

Nesse sentido, os agentes patrimoniais acreditam que apesar de existir a estabilidade funcional prevista no regime estatutário dos servidores públicos, ela não influencia negativamente na responsabilidade sobre a carga patrimonial dos agentes. Assim, na visão dos agentes patrimoniais, a falta de responsabilidade com a carga patrimonial não possui relação direta com a estabilidade profissional.

\section{Tabela 16: Dados da questão 16 do questionário de entrevista}

Questão 16: A estabilidade profissional do servidor público influencia negativamente no controle e monitoramento dos bens móveis sob sua responsabilidade.

\begin{tabular}{c|l|l|l|l|l|l}
\hline $\begin{array}{c}\text { Nota 1 } \\
\text { Discorda } \\
\text { totalmente }\end{array}$ & $\begin{array}{l}\text { Nota 2 } \\
\text { Discorda } \\
\text { parcialmente }\end{array}$ & $\begin{array}{c}\text { Nota 3 } \\
\text { Não } \\
\text { concorda } \\
\text { e nem } \\
\text { discorda }\end{array}$ & $\begin{array}{l}\text { Nota 4 } \\
\text { Concorda } \\
\text { parcialmente }\end{array}$ & $\begin{array}{l}\text { Nota 5 } \\
\text { Concorda } \\
\text { totalmente }\end{array}$ & Média & $\begin{array}{l}\text { Desvio } \\
\text { Padrão }\end{array}$ \\
\hline $\mathbf{2 3 , 8 1 \%}$ & $\mathbf{3 1 , 4 3 \%}$ & $\mathbf{2 3 , 8 1 \%}$ & $\mathbf{1 5 , 2 4 \%}$ & $\mathbf{5 , 7 1 \%}$ & $\mathbf{2 , 4 8}$ & $\mathbf{1 , 1 8}$ \\
\hline
\end{tabular}

Fonte: dados da pesquisa 
Diante dos inúmeros casos de divergência patrimonial vistos diariamente no setor de patrimônio, elaborou-se a pergunta 17 que questiona se existe dificuldade em repassar informações atualizadas sobre os bens patrimoniais que estão sob sua responsabilidade ao setor de patrimônio. Assim, conforme a tabela 17, a maioria dos respondentes concorda total ou parcialmente com essa assertiva, perfazendo um total de $60 \%$. Ao revés, somente $22,86 \%$ discordando dela, parcial ou totalmente. Diversos motivos podem levar a essa dificuldade em atualizar as informações sobre as cargas patrimoniais, um dos principais seria a falta de um controle patrimonial informatizado eficiente que desburocratizasse a atualização patrimonial e também a ausência de inventários patrimoniais periódicos nas unidades.

\section{Tabela 17: Dados da questão 17 do questionário de entrevista}

Questão 17: Existe dificuldade em repassar informações atualizadas sobre os bens patrimoniais que estão sob sua responsabilidade ao setor de patrimônio.

\begin{tabular}{c|l|l|l|l|l|l}
\hline $\begin{array}{c}\text { Nota 1 } \\
\text { Discorda } \\
\text { totalmente }\end{array}$ & $\begin{array}{l}\text { Nota 2 } \\
\text { Discorda } \\
\text { parcialmente }\end{array}$ & $\begin{array}{c}\text { Nota 3 } \\
\text { Não } \\
\text { concorda } \\
\text { e nem } \\
\text { discorda }\end{array}$ & $\begin{array}{l}\text { Nota 4 } \\
\text { Concorda } \\
\text { parcialmente }\end{array}$ & $\begin{array}{l}\text { Nota 5 } \\
\text { Concorda } \\
\text { totalmente }\end{array}$ & Média & $\begin{array}{l}\text { Desvio } \\
\text { Padrão }\end{array}$ \\
\hline $\mathbf{4 , 7 6 \%}$ & $\mathbf{1 8 , 1 0 \%}$ & $\mathbf{1 7 , 1 4 \%}$ & $\mathbf{3 5 , 2 4 \%}$ & $\mathbf{2 4 , 7 6 \%}$ & $\mathbf{3 , 5 7}$ & $\mathbf{1 , 1 8}$ \\
\hline
\end{tabular}

Fonte: dados da pesquisa

No que diz respeito à satisfação pessoal do agente patrimonial, foi elaborado a questão 18, que indaga se existe insatisfação pessoal a respeito das obrigações que são necessárias na realização da atividade de agente patrimonial. Assim, conforme o tabela 18 a seguir, $60 \%$ dos agentes patrimoniais concordam total ou parcialmente com a afirmativa. Nesse sentido, constatou-se que, infelizmente, os agentes patrimoniais estão insatisfeitos com as atividades que exercem como agente patrimonial. Portanto, o presente estudo é de extrema importância para tentar se alcançar incentivos que melhorem o grau de satisfação desses agentes 
patrimoniais, haja vista que na maioria das vezes, a função de agente patrimonial é imposta ao servidor.

Tabela 18: Dados da questão 18 do questionário de entrevista

Questão 18: Existe insatisfação pessoal no que diz respeito às obrigações que são necessárias na realização da atividade de agente patrimonial.

\begin{tabular}{c|l|l|l|l|l|l}
\hline $\begin{array}{c}\text { Nota 1 } \\
\text { totalmente }\end{array}$ & $\begin{array}{l}\text { Nota 2 } \\
\text { Discorda } \\
\text { parcialmente }\end{array}$ & $\begin{array}{c}\text { Nota 3 } \\
\text { Não } \\
\text { concorda } \\
\text { e nem } \\
\text { discorda }\end{array}$ & $\begin{array}{l}\text { Nota 4 } \\
\text { Concorda } \\
\text { parcialmente }\end{array}$ & $\begin{array}{l}\text { Nota 5 } \\
\text { Concorda } \\
\text { totalmente }\end{array}$ & Média & $\begin{array}{l}\text { Desvio } \\
\text { Padrão }\end{array}$ \\
\hline $\mathbf{5 , 7 1 \%}$ & $\mathbf{1 1 , 4 3 \%}$ & $\mathbf{2 2 , 8 6 \%}$ & $\mathbf{4 0 , 0 0 \%}$ & $\mathbf{2 0 , 0 0 \%}$ & $\mathbf{3 , 5 7}$ & $\mathbf{1 , 1}$ \\
\hline
\end{tabular}

Fonte: dados da pesquisa

Além das questões fechadas, analisadas acima, o questionário aplicado também possuiu uma questão aberta. Ela versou sobre os benefícios que a FUB poderia propor para estimular a atividade dos agentes patrimoniais, com o seguinte enunciado: Quais benefícios a FUB poderia oferecer aos seus agentes patrimoniais para estimulá-los no desempenho de suas atividades? Tendo-lhes sido disponibilizado um campo para resposta com até 350 caracteres. O objetivo dessa pergunta aberta foi coletar entre os entrevistados diversas sugestões de incentivos que poderiam ser fornecidos pela FUB para estimular os agentes patrimoniais a exercerem melhor a sua função.

Embora tenha havido 14 abstenções, obtivemos um total de 99 sugestões nos 105 questionários respondidos. Isso porque muitos ofereceram mais de uma sugestão nas suas respostas individuais. Essas respostas, em seguida, foram classificadas em 12 tipos de incentivos propostos pelos agentes patrimoniais, quais sejam:

1. Aplicação de punições conforme a legislação;

2. Aumento do número de agentes patrimoniais;

3. Controle patrimonial informatizado mais eficiente;

4. Desnecessidade de incentivos; 
5. Diminuição da carga horária;

6. Instituição de incentivos monetários;

7. Instituição de incentivos não monetários;

8. Maior atualização e divulgação dos bens móveis de forma periódica pela UnB;

9. Melhoria da gestão do setor de patrimônio;

10. Melhoria da segurança na UnB;

11. Prestação de orientações e divulgação das normas patrimoniais pela UnB;

12. Tornar a carga patrimonial facultativa.

\section{Gráfico 6: Respostas da questão aberta do questionário de entrevista}

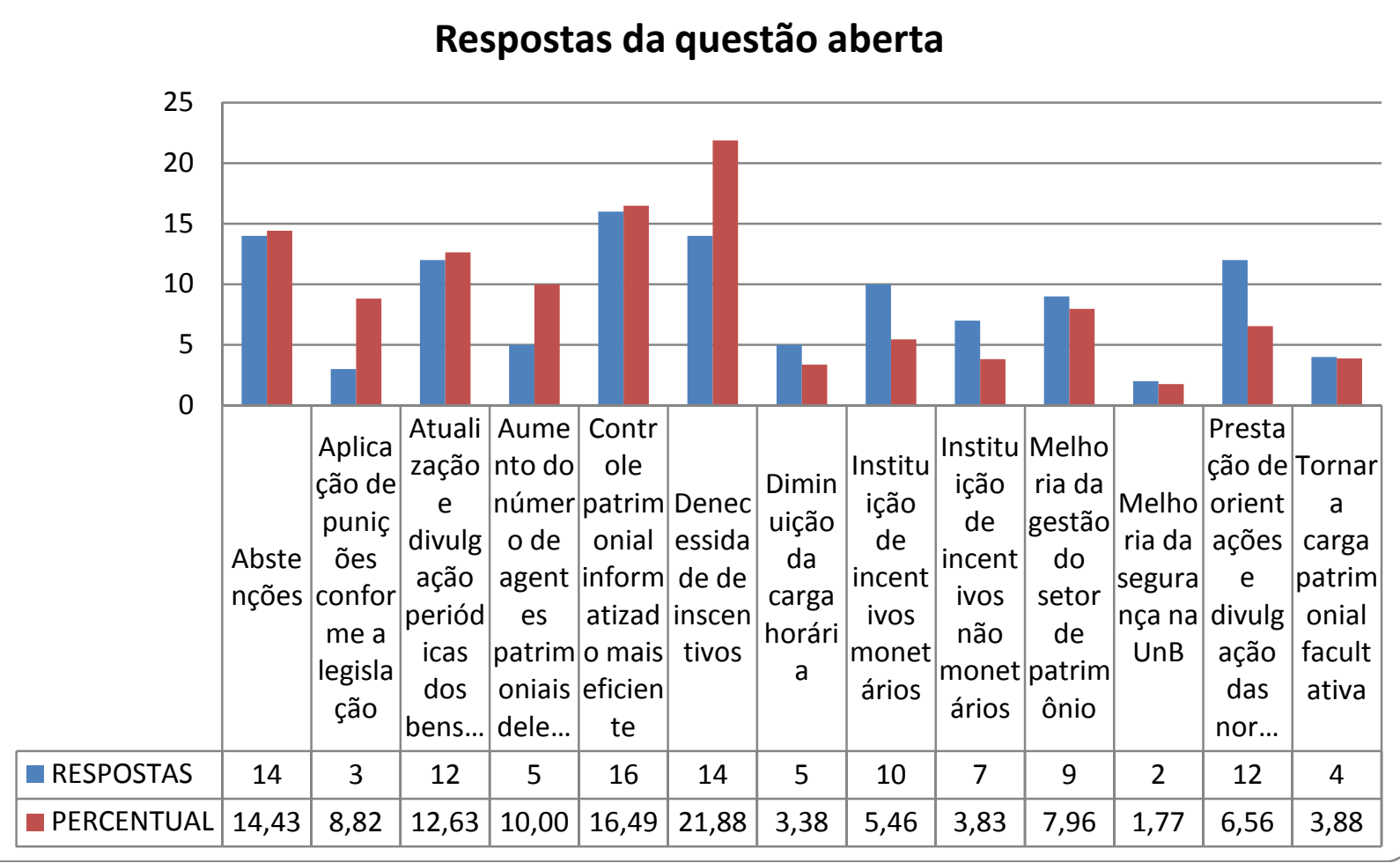

Fonte: dados de pesquisa

Sobre a diminuição da carga horária, 05 agentes patrimoniais acreditam que esse seria um importante incentivo para auxiliar na gestão da carga patrimonial. No caso de docentes poderia diminuir a carga horária de ensino para dedicar-se mais as atividades patrimoniais e no caso de servidor técnico-administrativo, parte da carga horária normal de trabalho deveria ser dedicada para a função de agente patrimonial. Essa carga horária poderia ser distribuída quinzenal, mensal ou semestralmente. 
No quesito "tornar a carga patrimonial facultativa", 04 agentes patrimoniais sentem-se obrigados e os mesmos afirmam que deveriam ser convidados a exercerem a função de agentes patrimoniais. Atualmente, segundo a legislação patrimonial, os servidores investidos em função de chefia, direção e assemelhados têm responsabilidade pelo acervo patrimonial pertencente ao seu Centro de Custo, além de todo servidor que é indicado pela chefia.

Com relação ao incentivo que versa sobre prestação de orientações pela UnB, observou-se que houve 12 respostas nesse sentido. Essas orientações poderiam ser fornecidas de diversas formas, por meio de cursos ou palestras que divulgassem a importância e responsabilidade dos agentes patrimoniais e as normas de gestão patrimonial da universidade, bem como por meio de um manual ou cartilha distribuída entre os agentes patrimoniais com as principais informações de como cuidar com zelo do patrimônio. Foi sugerido, inclusive, que o setor pessoal responsável pela posse do servidor na universidade, entregasse um manual com normas e legislações referentes às responsabilidades do servidor, em formato de livreto. Além disso, muitos agentes patrimoniais concordam que o setor de patrimônio deveria orientar sobre o acesso às informações de funcionamento do sistema de patrimonial (SIPAT) e de como gerenciar/acompanhar os bens móveis.

A instituição de incentivos não monetários foi outra sugestão também eleita pelos agentes patrimoniais, sendo citada em 07 respostas. Como exemplo, sugeriram-se prêmios de reconhecimento para valorizar o servidor e elogios individuais. Os incentivos monetários também foram relatados pelos agentes patrimoniais, estando presente em 10 respostas. Esses incentivos monetários poderiam ser fornecidos, segundo os agentes patrimoniais, de forma direta por meio de gratificações e de forma indireta, através de pontos na progressão 
funcional. Vale ressaltar, que os agentes patrimoniais que recebe a função gratificada para exercer as funções de chefia, direção e assemelhados inclui a atividade de agente patrimonial nessas funções remuneradas. Alguns agentes também sugerem algum tipo de seguro patrimonial, outros, que o pagamento de adicional estivesse relacionado com o valor dos bens sob responsabilidade dos agentes patrimoniais.

Um incentivo presente em um grande número de respostas (16) foi o controle patrimonial informatizado mais eficiente. Os agentes patrimoniais sugerem que a universidade implemente um controle automático acessível via Internet ou Intranet, que permita um pronto atendimento das demandas das unidades no que se refere à criação, baixas patrimoniais, transferência de bens, por meio de senhas pessoais ou até mesmo por biometria. Esse sistema informatizado visa desburocratizar diversos processos, como o processo de designação, controle e acompanhamento dos bens. Alguns agentes patrimoniais sugerem contratar terceirizados para viabilizar a administração desse novo sistema informatizado. Na prática, as solicitações de registro, baixas, transferências são feitas através de documentos que devem estar assinados para que sejam cumpridos pelo setor de patrimônio, burocratizando os processos, visto que os mesmos muitas vezes acabam se perdendo no caminho entre as unidades solicitantes e o setor de patrimônio, responsável pela execução.

Outro incentivo sugerido pelos entrevistados, num total de 12 sugestões, foi que a UnB realizasse periodicamente uma maior atualização e divulgação dos bens móveis. Alguns agentes patrimoniais acreditam, primeiramente, que a FUB deveria fazer levantamento periódico individual da carga patrimonial, identificando "in loco" o lugar no qual o bem se encontra e sob a responsabilidade de quem esta o bem. Em seguida, o envio periódico de emails com status atualizado da carga patrimonial do servidor, alterações na carga e outras 
informações sobre baixa patrimonial e aquisição de novos bens. Outros agentes patrimoniais sugerem a construção de uma página na internet da UnB com fácil acesso a esses dados. Para alguns docentes, os servidores do setor de patrimônio deveriam ficar responsáveis por periodicamente checar se a carga patrimonial do docente está de acordo, na prática, essa sugestão é inviável devido ao baixo número de funcionários do setor de patrimônio e ao gigantesco universo de bens que estão espalhados nos 4 campi da Universidade.

No que diz respeito ao incentivo melhora da gestão do setor de patrimônio, observouse que 09 agentes patrimoniais consideram esse tipo de incentivo importante. Uma das sugestões foi que a UnB disponibilizasse funcionário responsável para o controle dos bens, agilidade nos pedidos de baixa patrimonial, disponibilização de lista de bens patrimoniais para cada agente patrimonial de uma maneira rápida e fácil sem passar pela secretaria de cada centro de custo.

Outro aspecto discutido na pergunta aberta foi à questão da segurança institucional. Assim, 02 respostas tratavam da falta de segurança na UnB como fator desestimulante. Portanto, maior segurança no campus significa maior controle das pessoas que entram e saem da UnB, e consequentemente menor probabilidade de desaparecimento de bens móveis. Também em 02 respostas, observou-se que dois agentes patrimoniais consideravam as punições atualmente presentes na legislação como suficiente para incentivar os agentes patrimoniais a terem mais responsabilidade sobra às cargas patrimoniais. Levantou-se também a questão de que as punições só poderiam ser aplicadas a partir de um processo confiável de gestão patrimonial, pois o próprio sistema não é eficiente o suficiente para poder aplicar punições. Outro aspecto abordado pelos agentes patrimoniais visava um maior rigor na aplicação das punições atualmente presente na legislação. 
Com relação ao número de agentes patrimoniais, 05 respostas versavam sobre o aumento do número de agentes patrimoniais cadastrados, de forma a distribuir equitativamente entre mais servidores as cargas patrimoniais. Sendo assim, a responsabilidade pelos bens deveria ser compartilhada entre todos os servidores que atuam nos ambientes institucionais e não somente ao chefe ou a alguns servidores.

Um total de 14 entrevistados se abstiveram de responder a questão aberta. Isso pode significar que o assunto abordado na pergunta aberta, qual seja, os benefícios que a FUB poderia propor para estimular a atividade dos agentes patrimoniais, é irrefletido por parte dos agentes patrimoniais, tendo em vista que ainda não existe no Brasil uma cultura organizacional disseminada de instituição de incentivos no âmbito das instituições públicas. Isso se reflete também na parca produção científica sobre o tema no Brasil, um dos grandes desafios inclusive enfrentado nessa pesquisa, que foi a dificuldade de encontrar referencial teórico do tema em questão.

Finalmente, 14 agentes patrimoniais responderam que não havia a necessidade de instituição de incentivos. Após detida análise dos dados coletados por meio da aplicação de questionários aos agentes patrimoniais da UnB, foi possível perceber que a maioria dos agentes patrimoniais considera mudanças institucionais mais eficazes para a solução dos problemas existentes com a gestão patrimonial do que a instituição de incentivos, financeiros ou não.

Fazendo um resumo das respostas abertas, pode-se perceber que os agentes patrimoniais atribuíram maior peso pela responsabilidade dos problemas relacionados à gestão patrimonial à Instituição UnB e não a sua própria conduta funcional. Nesse sentido, foi 
construído um gráfico para melhor visualização, onde se considerou 3 tipos de preferência dos entrevistados nas respostas abertas: I) mudanças institucionais para as respostas que foram classificadas como aplicação de punições conforme a legislação, aumento do número de agentes patrimoniais, controle patrimonial informatizado mais eficiente, maior atualização e divulgação dos bens móveis de forma periódica pela UnB, melhoria da gestão do setor de patrimônio, melhoria da segurança na UnB, prestação de orientações/divulgação das normas patrimoniais pela UnB e tornar a carga patrimonial facultativa; II) instituição de incentivos, as respostas que foram classificadas como diminuição da carga horária; instituição de incentivos monetários e não monetários e III) desnecessidade de incentivos.

\section{Gráfico 7: Resumo das respostas da questão aberta do questionário de entrevista}

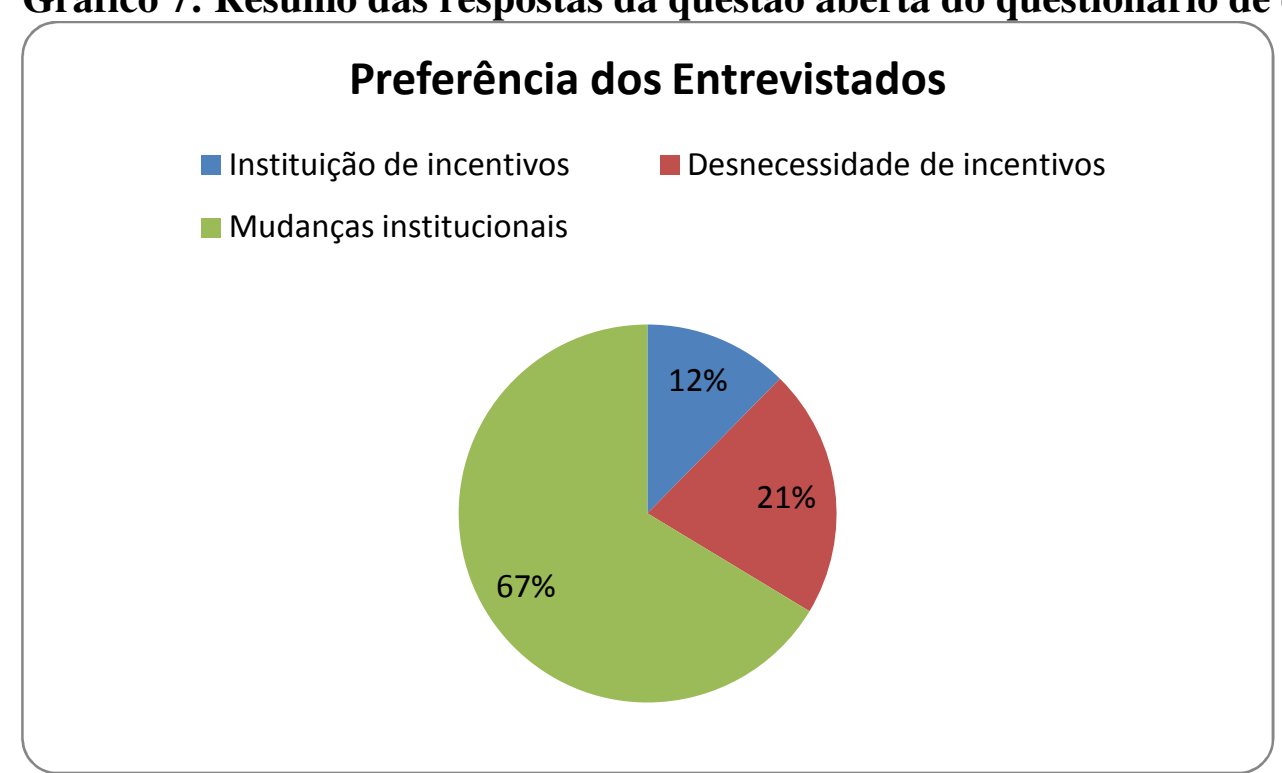

Fonte: dados de pesquisa 


\section{CONSIDERAÇÕES FINAIS}

A gestão patrimonial tem sido vista como sem importância nas organizações públicas, por essa razão existe uma a tendência para que os bens móveis dessas instituições tendam a ter um controle pouco eficaz e que os agentes patrimoniais acabam negligenciando o processo de gestão e controle patrimonial. Assim, é necessário prover os setores de patrimônio de recursos materiais, humanos e financeiros como forma de minimizar essa perda patrimonial.

É importante ressaltar que as fontes literárias são escassas quanto à gestão patrimonial no âmbito das instituições públicas. Nesse contexto, as informações analisadas no presente trabalho podem ser um grande contributo para a melhoria da gestão patrimonial dos setores de patrimônio das instituições públicas federais de ensino.

A partir do constructo teórico da Teoria da Agência, a presente pesquisa lançou luzes sobre os benefícios da instituição de uma política de incentivos no âmbito da relação entre a UnB e os seus servidores, que possuem carga patrimonial sob sua responsabilidade, denominados de agentes patrimoniais. A análise dos dados da pesquisa empírica indicou que a Teoria da Agência apresenta fundamentos necessários e básicos para a realização deste trabalho, quando combinada com a teoria dos incentivos. Assim, a experiência da UnB, apresentada ao longo do presente trabalho, pode servir de paradigma para as demais instituições públicas federais de ensino do país. Ressalta-se ainda, que as modificações na administração patrimonial que foram propostas no presente trabalho foram feitas com base no modelo de gestão patrimonial atual, assim, não foi um objetivo desse estudo propor um novo modelo de gestão patrimonial. 
Diversos comportamentos indesejáveis por parte dos agentes acabam gerando conflitos de agência entre a universidade e os seus agentes patrimoniais. Dentre os principais observou-se assimetria de informações entre os bens que estão in loco e o que está registrado no SIPAT levando a dificuldades de controle e monitoramento pela UnB. Outro aspecto relevante que pode ser observado foi o descumprimento da legislação por parte dos agentes patrimoniais no que tange a responsabilidade sobre os bens móveis da universidade. É importante ressaltar que as leis, normas e regulamentos que disciplinam a gestão patrimonial têm o intuito de nortear os procedimentos patrimoniais nas instituições públicas. Sendo assim, a responsabilidade desses atores com a carga patrimonial que está sob sua guarda e zelo é imprescindível para o alcance dos objetivos propostos pelo setor de patrimônio. Cada agente patrimonial tem um papel primordial nas inúmeras tarefas presentes na gestão patrimonial, desde o recebimento do bem até o desfazimento do mesmo. Infelizmente, na prática observase o descrédito na eficácia dos instrumentos de controle, tanto por parte dos dirigentes quanto por parte dos servidores e o baixo controle da confiabilidade das informações no controle interno e externo deixando o setor de patrimônio em segundo plano, apesar da enorme quantidade de recursos financeiros aplicados na compra e descarte do mobiliário empregado pela Universidade no cumprimento de suas finalidades.

No que tange as principais irregularidades relatadas pelos centros de custo da UnB, pode-se identificar que as mais significativas diziam respeito aos bens não localizados pelos agentes patrimoniais e a dificuldade em transferir as cargas patrimoniais entre os agentes patrimoniais A falta de responsabilidade entre os agentes patrimoniais no que tange a posse e guarda dos bens móveis que estão sob seu uso acaba gerando dificuldades no controle patrimonial pela UnB, além de acarretar transtornos legais aos agentes patrimoniais. 
A cooperação dos agentes patrimoniais com as políticas institucionais é indispensável para evitar divergências nas alocações dos bens móveis. Inconsistências de dados prejudicam a alocação de recursos, o controle interno e a prestação de contas aos órgãos de controle externo. É inegável que mudanças na legislação, principalmente no que diz respeito ao controle final dos bens móveis, podem contribuir para uma melhor gestão patrimonial. Todavia, a instância regulatória por si só não é suficiente para evitar seu descumprimento e aumentar a cooperação.

Pode-se perceber ao longo deste trabalho, diversas iniciativas de âmbito institucional que podem ser utilizadas para resolver os conflitos de agência entre o servidor público detentor de carga patrimonial e a universidade, alinhando os interesses entre os mesmos, nesse sentido, pode-se destacar dentre elas, a criação de um manual aos agentes patrimoniais desenvolvido pela Diretoria de Gestão de Materiais em conjunto com a coordenação de patrimônio, com as informações necessárias sobre o funcionamento e atribuições necessárias do setor de patrimônio, consolidando os procedimentos a serem executados em cada um dos processos de gestão patrimonial. Outro meio para se alcançar a eficácia da gestão patrimonial seria através de cursos e palestras proferidos aos agentes patrimoniais pela Diretoria de Gestão de Materiais em conjunto com a coordenação de patrimônio, essa troca de informações e experiências entre os servidores do patrimônio e os agentes patrimoniais é de extrema importância para compreendermos as necessidades e demandas presentes em ambos os lados.

Outra iniciativa que poderia ser adotada pela FUB para melhorar a gestão patrimonial e consequentemente minimizar os conflitos de agência, seria um controle informatizado mais eficaz, seja via internet ou via intranet. O uso desses tipos de ferramentas poderia 
proporcionar um rápido acesso às informações patrimoniais de forma simples, intuitiva, automatizada, integrada e proativa.

Implantar órgãos setoriais de administração patrimonial nos centros de custos que possuam uma grande de quantidade de bens móveis, descentralizando algumas atividades que são exclusivas do setor de patrimônio, como: controle, movimentações e transferência de bens e de responsabilidades, também seria outra iniciativa por parte da universidade. Ressalta-se ainda que os órgãos setoriais (centros de custos) seriam coordenados em torno do órgão central (Diretoria de Gestão de Materiais). A administração superior deveria apoiar o setor de patrimônio através do planejamento estratégico institucional, inclusive contratando mais servidores técnico-administrativos para atuarem no setor de patrimônio.

O estudo apontou também para a existência de perfis distintos de agentes patrimoniais na $\mathrm{UnB}$, de modo a indicar que determinados incentivos seriam mais eficientes para minorar os problemas na gestão patrimonial, como por exemplo, observou-se, principalmente: aplicação de punições conforme a legislação, aumento do número de agentes patrimoniais, controle patrimonial informatizado mais eficiente, maior atualização e divulgação dos bens móveis de forma periódica pela UnB, melhoria da gestão do setor de patrimônio, melhoria da segurança na UnB, prestação de orientações/divulgação das normas patrimoniais pela UnB; tornar a carga patrimonial facultativa; diminuição da carga horária; instituição de incentivos monetários e não monetários.

Portanto, após a análise dos dados coletados com a aplicação de questionário, a pesquisa documental e a bibliográfica, o presente estudo constatou que a administração de patrimônio 
necessita de mudanças que levem a desenvolver um processo de gestão eficiente e confiável refletindo diretamente no comportamento dos agentes patrimoniais no que tange a responsabilidade dos bens móveis da Universidade de Brasília.

\section{6 - REFERÊNCIAS}

AGHION, P.; TIROLE, J. Formal and Real Authority in Organizations. Journal of Political Economy, University of Chicago Press, vol. 105(1), 1997, p. 1-29.

AKERLOF, George A. The market for" lemons": Quality uncertainty and the market mechanism. The quarterly journal of economics, 1970, p. 488-500.

ALCHIAN, A.; DEMSETZ, H. Production, information costs and economic organization.American EconomicReview, v.62, dez.1972, p.777-795.

ALYRIO, R. D. Métodos e técnicas de pesquisa em administração. vol.único. Rio de Janeiro: Fundação CECIERJ, 2009, 281p.

ARAÚJO, M.; SANCHEZ, O. A. A corrupção e os controles internos do estado. Lua Nova, v. 65, 2005, p. 137-73.

ARROW, K. J. The Economics of Agency, in Pratt e Zeckhauser. Principals and Agents: The Structure of Business. Harvard Business School Press, 1985, p. 37-51.

ARRUDA, G. S.; MADRUGA, S. R; FREITAS Jr., N. I. de. A governança corporativa e a teoria da agência em consonância com a controladoria. Revista de Administração da Universidade Federal de Santa Maria (UFSM), Santa Maria, v. I, n. 1, jan./abr. 2008, p. 7184.

AZEREDO, T. M. A. A relação de agência na ótica da nova economia institucional. Revista Senac, v. 3, 2007, p. 2.

AZEVEDO, P. F. Integração Vertical e Barganha. São Paulo: USP. 1996. 221 f. Tese (Doutorado em Economia) - Programa de Pós-Graduação em Economia, Departamento de Economia, Universidade de São Paulo, São Paulo, 1996.

BARBETTA , P. A. Estatística aplicada às ciências sociais. 5. ed. Florianópolis: Editora da UFSC, 2003.

BARNARD, C. The functions of the Executive. 39. ed. Cambridge, MA: Harvard University Press, 1938, 334 p. 
BENEDICTO, S. C. de; RODRIGUES, Â. C.; ABBUD, E. L. Governança Corporativa: Uma análise da sua aplicabilidade no setor público. XXVIII ENCONTRO NACIONAL DE ENGENHARIA DE PRODUÇÃO A integração de cadeias produtivas com a abordagem da manufatura sustentável. Rio de Janeiro, RJ, Brasil, 13 a 16 de outubro de 2008, p.9. Disponível em:<http://www.abepro.org.br/biblioteca/enegep 2008_TN_STO_079_548_ 11648. pdf $>$. Acessado em: 06 set. 2015.

BERNARDES, J. F. Gestão Patrimonial: materiais permanentes e bens móveis. Florianópolis: Imprensa Universitária/Universidade Federal de Santa Catarina (UFSC), 2008, 174p.

Administração patrimonial nas instituições públicas federais no contexto da gestão do conhecimento. Florianópolis: UFSC. 2008. 267 f. Tese (Doutorado) - Programa de PósGraduação em Engenharia e Gestão do Conhecimento, Universidade Federal de Santa Catarina, Florianópolis, 2009.

BHIDE, A. Deficient Governance. Harvard Business Review. EUA: nov-dez 1994. p. 129 139.

BRANCO, A.S.C. Conflito de interesse na administração pública: estudo de caso na Prefeitura Municipal de Cachoerinha-RS. São Leopoldo-RS:Universidade do Vale do Rio dos Sinos. 2011. 124 f. Dissertação (Mestrado em Ciências Contábeis). Programa de PósGraduação em Ciências Contábeis. 2011.

BRASIL. Decreto $n^{\circ} 99.658$ de 30 de outubro de 1990. Regula o reaproveitamento, a movimentação, a alienação e outras formas de desfazimento de material no âmbito da Administração Pública Federal. Disponível em: $<$ http://www.planalto.gov.br/ccivil_03/decreto/antigos/D99658.htm>. Acessado em: 02 jul. 2015.

- Instrução Normativa da Secretaria de Administração Pública da Presidência da República $\mathrm{n}^{\mathrm{o}}$ 205, de 08 de abril de 1988. Disponível em: < http://www.daf.unb.br/images/DGM/inst_norma_205_88.pdf>. Acessado em: 28 out.2014.

Lei $\mathrm{n}^{\circ}$ 4.320, de 17 de março de 1964. Estatui Normas Gerais de Direito Financeiro para elaboração e controle dos orçamentos e balanços da União, dos Estados, dos Municípios e do Distrito Federal. Disponível em: < http://www.planalto.gov.br/ccivil_03/leis/14320.htm >. Acessado em: 28 out. 2014.

BRENNAM, M. Incentives, Rationality and Society. Corporate Governance at the Crossroads; a Book of Reading.Mc Graw-Hill. New York. 2005.

BRISOLA, J. Teoria do agenciamento na contabilidade - a contabilidade e o processo de comunicação. ConTexto, Porto Alegre, v.4, n.7, 2ºm. 2004.

BUGARIN, B. J. Controle das finanças públicas - Uma visão geral. Revista do Tribunal de Contas da União, n. 59, 1994, p.12.

CABRAL, S. "Além das grades": uma análise comparada das modalidades de gestão do sistema prisional. Salvador: UFBA. 2006. 293 f. Tese (Doutorado em Administração) - 
Programa de Pós-graduação da Escola de Administração, Universidade Federal da Bahia, Salvador, 2006.

CARVALHO de, A. G. Governança Corporativa no Brasil em perspectiva. Revista de Administração da Universidade de São Paulo, v.37, n.3, julho/setembro 2002, p.19-32.

CHERMAN, B. Auditoria: externa, interna e governamental. Rio de Janeiro: F. Bastos, 2005.

COASE, R. The Nature of the Firm.Economica, New Series, v. 4, n. 16, nov. 1937, p. 386405.

The problem of social cost.Journal of Law and Economics, v.3, 1960, p. 1-44.

CONTROLADORIA GERAL DA UNIÃO (CGU). Coletânea de Entendimentos - Perguntas e respostas. Edição Revisada. Brasília, maio de 2013. Disponível em: $<$ http://www.cgu.gov.br/Publicacoes/auditoria-e-fiscalizacao/arquivos/ife.pdf $>$. Acessado em : 17 set. 2015.

COSTA NETO, P. L. O. Estatística. 1. ed. 18 a reimpressão. São Paulo: Editora Edgard Blücher Ltda, 2000.

CUNHA Jr., Dirley da. Curso de Direito Administrativo. 8. ed. Salvador: JusPODIVM, 2009.

DIAS, A. F. da S. Gestão Patrimonial na Administração Pública Estadual. Santa Catarina, SC, $2006 . \quad$ Disponível em: $<$ http://www3.sef.sc.gov.br/controle_interno2/orientacoes_contabeis/seminariodcog/ManualP at.pdf> Acesso em: 20/06/2015.

EISENHARDT, K. Agency Theory: Na Assessment and Review. Academy of Management Review, vol.4, n.1, 1989, p.57-74.

FARINA, E. M. M. Q.; AZEVEDO, P. F.; SAES, M. S. M. Competitividade: mercado, estado e organizações. São Paulo: Singular, 1997.

FUNDAÇÃO UNIVERSIDADE DE BRASÍLIA. Normas e Registro e Controle de Bens Patrimoniais Móveis da FUB. Anexo à Resolução n. 17/2004, do Conselho Diretor da FUB. Brasília, $\quad$ set. 2004. Disponível em: http://www.daf.unb.br/images/DGM/normas_rcbpm_fub.pdf>. Acessado em: 28 out. 2014.

.Ato da Reitoria $\mathrm{n}^{\mathrm{o}} 1.083 / 2013$. Disponível em: $<$ http://www.daf.unb.br/images/DGM/atas/Ato_GRE_1083-13.pdf $>$. Acesso em 10 de julho de 2015.

Resolução do Decanato de Administração no 0023/2013. Disponível em: < http://www.daf.unb.br/images/DGM/Circ-03-Res-DAF-23-13.pdf>. Acesso em 01 de junho de 2015 .

FURUBOTN, E; RICHTER, R. The New Institutional Economics: An Assessment. The New Institutional Economics. College Station, Texas: Texas A\&M Press. 1991. 
GOMES, O. Contratos. 26. ${ }^{\mathrm{a}}$ ed. Rio de Janeiro: Forense, 2007.

GOMES, F. A; DINIZ, T. C. Impactos de seleção adversa e risco moral sobre a contratação e o desempenho dos servidores públicos: uma análise do estado de minas gerais. Encontro da Associação Nacional dos Programas de Pós Graduação em Administração (ENANPAD), 2006, Salvador.

GONÇALVES, R. S de; TAVARES, A. L de. Seleção Adversa: um campo para pesquisas em contabilidade. RUC - Revista Unieuro de Contabilidade, v.1, n.1, set.2008.

GONG, Y. Subsidiary staffing in multinational enterprises: agency, resources, and performance.Academyof Management Journal, v. 46, Dec.2003, p. 728-739.

GÜNTHER, H. Pesquisa Qualitativa versus Pesquisa Quantitativa: Esta é a Questão? Revista Psicologia: Teoria e Pesquisa, vol.22, n.2, mai./ago. 2006, p.201-210.

HAYES, B. E. Medindo a satisfação do cliente: desenvolvimento e uso de questionários. Rio de Janeiro: Qualitymark, 2001.

IBGC. Instituto Brasileiro de Governança Corporativa. Código das melhores práticas de governança corporativa.4.ed. / Instituto Brasileiro de Governança Corporativa. São Paulo, SP : IBGC, 2009.73 p. Disponível em: <http:// www.ibgc.org.br>. Acesso em: 05 set. 2015.

IFAM. Manual de Administração Patrimonial de Bens Móveis do Ativo Permanente do Instituo Federal de Educação, Ciência e Tecnologia da Amazônia (IFAM). 2012. Disponível.em:<http://www2.ifam.edu.br/arquivos>. Acessado em 05 de julho de 2015.

INTERNATIONAL FEDERATION OF ACCOUNTS - IFAC. Study 13: Governance in the public sector. New York: 2001. Disponível em: <http://www.ifac.org/publicationsresources/study-13-governance-public-sector>. Acessado em: 09 de setembro de 2015.

JENSEN, M. C.; MECKLING, W. H. Theory of the firm: Managerial behavior, agency costs and ownership structure. Journal of Financial Economics, v. 3, n. 4, 1976, p. 305-360.

KRONBERG, H. Gestão de patrimônio pessoal: à luz do ordenamento jurídico. Curitiba: Hemus, 2002.

LAFFONT, J.J.; MANTIMORT, D. The Theory of Incentives: the principal-agent model. Oxford: Pricenton University Press, 2002, 422 p.

LEDESMA, R. AlphaCI: un programa de cálculo de intervalos de confianza para el coeficiente alpha de Cronbach. Psico - USF, v.9, n.1, jan./jun. 2004, p.31-37.

LEVIN, J. Estatística Aplicada a Ciências Humanas. 2a. Ed. São Paulo: Editora Harbra Ltda, 1987.

LEVINE, D. M.; BERENSON, M. L.; STEPHAN, D. Estatística: teoria e aplicações; usando Microsoft Excel em português. Trad. Teresa Cristina Padilha de Souza. Rev. Sérgio da Costa Cortes. Rio de Janeiro: LTC - Livros Técnicos e Científicos, 2000. 811p. 
MACAGNAN, C. B. Disclosure de información voluntaria causas y consecuencia de revelar recursos intangibles. Ed. Entre meios, 2008.

MARSCHKE, G. Incentives in government: evidence from US Job Training Programme for the economically disadvantaged. Market and Public Organizations, Bristol, n.3, jun. 2000.

MARTINS, P. G.; ALT, P. R. C. Administração de materiais e recursos patrimoniais. $2^{\mathrm{a}}$. ed. São Paulo: Saraiva, 2006.

MATO, C. A., VEIGA, R. T. Avaliação da qualidade percebida de serviços: um estudo em uma organização não-governamental. Caderno de Pesquisa em Administração, v. 07, n. 3, São Paulo, Jul/Set de 2000, p. 27-42.

MEIRELLES, H. L. Direito Administrativo. 30. ed. São Paulo: Malheiros Editora, 2005.

MELLO, G.R. de. Governança Corporativa no Setor Público Federal Brasileiro. São Paulo: USP. 2006. 119 f. Dissertação (Mestrado). Faculdade de Economia, Administração e Contabilidade da Universidade de São Paulo, São Paulo, 2006.

MERCHANT, K. A.; VAN der STEDE, W.A. Manegement Control Systems: Performance Measurement, Evaluation and Incentives. Pearson, 2007.

MIGUEL, P. A. C., SALOMI, G. E. Uma revisão dos modelos de medição de qualidade em serviços. Revista Produção, v. 14. n. 1, Rio de Janeiro, 2004, p. 12-30.

MONTANA, P. J.; CHARNOV, B. H. Administração. São Paulo: Saraiva, 2001. 544 p.

NORTH, D. Structure and Change in Economic History. New York: W.W. Norton \& Co, 1981.

Institutions. Institutional Change and Economic Performance.Cambridge University Press, 1990, 152 p.

OLIVEIRA, M. C.; RIBEIRO, M. S.; SAMPAIO, M. S. A.; CARVALHO, F. A. Os Efeitos da Adoção dos Conceitos e das Práticas de Governança Corporativa na Transparência das Informações Evidenciadas por Empresas Brasileiras do Setor de Papel e Celulose. In: $4^{\circ}$ Congresso USP de Controladoria e Contabilidade, 2004, São Paulo. Anais do $4^{\circ}$ Congresso USP de Controladoria e Contabilidade. São Paulo: FEA/USP, 2004.

PAULA, A. P. P. de. Entre a administração e a política: os desafios da gestão pública democrática. Campinas: UNICAMP. 2003. 281 f. Tese (Doutorado em Ciências Sociais). Departamento de Ciência Política do Instituto de Filosofia e Ciências Humanas da Universidade Estadual de Campinas, Campinas - SP. 2003.

PESTANA, M. H e CAGEIRO, J. N. Análise de Dados para Ciências Sociais - A Complementaridade do SPSS. 4. ed. Lisboa: Edições Silabo, 2005.524 p. 
PINTO Jr., H. Q.; PIRES, M. C. P.Assimetria de Informações e Problemas Regulatórios. Fev. 2000. Disponível.em: <http://ppge.ufrgs.br/giacomo/arquivos/eco02036/pintojr-pires2000.pdf>. Acessado em: 11 setembro de 2015.

POSNER, E. A. Agency Models in Law and Economics. John M. Olin Law \& Economics Working Paper. n. 92, série 2. 2000.

PRZEWORSKI, A. 1998. Sobre o desenho do Estado: uma perspectiva agente x principal. In Bresser Pereira LC, Spink P (orgs.). Reforma do Estado e administração pública gerencial. Editora da FGV, Rio de Janeiro, 314 pp.

ROBBINS, S.P. Fundamentos ao Comportamento Organizacional. São Paulo: Pearson Prentice Hall, 2009.

ROBERTS, J. Designing incentives in organizations. Journal of Institutional Economics, 6(1), 2010, p. 125-132.

ROSS, S. A. The economic theory of agency: The principal's problem. The American Economic Review, p. 134-139, 1973.

SANTOS, G. dos. Gestão Patrimonial. 4. ed. rev., atual. e ampl. Florianopolis: Secco, 2012.

SAPPINGTON, D. Incentives in Principal-Agent Relationships. Journal of Economic Perspectives, v.5, n.2, 1991, p.45-66.

SCHERMERHORN Jr., J. R.; HUNT, J. G.; OSBORN, R. N. Fundamentos de comportamento organizacional. 2. ed. Porto Alegre: Bookman, 2009, 330p.

SELLTIZ, C. et al. Métodos de pesquisa nas relações sociais. São Paulo: Herder/ Editora da Universidade de São Paulo, 1972.

SHIRLEY, M.; MÉNARD, C. Cities awash: a synthesis of the country cases. In: SHIRLEY, M. (ed.). Thirsting of Efficiency: The Economics and Politics of Urban Water System Reform. Oxford: Elsevier Science, 2002, p. 1-42.

SIMON, H. A. Administrative Behaviour,a study of decision making processes in administrative Organization. New York: Macmillan, 3 ed., 1976, 356 p.

SMITH, A. The wealth of nations New York: The modern library (2000), 1776, 1155 p.

STEVENSON, W. J. Estatística Aplicada à Administração. 1. ed. São Paulo: Harbra, 2001.

TRIOLA, M. F. Introdução à Estatística. 7. ed. Rio de Janeiro: LTC, 1999.

UFMG. Manual de Patrimônio da Universidade Federal de Minas Gerais (UFMG).2008.Disponível.em:<https://www.ufmg.br/dlo/arquivo/Dimat/Manual\%20de\%20pa trimonio.pdf $>$. Acessado em 20 de agosto de 2015.

VERGARA, S. C. Métodos de Coleta de Dados no Campo. São Paulo: Atlas. 2009. 
VIEIRA, S. Como elaborar questionários. São Paulo: Atlas. 2009.

VIERA, S. P.; MENDES, A. G. S. T. Governança Corporativa: uma análise de sua evolução e impactos no mercado de capitais brasileiro. Revista Organizações em Contexto (ROC), ano 2, n.3, junho 2006, p. 48-67.

WILLIAMSON, O. Markets and Hierarchies: Analysis and Antitrust Implications, New York, NY: Free Press, 1975.

The Economic Institutions of Capitalism: Firms, Markets, Relational Contracting. New York, The Free Press, 1985, 450 p.

Comparative Economic Organization: The Analysis of Discret Structure Alternatives. Administrative Science Quartely, v.36, 1991, p.269-296.

. The Mechanisms of Governance. Oxford: Oxford University Press, 1996, 429 p.

Public and Private Bureaucracies: A Transaction Cost Economics Perspective. Journal of Law, Economics and Organizations, 15:1, Mar 1999, p-306-342.

XEXÉO, J. A. M. Sistemas de Informação como Instrumento de Programa de Qualidade. Rio de Janeiro, 2001. Tese (Doutorado em Engenharia de Sistemas e Computação) - Universidade Federal do Rio de Janeiro.

ZANELLA, L. C. H. Metodologia de Estudo e de Pesquisa em Administração. Florianópolis : Departamento de Ciências da Administração / UFSC; [Brasília] : CAPES :UAB, 2009 


\section{7 - APÊNDICES}

\subsection{Apêndice A - Questionário}

\section{O OBJETIVO DESSA PESQUISA É ACADÊMICO E NÃO SERÃO DIVULGADAS}

\section{RESPOSTAS INDIVIDUAIS}

Gênero: ( ) Masculino ( ) Feminino

Idade:

Tempo de serviço na UnB (anos): Lotação(local):

Tempo na função de agente patrimonial (anos):

De 0 a 10, sendo 0 a pior nota e 10 a melhor nota, qual nota você daria para si mesmo que pudesse representar a sua dedicação sobre a carga patrimonial que está sob sua responsabilidade:

Indique o grau de concordância em relação à situação dos agentes patrimoniais e os bens móveis da FUB. Preencha a tabela abaixo conforme as notas da seguinte escala:

- Nota 1 se você DISCORDA TOTALMENTE da afirmação apresentada

- Nota 2 se você DISCORDA PARCIALMENTE da afirmação apresentada

- Nota 3 se você NÃO CONCORDA e NEM DISCORDA da afirmação apresentada

- Nota 4 se você CONCORDA PARCIALMENTE com a afirmação apresentada

- Nota 5 se você CONCORDA TOTALMENTE com a afirmação apresentada

Fique a vontade para rasurar e/ou modificar respostas após a leitura de todas as questões

\begin{tabular}{|l|l|l|l|l|l|}
\hline & \multicolumn{4}{|c|}{ Nota } \\
\hline 1) A FUB deveria elaborar e distribuir entre os agentes patrimoniais um & & & & & \\
\hline
\end{tabular}


manual que fornecesse informações básicas relativas à gestão patrimonial dos seus bens móveis.

2) A FUB deveria ministrar cursos/palestras aos agentes patrimoniais no intuito de divulgar a importância e responsabilidade da atividade patrimonial dos agentes.

3) As normas e regulamentos que versam sobre responsabilidade e gestão patrimonial são amplamente divulgadas pela FUB.

4) A FUB deveria analisar critérios específicos que identificasse qual seria o melhor perfil profissional para a escolha do agente patrimonial.

5) Em geral, os servidores (técnicos e docentes) possuem perfis adequados para serem agentes patrimoniais.

6) A gestão patrimonial da FUB deveria desenvolver um processo de gestão eficiente e confiável para que os agentes patrimoniais pudessem sentir-se tranquilo quanto a sua responsabilidade no controle e monitoramento de seus bens móveis.

7) A gestão patrimonial da FUB é eficiente para solucionar os problemas oriundos da falta de controle e monitoramento dos bens móveis sob responsabilidade dos agentes patrimoniais.

8) Têm sido eficazes as punições aos agentes patrimoniais exercidas atualmente pela FUB para os bens móveis não localizados, tais como: ressarcimento ao erário; não obtenção de certidão negativa de débitos patrimoniais nos processos de aposentadoria, redistribuição e exoneração.

9) Haveria vantagem em reduzir carga horária de trabalho para utilizar esse tempo excedente na administração dos bens patrimoniais sob responsabilidade dos agentes patrimoniais.

10) A FUB deveria fornecer benefícios monetários para incentivar os agentes patrimoniais a terem mais controle e monitoramento sob suas cargas patrimoniais.

11) A FUB deveria fornecer benefícios não monetários para incentivar os agentes patrimoniais a terem mais controle e monitoramento sob suas cargas, tais como: prêmios de qualidade; poder de decisão, prestígio, reconhecimento, etc. 
12) O fácil acesso de pessoas a FUB dificulta o controle dos bens patrimoniais sob a responsabilidade dos agentes patrimoniais.

13) Quanto maior o número de bens móveis, pior é o controle desses bens sob responsabilidade dos agentes patrimoniais.

14) Quanto maior o valor dos bens móveis, maior é o controle e monitoramento desses bens sob responsabilidade dos agentes patrimoniais.

15) Existe acumulo de serviço entre a função para qual se é remunerado e a de agente patrimonial, dificultando assim na administração dos bens que estão sob sua responsabilidade.

16) A estabilidade profissional do servidor público influencia negativamente no controle e monitoramento dos bens móveis sob sua responsabilidade.

17) Existe dificuldade em repassar informações atualizadas sobre os bens patrimoniais que estão sob sua responsabilidade ao setor de patrimônio.

18) Existe insatisfação pessoal no que diz respeito às obrigações que são necessárias na realização da atividade de agente patrimonial.

\section{PERGUNTA ABERTA}

Quais benefícios a FUB poderia oferecer aos seus agentes patrimoniais para estimulá-los no desempenho de suas atividades? 
7.2 Apêndice B - Relatório do Inventário Patrimonial Descentralizado da UnB do ano de 2013

\begin{tabular}{|c|c|c|c|c|c|c|c|c|c|c|c|}
\hline \multicolumn{12}{|c|}{ Relatório do Inventário Patrimonial Descentralizado da UnB do ano de 2013} \\
\hline № & Centro de Custo & $\begin{array}{l}\text { Bens não } \\
\text { localizados }\end{array}$ & $\begin{array}{c}\text { Solicitações de } \\
\text { baixa e } \\
\text { recolhimento de } \\
\text { bens em desuso }\end{array}$ & \begin{tabular}{c|} 
Solicitações de \\
transferências de \\
cargas \\
patrimoniais \\
entre agentes \\
patrimoniais
\end{tabular} & $\begin{array}{c}\text { Ausência de } \\
\text { assinatura dos } \\
\text { agentes patrimoniais } \\
\text { nas suas respectivas } \\
\text { relações de carga } \\
\text { patrimonial }\end{array}$ & $\begin{array}{c}\text { Bens } \\
\text { registrados } \\
\text { no SIPAT, } \\
\text { mas sem a } \\
\text { plaqueta de } \\
\text { identificação } \\
\text { anexada }\end{array}$ & $\begin{array}{l}\text { Bens que } \\
\text { não estão } \\
\text { cadastrados } \\
\text { no SIPAT }\end{array}$ & $\begin{array}{l}\text { Bens cadastrados } \\
\text { no SIPAT com } \\
\text { características } \\
\text { equivocadas }\end{array}$ & $\begin{array}{c}\text { Agentes } \\
\text { patrimoniais } \\
\text { com alocação } \\
\text { equivocada no } \\
\text { SIPAT }\end{array}$ & $\begin{array}{c}\text { Bens } \\
\text { registrado } \\
\text { s no SIPAT } \\
\text { com } \\
\text { alocação } \\
\text { errada }\end{array}$ & $\begin{array}{l}\text { Bens em } \\
\text { processo de } \\
\text { transferênci } \\
\text { a de cargas } \\
\text { patrimoniais }\end{array}$ \\
\hline 1 & ADM & & & & & & & & & & \\
\hline 2 & ALM/PAT & & & & & & & & & & \\
\hline 3 & AUD & & & & & & $\mathrm{x}$ & & & & \\
\hline 4 & BCE & & & & & & & & & & \\
\hline 5 & BOT & & & $x$ & & & & & & & \\
\hline 6 & CAEP & $x$ & & $x$ & $x$ & $\mathrm{x}$ & & & & & \\
\hline 7 & CAL & & & & & & & & & & \\
\hline 8 & CCA & & & & & & & & & & \\
\hline 9 & $\mathrm{CCL}$ & & & & & & & & & & \\
\hline 10 & CDS & & & & & & & & & & \\
\hline 11 & CDT & & & & & & & & & & \\
\hline 12 & CEAD & $x$ & & & $x$ & & & & & & $x$ \\
\hline 13 & CEAM & & & $x$ & & & & & & & \\
\hline 14 & CEDOC & & & & & & & & & & \\
\hline 15 & CEFTRU & & & $x$ & & & & & & & \\
\hline 16 & CEL & & & & & & & & & & \\
\hline 17 & CEN & & & & & & & & & & \\
\hline 18 & CEPLAN & & & & & & & & & & $x$ \\
\hline 19 & CEPPAC & & & $x$ & & & & & & & \\
\hline 20 & CER & & & & & & & & & & \\
\hline 21 & CERME & & & & & & & & & & \\
\hline
\end{tabular}




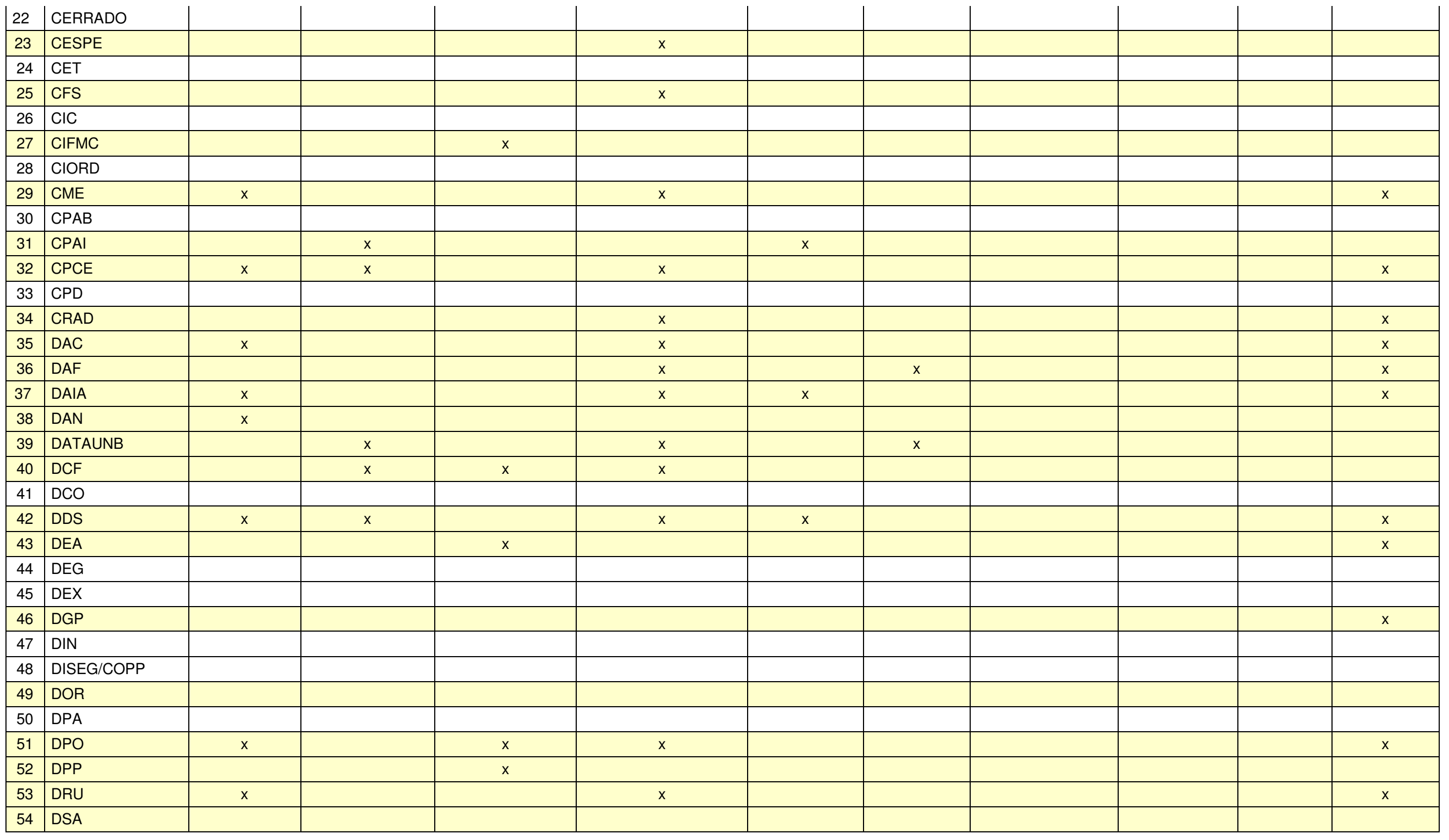




\begin{tabular}{|c|c|c|c|c|c|c|c|c|c|}
\hline 55 & DSC & & & & & & & & $x$ \\
\hline 56 & ECL & $x$ & $x$ & $x$ & $x$ & & $x$ & & $x$ \\
\hline 57 & ECO & $x$ & $x$ & & $x$ & & $x$ & & \\
\hline 58 & EDU & & & $x$ & & & & & \\
\hline 59 & EFL & & & & & & & & \\
\hline 60 & ENC & & & & & & & & \\
\hline 61 & ENE & & & $x$ & & & & & \\
\hline 62 & ENF & & & & & & & & \\
\hline 63 & ENM & & & & & & & & \\
\hline 64 & EST & & $x$ & $x$ & & $x$ & $x$ & & \\
\hline 65 & FAC & & & & $x$ & & & & $\mathrm{x}$ \\
\hline 66 & FACE & & & & & & & & \\
\hline 67 & FAL & & & & & & & & \\
\hline 68 & FAU & & & & $x$ & & & & \\
\hline 69 & FAV & & & & & & & & \\
\hline 70 & FCE & & & & & & & & \\
\hline 71 & $\mathrm{FCl}$ & & & & $x$ & & & & \\
\hline 72 & FDD & & & & & & & & \\
\hline 73 & FED & $x$ & $\mathrm{x}$ & $x$ & & & & & \\
\hline 74 & FEF & & & & $x$ & & & & $x$ \\
\hline 75 & FGA & & & $x$ & $x$ & & & & $x$ \\
\hline 76 & FIL & & & & & & & & \\
\hline 77 & FIT & & & & & & & & \\
\hline 78 & FMD & & & & $x$ & & & & \\
\hline 79 & FSD & & & & & & & & \\
\hline 80 & FTD & & & & $x$ & & & & $x$ \\
\hline 81 & FUP & & & & $x$ & & & $x$ & \\
\hline 82 & GEA & & & & & & & & \\
\hline 83 & GEM & $x$ & & & $x$ & & & & $x$ \\
\hline 84 & GRE & & & $x$ & & & & & \\
\hline 85 & HIS & $x$ & & & $x$ & & & & $\bar{x}$ \\
\hline 86 & HUB & & & & & & & & \\
\hline
\end{tabular}




\begin{tabular}{|c|c|c|c|c|c|c|c|c|c|c|c|}
\hline 87 & |HVET & & & & & & & & & & \\
\hline 88 & IBD & $x$ & & $x$ & $x$ & $x$ & $x$ & & $x$ & $x$ & $\mathrm{x}$ \\
\hline 89 & ICS & $\mathrm{x}$ & & & & & $x$ & & & & \\
\hline 90 & IDA & & & & & & & & & & \\
\hline 91 & IED & $\mathrm{x}$ & & & & & & & & & $\mathrm{x}$ \\
\hline 92 & IFD & & & & & & & & & & \\
\hline 93 & IGD & & & & $x$ & & & & & & \\
\hline 94 & IHD & $\mathrm{x}$ & $x$ & & $x$ & & & & & & \\
\hline 95 & ILD & & & $\mathrm{x}$ & $x$ & & & & & & $\mathrm{x}$ \\
\hline 96 & \begin{tabular}{|l|} 
INTERFOCO \\
\end{tabular} & & & & & & & & & & \\
\hline 97 & IPD & & & & & & & & & & \\
\hline 98 & IPOL & & & $\mathrm{x}$ & & & & & & & \\
\hline 99 & IQD & & & & & & & & & & \\
\hline 100 & IREL & & & & & & & & & & \\
\hline 101 & LET & & & & & & & & & & \\
\hline 102 & LIP & & & & & & & & & & \\
\hline 103 & MAT & & & & $x$ & $x$ & & & & & \\
\hline 104 & MUS & & & & $x$ & & & & & & \\
\hline 105 & NMT & & & & & & & & & & \\
\hline 106 & ODT & & & & & & & & & & \\
\hline 107 & PCL & & & & & & & & & & $x$ \\
\hline 108 & PED & & & & $x$ & & & & & & $\mathrm{x}$ \\
\hline 109 & PJU & $x$ & & & $x$ & X(avariada) & $x$ & $x$ & & & $\mathrm{x}$ \\
\hline 110 & PPB & & & & $x$ & & & & & & $\mathrm{x}$ \\
\hline 111 & PPGA & & & & & & & & & & \\
\hline 112 & PRC & & & & & & & & & & \\
\hline 113 & PST & & & & $x$ & & & & & & \\
\hline 114 & SAA & & & & $x$ & & & & & & $\mathrm{x}$ \\
\hline 115 & SAM & & & & & & & & & & \\
\hline 116 & SCA & & & & & & & & & & \\
\hline 117 & SECOM & & & & & & & & & & \\
\hline
\end{tabular}




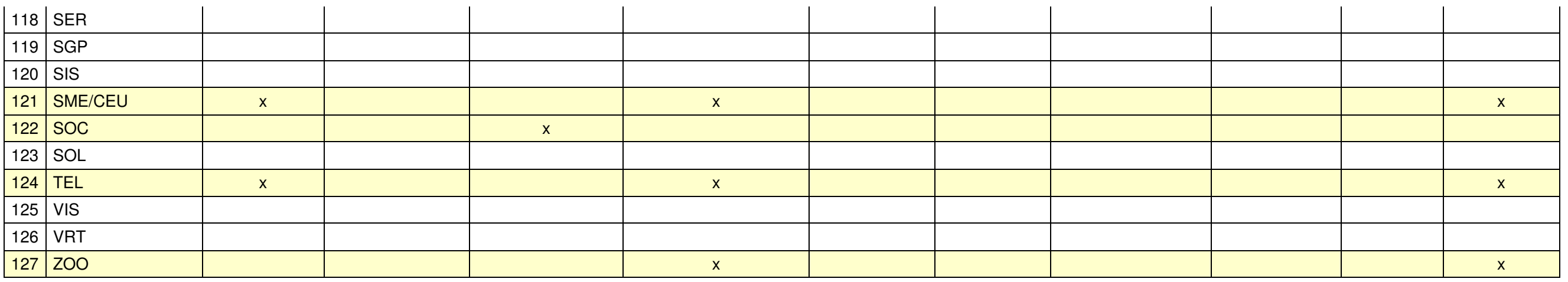

\begin{tabular}{|l|l|}
\hline & $=$ Inventário entregue \\
\hline & $=$ Não entregou Inventário \\
\hline
\end{tabular}


ANEXO A - Circular n 003/2013/DAF

\begin{tabular}{|c|c|c|c|}
\hline$\overline{\text { DATA }}$ & & $\overline{\text { ATIVIDADE }}$ & RESPONSÁVEIS \\
\hline $\begin{array}{l}\text { De } \quad 26 / 08 \\
30 / 08 / 2013\end{array}$ & & $\begin{array}{l}\text { Encaminhamento dos seguintes documentos às } \\
\text { unidades: } \\
\text { - Resolução do DAF via e-mail e UnBDoc } \\
\text { fixando normas e procedimentos referentes à } \\
\text { realização do Inventário Patrimonial } \\
\text { Descentralizado de Bens Móveis no âmbito da } \\
\text { FUB; } \\
\text { - Circular DAF via e-mail e UnBDoc para } \\
\text { indicação das Subcomissões de Inventário por } \\
\text { Unidade Descentralizada. }\end{array}$ & DAF/DGM \\
\hline $\begin{array}{l}\text { De } \quad 26 / 08 \\
20 / 09 / 2013\end{array}$ & $\mathbf{a}$ & $\begin{array}{l}\text { Restituição ao DAF via DGM do UnBDoc com } \\
\text { o memorando do Titular do Centro de Custo } \\
\text { indicando os membros da Subcomissão de } \\
\text { Inventário Patrimonial de cada unidade. }\end{array}$ & \begin{tabular}{|l} 
UNIDADES \\
(Titulares dos \\
Centros de Custo)
\end{tabular} \\
\hline $\begin{array}{l}\text { De } 26 / 08 \\
04 / 10 / 2013\end{array}$ & $\mathbf{a}$ & $\begin{array}{l}\text { Edição e encaminhamento às unidades dos } \\
\text { seguintes documentos: } \\
\text { - Resolução do DAF constituindo as } \\
\text { Subcomissões de Inventário Patrimonial por } \\
\text { unidade descentralizada; } \\
\text {-Resolução do DAF constituindo Comissão } \\
\text { Central de Inventário. }\end{array}$ & DAF/DGM \\
\hline $\begin{array}{l}\text { De } 26 / 08 \\
31 / 12 / 2013\end{array}$ & $\mathbf{a}$ & $\begin{array}{l}\text { Realização das atividades de Inventário pelas } \\
\text { Subcomissões e envio dos relatórios por meio } \\
\text { de memorando registrado no UnBDoc para a } \\
\text { Coordenação de Patrimônio -PAT. }\end{array}$ & $\begin{array}{l}\text { UNIDADES } \\
\text { (Subcomissões) }\end{array}$ \\
\hline $\begin{array}{l}\text { De } 01 / 01 \\
31 / 01 / 2014\end{array}$ & $\mathbf{a}$ & $\begin{array}{l}\text { Análise dos relatórios pela Comissão Central } \\
\text { de Inventário (CCI) envio do Relatório Final à } \\
\text { Diretoria de Contabilidade e Finanças (DCF) e } \\
\text { Auditoria (AUD). }\end{array}$ & CCI/DGM/PAT \\
\hline
\end{tabular}




\title{
ANEXO B - Normas de Registro e Controle de Bens Patrimoniais Móveis da FUB
}

\author{
Setembro de 2004 \\ Conselho Diretor \\ Membros Titulares \\ Professor Lauro Morhy Presidente \\ Antônio Cechelli de Mattos Paiva Membro \\ Carolina Martuscelli Bori Membro \\ Carlos Alberto Rodrigues da Cunha Membro \\ Flávio Rabelo Versiani Membro \\ Inocêncio Mártires Coelho Membro \\ Membros Suplentes \\ Gileno Fernandes Macelino Membro \\ Jacques Rocha Velloso Membro \\ Decano de Administração Erico Paulo Siegmar Weidle \\ Diretor de Recursos Materiais Francisco José Dantas
}

Equipe Técnica:

Eudes de Queiroz e Silva - Chefe do PAT/Serviço de Patrimônio Mobiliário

Hélio Marcos Neiva - Assessor do Conselho Diretor da FUB (Responsável Técnico)

Colaboração:

Nair Aguiar de Miranda - Assessora do Reitor

Professora Geralda Dias Aparecida - Diretora da Casa da Cultura da América Latina Professor José Carlos Andreoli - Diretor do Centro de Documentação

Clarimar Almeida Valle - Diretora da Biblioteca Central 
Ermelina da Silva Paula - Assessora do Reitor e Secretária ad hoc do Conselho Diretor Revisão:

Flávia Ribeiro Machado - Bacharela em Letras pela UnB.

\section{APRESENTAÇÃO}

As Normas de Registro e Controle dos Bens Patrimoniais Móveis, integrantes do Sistema de Gestão do Patrimônio Mobiliário da FUB (SIPAT), têm por finalidade estabelecer normas e procedimentos para regulamentar as atividades relativas ao tombamento, registro, controle, movimentação, baixa e inventário de bens móveis, incluindo os bens culturais, adquiridos pela Instituição, assim como à incorporação ao patrimônio da Fundação Universidade de Brasília dos bens e equipamentos provenientes de doações.

A ideia de congregar em documento único todas as normas internas que tratam da gestão do patrimônio da FUB, considerando os equipamentos, os materiais permanentes e os bens culturais - que exigiram atenção e tratamento especiais, dado a seu valor representativo, histórico e cultural -, visou a otimizar a sistemática de gestão e controle desses bens patrimoniais móveis, facilitando o acesso e o manuseio por parte dos usuários. As presentes normas são amplas em sua aplicação, vez que toda a comunidade da UnB/Universidade de Brasília (órgãos e pessoal) estará a ela submetida.

O órgão responsável pelo controle e acompanhamento das atividades inerentes ao SIPAT é o PAT/Serviço de Patrimônio Mobiliário da DRM/Diretoria de Recursos Materiais da UnB. Nesse processo, é também de fundamental importância o papel a ser desempenhado pela Comissão de Gestão de Bens Culturais, instituída pelo Reitor, formada por servidores do CEDOC/Centro de Documentação, da CAL/Casa da Cultura da América Latina, da BCE/Biblioteca Central, entre outras unidades afins. 
É evidente que nesse Sistema a função dos agentes patrimoniais é da maior relevância, dado que têm a responsabilidade imediata pelos bens que estão sob sua guarda. Entretanto, todos os servidores, indistintamente, têm o dever de zelar pela conservação e manutenção dos bens móveis da Instituição, sujeitando-se às penalidades previstas na Lei n. 8.429/1992, na hipótese de lesão ao patrimônio público, por ação ou omissão, dolosa ou culposa. Por outro lado, a responsabilidade sobre a guarda e conservação do patrimônio institucional é atribuição, também, de estudantes e pesquisadores vinculados, a qualquer título, à Universidade.

Assim, é necessário que as presentes normas sejam amplamente divulgadas no âmbito das Unidades, de forma que todos os servidores integrantes da força de trabalho, membros temporários e permanentes da Academia, tenham conhecimento do seu conteúdo, cumpramnas e façam-nas ser cumpridas com rigor.

Erico Paulo Siegmar Weidle

Decano de Administração

Anexo à Resolução n. 17/2004, do Conselho Diretor da FUB.

\section{NORMAS DE REGISTRO E CONTROLE DE BENS PATRIMONIAIS MÓVEIS DA FUB}

\section{CAPÍTULO I - Das Disposições Gerais}

Art. 1o Este documento cria Normas de Registro e Controle de Bens Patrimoniais Móveis, constituídos por equipamentos e material permanente e por bens culturais, integrantes do Sistema de Gestão do Patrimônio Mobiliário da FUB, define as Unidades que o integram, os seus agentes e gestores, bem como a responsabilidade de cada um, no que diz respeito ao registro, controle, guarda, conservação, movimentação, baixa e ao inventário do patrimônio institucional, de conformidade com o Estatuto da FUB.

Parágrafo único. Para efeito deste documento, consideram-se: 
I. como equipamentos e material permanente: máquinas e equipamentos mecânicos, hidráulicos, elétricos, eletrônicos, agrícolas, rodoviários, gráficos, de processamento de dados, de comunicação, de oficina, de áudio, vídeo e foto; aeronaves, embarcações e veículos terrestres; equipamentos, máquinas, aparelhos e utensílios de uso laboratorial; equipamentos de medição, orientação, mergulho, proteção, segurança, socorro e salvamento; coleções, periódicos e outros materiais bibliográficos,

discotecas e filmotecas; instrumentos musicais e artísticos; aparelhos e utensílios domésticos, de escritório e mobiliário em geral; semoventes;

II. como bens culturais: obras de arte, constituídas, entre outras, por pinturas, desenhos, gravuras, serigrafias, esculturas e outros artefatos culturais; peças para museu; obras raras da Biblioteca Central da UnB.

Art. $2^{\text {o }}$ Integram o Sistema de Gestão do Patrimônio Mobiliário da FUB as seguintes Unidades: o Serviço de Patrimônio Mobiliário da Diretoria de Recursos Matérias, o Centro de Informática, o Centro de Manutenção de Equipamentos Científicos, a Casa da Cultura da América Latina, o Centro de Documentação e a Biblioteca Central, com atribuições específicas, e todos os demais Centros de Custo da FUB.

Art. 3o As normas estabelecidas neste documento são aplicáveis a todas as Unidades Acadêmicas e Administrativas, Órgãos Complementares e Centros, assim como a todos os servidores técnico-administrativos e docentes da FUB e, no que couber, aos alunos, pesquisadores, prestadores de serviços à FUB e aos parceiros institucionais.

Art. 4o Todos os membros da comunidade universitária têm o dever de zelar pelos bens patrimoniais da Instituição. Parágrafo único. Toda pessoa que tiver conhecimento de fatos ou indícios de roubo, furto, extravio, danos ou uso indevido, por qualquer forma, de bens patrimoniais da Instituição tem o dever de comunicar tal ocorrência ao Serviço de Patrimônio, por intermédio do Agente Patrimonial, sob pena de ser responsabilizado por negligência, 
omissão ou conivência, sujeitando-se às penalidades cabíveis na legislação em vigor e nestas normas.

Art. 5o As presentes normas aplicam-se aos bens móveis das seguintes categorias:

I. bens da FUB;

II. bens cedidos à FUB, mediante doação, por pessoas físicas ou jurídicas, ou por meio de comodato;

III. bens resultantes de contratos de locação ou decorrentes de serviços, utilizados em atividades da FUB.

Art. 6o Aos bens de terceiros, desde que não inclusos no art. 5o, sejam esses de servidor da FUB, alunos de todas as categorias ou qualquer tipo de pessoa física ou jurídica, não se aplicam as presentes normas.

CAPÍTULO II - Do Sistema de Gestão do Patrimônio Mobiliário

Art. 7o O SIPAT compreende as atividades de tombamento, registro, guarda, controle, movimentação, preservação, baixa, incorporação e inventário de bens móveis, provenientes de aquisição no mercado interno e externo, e de doações, que incorporam o acervo patrimonial móvel da FUB, assim como a indicação de servidores como agentes patrimoniais, no âmbito da UnB.

Art. 8o O PAT é o órgão gestor central e responsável pelo Sistema, ao qual compete efetuar o controle e o acompanhamento das atividades inerentes ao Sistema, além daquelas definidas especificamente neste documento.

Art. 9o Compete ao CPD dar o suporte técnico permanente necessário à manutenção e atualização do Sistema.

Art. 10. Compete ao CME, além da função básica de manutenção e reparos de equipamentos, emitir laudo de vistoria, para efeito de baixa patrimonial ou redistribuição, ouvida, previamente, a PJU/Procuradoria Jurídica. 
Art. 11. Compete à CAL o registro, a manutenção, a preservação, o controle, a gestão e a divulgação das obras de arte que estão sob sua guarda.

Art. 12. Compete ao CEDOC organizar, preservar e divulgar o acervo documental da FUB, englobando a pesquisa de novas tecnologias nas áreas de microfilmagem, digitalização, preservação e restauração de documentos e obras de arte.

Parágrafo único. É de responsabilidade do CEDOC, em conjunto com a CAL, elaborar e manter atualizado o catálogo das peças integrantes dos bens culturais da FUB, de maneira a facilitar o acesso às informações a eles pertencentes, tanto pela comunidade universitária, quanto pela sociedade em geral.

Art. 13. Compete à BCE o registro, a catalogação, a guarda, a conservação, a preservação, a gestão e a divulgação das obras raras daquela Biblioteca, desenvolvendo e implantando mecanismos adequados de controle que assegurem a integralidade de tais obras, em eventuais consultas.

Art. 14. Compete à Comissão de Gestão de Bens Culturais, instituída pelo Reitor, composta por servidores da CAL, do CEDOC e da BCE, entre outras Unidades, propor diretrizes relacionadas à gestão do patrimônio cultural da FUB, notadamente, no que diz respeito à sistemática de registro, classificação, catalogação, tombamento, guarda, manuseio, avaliação, manutenção, preservação e adequado controle dos bens culturais da FUB.

$\S 1$ o A responsabilidade pela guarda e preservação de bens culturais localizados em outros Centros de Custo é de competência direta dos respectivos agentes patrimoniais, observadas as diretrizes definidas pela Comissão de Gestão de Bens Culturais.

$\S 20$ O planejamento, organização e execução de exposições de obras de arte ou outros bens culturais da FUB são de responsabilidade dos Centros de Custo que detêm sua guarda, observadas as diretrizes definidas pela Comissão.

CAPÍTULO III - Do Tombamento, Registro e Controle de Bens Móveis 
Art. 15. Todo bem - equipamento, material permanente e bens culturais - adquirido pela FUB, por meio do SCN/Serviço de Compras Nacionais ou do SCI/Serviço de Compras Internacionais da DRM, ou recebido mediante doação - deverá dar entrada no SAL/Serviço de Almoxarifado Central, para efeito de tombamento e demais registros.

Parágrafo único. Quando se tratar de bens culturais, devem ser observadas as diretrizes específicas a respeito, estabelecidas pela Comissão de Gestão de Bens Culturais.

Art. 16. As aquisições de equipamentos e materiais permanentes ou bens culturais efetuadas diretamente pelas Unidades Gestoras Descentralizadas deverão obedecer aos seguintes procedimentos:

I. o bem deverá ser entregue no local determinado na Nota de Empenho;

II. o servidor responsável pelo recebimento do bem deverá atestá-lo no verso da Nota fiscal, devendo armazená-lo em local apropriado, sob sua responsabilidade, até o respectivo tombamento pelo PAT;

III. a Nota Fiscal (original) e o respectivo Empenho deverão ser encaminhados ao SAL, para emissão de Nota de Fornecimento de Material e posterior envio ao PAT para classificação e tombamento;

IV. o PAT procederá à classificação contábil e tombamento do material, enviando à Unidade Gestora, por meio de mapa, a documentação recebida do SAL, para pagamento, observandose o disposto no artigo 14, quando se tratar de bens culturais;

V. o pagamento e a distribuição do bem somente poderão ocorrer após o devido tombamento e classificação da Nota Fiscal pelo PAT;

VI. a Unidade Gestora Descentralizada obriga-se a enviar mensalmente ao PAT relatório das aquisições. 
$\S$ 1o O PAT encaminhará, trimestralmente, à DCF/Diretoria de Contabilidade e Finanças o Relatório de bens adquiridos pelas Unidades Descentralizadas, para fins de compatibilização das aquisições patrimoniais com os respectivos registros contábeis.

$\S 20$ Quando se tratar de material de grande porte, em grande quantidade ou que necessite de montagem, a Unidade Gestora deverá comunicar ao PAT a localização e o responsável pelo material, observando-se o disposto no artigo 14, no caso de bens culturais.

Art. 17. Para todo bem móvel produzido na FUB deverá ser emitido, pela unidade fabricante, o formulário Guia de Produção Industrial.

Art. 18. Concluída a produção de cada bem móvel, a unidade fabricante encaminhará a documentação concernente ao PAT, para que sejam procedidos o tombamento, o registro, a classificação contábil e a emissão do Termo de Responsabilidade Patrimonial, antes de sua distribuição ao usuário.

Parágrafo único. A inobservância do disposto no caput deste artigo implicará a responsabilização do servidor que lhe der causa.

Art. 19. Quando se tratar de obra de arte criada no âmbito da FUB e que venha a integrar seu acervo cultural, a unidade produtora encaminhará a documentação concernente ao PAT, para que sejam procedidos o tombamento, o registro, a classificação contábil e a emissão do Termo de Responsabilidade Patrimonial, antes de sua distribuição ao local de destino, segundo as diretrizes definidas pela Comissão de Gestão de Bens Culturais.

CAPÍTULO IV - Do Agente Patrimonial Delegado e do Termo de Responsabilidade

Art. 20. Agente Patrimonial Delegado é todo servidor indicado pelo titular da Unidade ou Subunidade e designado por ato do DAF/Decanato de Administração como responsável imediato por bens móveis da FUB, inclusive bens culturais, mediante a assinatura de Termo de Responsabilidade Patrimonial e Relação de Carga Patrimonial. 
$\S 1$ o Os servidores investidos em função de chefia, direção e assemelhados têm responsabilidade pelo acervo patrimonial pertencente ao seu Centro de Custo, sem prejuízo da responsabilidade imediata do Agente Patrimonial, mediante os respectivos termos de responsabilidade.

§ 2o O Titular da Unidade - Diretor, Decano, Secretário (SPL, SRH, SGP, SEI, EMP), Chefes de Assessorias e Chefe de Auditoria - é o Agente Patrimonial Nato.

$\S 30$ O Titular da Subunidade - Chefe de Departamento ou de Serviço - é o Subagente Patrimonial Nato.

$\S 40$ Somente poderá ser Agente Patrimonial servidor pertencente ao Quadro de Pessoal da FUB ou servidor público cedido à FUB.

Art. 21. O Agente Patrimonial Delegado será o responsável direto pela prestação de contas, zelo e integridade do bem sob sua utilização direta.

$\S 1$ E É dever do Agente Patrimonial Delegado comunicar imediatamente ao seu substituto ou ao Titular da Subunidade (Subagente Patrimonial Nato) ou ao Titular da Unidade (Agente Patrimonial Nato) - quando for diretamente subordinado a esse - qualquer irregularidade ocorrida com o equipamento, material permanente ou bem cultural entregue aos seus cuidados.

§ 2o Todo e qualquer servidor ou prestador de serviços pode ser responsabilizado pelo desaparecimento ou dano de bens patrimoniais que lhe forem confiados para uso.

Art. 22. O Agente Patrimonial Delegado será o responsável pela vistoria permanente, solicitações de manutenção, fiscalização do uso, controle interno, comunicação de movimentação e irregularidade relativas aos bens de sua carga patrimonial.

$\S 1$ lo É dever do Agente Patrimonial Delegado comunicar, imediatamente e por escrito, à COPP/Coordenação de Proteção ao Patrimônio qualquer irregularidade ocorrida com o acervo patrimonial sob sua responsabilidade, que resulte em desaparecimento, depredação, 
danificação ou sinistro, enviando cópia para a Comissão de Gestão de Bens Culturais, quando se tratar de bem cultural.

$\S 2$ o O documento básico para ensejar exame do material ou averiguação de causas da irregularidade ocorrida com o bem será o expediente circunstanciado, exarado pelo Agente Patrimonial Delegado, ou constatação, in loco, sem prejuízo de participações verbais que, informalmente, antecipam a ciência pela COPP.

Art. 23. O Agente Patrimonial Delegado será indicado pelo Titular do Centro de Custo (Unidade ou Subunidade) de lotação do servidor e designado por ato do DAF.

Art. 24. Para cada local definido na Unidade, só poderá haver um Agente Patrimonial indicado, o qual poderá, ainda, ser responsável por mais de um local no Centro de Custo ou em Centro de Custo diferente.

Parágrafo único. Para efeito da aplicação destas normas, entenda-se como local cada dependência do Centro de Custo.

Art. 25. O Termo de Responsabilidade de Carga Patrimonial da FUB, descentralizado por Unidade/agente patrimonial/local, é representado por um dos seguintes formulários: Relação de Carga Patrimonial por Agente; Termo de Responsabilidade Patrimonial (Alocação Inicial, Transferência Parcial, Transferência Total); e Termo de Cessão em Comodato.

Art. 26. A Relação de Carga Patrimonial por Agente será expedida exclusivamente pelo PAT, sempre que houver incorporação, transferência entre unidades e/ou agentes, reestruturação organizacional de unidade, por ocasião do inventário anual, implicando a redistribuição da responsabilidade de carga patrimonial.

Art. 27. O Termo de Responsabilidade Patrimonial será expedido sempre que houver incorporação, transferência de bens entre Unidades e/ou agentes, devendo ser assinado pelo respectivo Agente Patrimonial, imediatamente após a sua apresentação na Unidade depositária, e nele devem ser apostos o carimbo e a matrícula. 
Art. 28. No impedimento ou inexistência de Agente Patrimonial Delegado, o Termo de Responsabilidade Patrimonial deverá ser assinado pelo titular do Centro de Custo, que posteriormente enviará documento ao PAT, solicitando a transferência de responsabilidade da carga ao Agente Patrimonial devidamente indicado por ele.

Art. 29. O Termo de Responsabilidade Patrimonial e a Relação de Carga Patrimonial por agente só poderão ser assinados por servidor da FUB ou por servidor cedido à FUB.

CAPÍTULO V - Da Delegação de Competência e Transferência de Responsabilidade

Art. 30. Caberá ao Titular da Subunidade, na condição de Subagente Patrimonial Nato, ou ao Titular da Unidade, na condição de Agente Patrimonial Nato, quando for o caso, tomar todas as providências administrativas cabíveis, no sentido de garantir o controle do acervo patrimonial de sua Subunidade ou Unidade.

§1o Havendo necessidade de delegação de responsabilidade, compete ao Titular da Subunidade ou Unidade a indicação de Agente Patrimonial Delegado, em número que julgar necessário para garantir o controle eqüitativo e eficaz do acervo da unidade, permanecendo co-responsável pela carga patrimonial de sua Unidade.

§ 2o O Titular da Subunidade ou Unidade deverá informar o nome, a matrícula e a lotação do agente indicado, assim como a descrição detalhada do local cujos bens estejam sob a sua responsabilidade.

Art. 31. A transferência de responsabilidade por carga patrimonial ocorrerá quando houver:

I. extinção, transformação, reestruturação ou criação de Unidade;

II. desvinculação de cargo, função ou emprego de servidores;

III. remoção, transferência e redistribuição de servidor, que exijam nova indicação;

IV. óbito do servidor.

Parágrafo único. A transferência de responsabilidade por carga patrimonial sempre será efetuada após o levantamento físico dos bens patrimoniais. 
Art. 32. Na transferência de responsabilidade por carga patrimonial, só será considerado sem débito o agente patrimonial que fizer o levantamento físico da carga e providenciar o envio de documento ao PAT com o "de acordo" pelo recebimento da carga, exarado pelo Agente Patrimonial Substituto e após assinatura do Termo de Responsabilidade.

Parágrafo único. O descumprimento do disposto neste artigo determinará a inadimplência do Agente Patrimonial Delegado, inviabilizando processo de desvinculação de cargo, função ou emprego e determinando débito patrimonial para com a FUB.

Art. 33. Em todo processo de desligamento ou afastamento de servidores da FUB deverá constar o formulário de consulta de débito de carga patrimonial emitido, on-line, pela Secretaria de Recursos Humanos, por meio do SIPAT.

Parágrafo único. Todo processo de desligamento ou afastamento de servidores do Ministério da Saúde, cedidos ao HUB, deverá gerar consulta do Setor de Recursos Humanos do HUB ao PAT, para verificação de débito patrimonial, antes da efetivação do processo.

Art. 34. As substituições ou interinidades de agente patrimonial devem ser comunicadas formalmente ao PAT, pelas unidades, com a indicação do Agente Patrimonial Substituto.

CAPÍTULO VI - Da Movimentação de Bens Móveis

Art. 35. A movimentação de bens móveis da FUB dar-se-á por:

I. empréstimo;

II. exposição pública, por iniciativa de órgão responsável por sua guarda, no caso de bens culturais;

III. transferência de carga patrimonial;

IV. necessidade de seu reparo e manutenção pelo CME ou de seu deslocamento à PRC/Prefeitura do Campus ou para fora do Campus, quando se tratar de equipamentos em garantia ou de equipamentos cujos reparos comprovadamente não possam ser realizados pelo CME. 
$\S 1$ o Os bens culturais da FUB poderão ser cedidos, por empréstimo temporário, a pessoas jurídicas, públicas ou privadas, mediante o cumprimento dos seguintes requisitos:

I. a entidade interessada deverá formalizar o pedido de empréstimo à Unidade detentora da carga patrimonial do bem, no qual constem, obrigatoriamente: a identificação dos bens, a finalidade a que se destinam e o prazo do empréstimo;

II. aprovado o pedido, segundo as diretrizes da Comissão de Gestão de Bens Culturais, a unidade exigirá, do tomador do empréstimo, a assinatura de Termo de Responsabilidade, mediante o qual serão asseguradas à Instituição as garantias adequadas à integridade e conservação das peças e

definidos o prazo, a forma de utilização e a responsabilização por perda, avaria ou pelo eventual mau uso do bem, assim como a aplicação de multa por atraso na sua devolução;

III. é obrigatória a exigência de caução, seguro ou outra garantia fiduciária, quando se tratar de empréstimo de bens de grande valor, em termos quantitativos, qualitativos ou de importância histórico-cultural;

IV. após a aprovação pela unidade, o pedido será encaminhado ao PAT, juntamente com o Termo de Responsabilidade assinado, para efeito de controle e emissão da Guia de Empréstimo Externo, a qual deverá ser assinada pela DRM, pela unidade detentora do bem e pelo solicitante.

$\S 2$ o No caso de obras raras, livros e periódicos, devem ser observadas as particularidades das normas específicas a respeito, baixadas pela BCE.

Art. 36. Quando se tratar de transferência de bem ou de carga patrimonial entre agentes e/ou Centros de Custos, compete à unidade responsável pelo bem solicitar sua movimentação, online, via SIPAT, na tela "Solicita Movimentações".

Parágrafo único. A transferência somente será efetivada após a emissão e assinatura do Termo de Responsabilidade pelo PAT e assinatura dos Agentes Remetente e Recebedor. 
Art. 37. Quando se tratar de transferência de bens móveis para o Depósito do PAT, por não mais ser do interesse da unidade detentora da carga patrimonial, devem ser observados os seguintes procedimentos:

a) no caso de equipamentos, os bens deverão ser obrigatoriamente inspecionados pelo CME;

b) no caso de bens culturais, tais bens deverão ser obrigatoriamente inspecionados pela CAL;

c) a solicitação de inspeção deverá ser efetuada on-line, via SIPAT, na tela "Solicitação de Inspeção" para baixa ou redistribuição de bens.

Art. 38. É de exclusiva competência do PAT emitir Termos de Responsabilidade sobre Transferência de Bens Móveis entre agentes ou Unidades da FUB.

Art. 39. Quando se tratar de empréstimo de bens entre os agentes ou Unidades da FUB, assim como a alunos, pesquisadores, conferencistas ou quaisquer prestadores eventuais de serviços, por interesse da Instituição, compete ao Titular da Unidade responsável pelo bem a emissão, on-line, da Guia de Empréstimo, via SIPAT - função "Movimentação - Solicita Movimentação" - devendo o tomador do empréstimo assinar Termo de Responsabilidade específico, mediante o qual serão asseguradas à Instituição as garantias adequadas pela integridade e conservação dos bens e definidos o prazo, a forma de utilização e a responsabilização por perda, avaria ou pelo eventual mau uso do bem, por parte do responsável pelo empréstimo, segundo controle da própria Unidade, encaminhando ao PAT a terceira via, devidamente assinada.

§1o Os empréstimos, no âmbito da FUB, deverão ser controlados obrigatoriamente pelo Agente Patrimonial da Unidade cedente, a quem cabe a responsabilidade imediata pelo bem, com autorização do Titular da Unidade, devendo-se dar ciência à Comissão de Gestão de Bens Culturais, no caso de bens culturais.

$\S 2$ o É vedado o empréstimo de bens por tempo indeterminado. 
$\S 30$ Quando se tratar de empréstimo de bens a alunos, devem ser observados os procedimentos específicos estabelecidos no artigo 40 .

Art. 40. Havendo a necessidade de ceder, por empréstimo, bens a membros do corpo discente da UnB, imprescindíveis à realização de atividades fora do Campus Universitário, em horário extra-aula e relacionadas a projetos ligados às disciplinas ministradas pela Instituição, o aluno deve preencher Termo de Responsabilidade específico, juntamente com o professor orientador.

$\S 1$ o O Termo de Responsabilidade deverá conter necessariamente:

I. nome do aluno e número de matrícula;

II. descrição do projeto a ser desenvolvido;

III. nome do professor orientador;

IV. relação dos objetos emprestados, com o respectivo número do patrimônio;

V. cláusula de compromisso de devolver os objetos nas mesmas condições de uso em que foram recebidos;

VI. cláusula de compromisso de utilizar os objetos apenas para os fins a que se destinam;

VII. cláusula de responsabilidade pelo ressarcimento de eventuais danos causados ao patrimônio da FUB;

VIII. prazo de duração do empréstimo;

IX. assinatura do aluno;

X. assinatura do professor orientador, atestando a existência do projeto e que esse se encontra em desenvolvimento, assim como que é orientador do aluno e que o equipamento tem utilidade para a realização de atividade atinente ao projeto.

$\S 2$ o Findo o prazo estipulado, os objetos deverão ser entregues ao departamento responsável, que anotará, na presença do aluno, o estado em que eles foram devolvidos. 
§ 3o Caso os objetos não sejam devolvidos na data estabelecida, será fixada multa no valor de $0,01 \%$, por dia de atraso, calculada sobre o valor atualizado dos bens.

$\S 4$ o Salvo hipótese de caso fortuito ou força maior, devidamente comprovada e reconhecida pela UnB, o aluno responderá integralmente pelos danos, furto ou extravio do bem emprestado.

$\S 5$ o Quando se tratar de empréstimo feito conjuntamente por professor e aluno, ambos serão considerados corresponsáveis pelos objetos emprestados, respondendo civilmente de forma solidária.

§ 6o É facultada à Unidade responsável pelo empréstimo dos bens a exigência de caução ou outra garantia fiduciária, especialmente quando se tratar de bens de fácil sumiço, como câmeras fotográficas, câmeras de vídeo, computadores portáteis, entre outros.

$\S 7$ o Além das medidas necessárias ao ressarcimento da FUB, poderão ser aplicadas ao membro do corpo discente as sanções de advertência, ou, se for o caso, repreensão, nos termos do Regimento Disciplinar.

Art. 41. Quando se tratar de empréstimo de bens móveis, para órgãos ou instituições externas, compete à unidade detentora do bem encaminhar o pedido de empréstimo à DRM, via Gabinete do Reitor, para avaliação do pleito.

Parágrafo único. Após a aprovação pela DRM, o pedido será encaminhado ao PAT, que efetuará o controle e a emissão da Guia de Empréstimo Externo, a qual deverá ser assinada pela DRM, pela unidade detentora do bem e pelo solicitante.

Art. 42. Quando se tratar de equipamentos para reparo, compete à unidade detentora da carga patrimonial solicitar, on-line, via SIPAT, na tela "Solicitação de Reparo de Equipamentos FUB”, os reparos necessários, junto ao CME.

Art. 43. Quando se tratar de mobiliário em geral para conserto, compete à Unidade detentora da carga patrimonial a emissão da Guia de Solicitação de Reparos para a PRC, que 
providenciará os reparos in loco ou removerá o bem para a Carpintaria, quando for o caso, encaminhando ao PAT, semestralmente, nos meses de junho e novembro, o relatório dos bens movimentados.

\section{CAPÍTULO VII - Do Desaparecimento e Depredação de Bens Móveis}

Art. 44. O desaparecimento de um bem patrimonial móvel - total ou parcial -, por furto, roubo, depredação ou qualquer outro sinistro, deverá de imediato ser comunicado, pelo Agente Patrimonial Delegado, à COPP e à Comissão de Gestão de Bens Culturais, quando se tratar de bens culturais, observando-se os seguintes encaminhamentos e providências:

I. a COPP deverá registrar a ocorrência em livro próprio e emitir Extrato de Ocorrência, enviando-o ao Centro de Custo ao qual o bem pertence;

II. a COPP encaminhará ofício ao Departamento de Policia Federal - Delegacia de Prevenção e Repressão a Crimes Fazendários - solicitando providências;

III. o comunicante ou o Titular da Subunidade ou da Unidade deverá montar processo nesse sentido, encaminhando-o, via SCA/Subsecretaria de Comunicação Administrativa, à VRT/Vice-Reitoria - Comissão Disciplinar Permanente -, com cópia do processo para o PAT e para a Comissão de Gestão de Bens Culturais, quando se tratar de bens culturais;

Art. 45. O processo, acompanhado de parecer conclusivo da Comissão de Sindicância, deverá ser encaminhado ao PAT, para as providências que se fizerem necessárias.

$\S$ 1o No caso de parecer pela reposição ou recuperação do bem pelo responsabilizado, devidamente homologado pela autoridade competente na FUB, ouvida a Comissão de Gestão de Bens Culturais, quando se tratar de bem cultural, o processo deverá ser encaminhado ao PAT, que expedirá comunicação oficial estipulando o prazo de 30 dias, a contar da data do recebimento, para as providências necessárias.

$\S 2$ o No caso de parecer pela baixa patrimonial, devidamente homologado pela autoridade competente, ouvida a Comissão de Gestão de Bens Culturais, quando se tratar de bem 
cultural, - depois de esgotadas todas as possibilidades de apuração de responsabilidades, visando à reposição do bem, com a conseqüente garantia de integridade do acervo patrimonial da FUB -, o processo deverá ser encaminhado ao PAT, que o instruirá para ser homologado pelo Reitor.

Art. 46. O bem reposto pelo responsabilizado ficará no depósito patrimonial da FUB, em local e em condições adequadas, até que se encerrem os procedimentos administrativos para os registros de controle no PAT.

CAPÍTULO VIII - Do Saneamento e Baixa de Equipamentos

Art. 47. O CME, por solicitação de qualquer Centro de Custo ou por ocasião do reparo de equipamento, fará vistoria do bem, procedendo da seguinte forma:

I. emite parecer técnico, justificando a total impossibilidade de recuperação ou a inviabilidade econômica de reparo do equipamento;

II. emite laudo técnico, sugerindo ao PAT a baixa patrimonial do bem, enviando cópia do referido documento ao Centro de Custo, fazendo constar, da citação, as partes, peças, periféricos ou componentes do equipamento a ser baixado, para efeito de aproveitamento na recuperação de outros equipamentos.

$\S 1$ 1o Para os equipamentos que se encontrarem em reparo no CME, o Centro de Custo interessado poderá diligenciar ou indicar alternativas que viabilizem a sua recuperação, desde que o custo dos

serviços não ultrapasse o limite de $50 \%$ (cinqüenta por cento) do seu valor de mercado, de acordo com a Instrução Normativa SEDAP n. 205/1988.

$\S 2$ o Esgotadas as alternativas que poderiam viabilizar a recuperação do equipamento, o CME disponibilizará, na tela "Manutenção do SIPAT - Andamento da Manutenção", mensagem de indicação da baixa patrimonial do equipamento, constando, inclusive, o número do Laudo de Vistoria, contendo justificativas da tomada de decisão. 
§ 3o O PAT formalizará o processo de baixa, por alienação, o qual será submetido à consideração do Reitor, para a respectiva homologação.

§ 4o Após a homologação, o processo de baixa será devolvido ao PAT, para os devidos registros patrimoniais.

$\S 5$ o Caberá ao CME manter em estoque as peças, partes ou componentes retirados dos equipamentos baixados, bem como lhes atribuir valor com base em pesquisa a ser realizada no mercado, mencionando-se o número do tombamento do bem de onde se retirou a peça ou componente.

Art. 48. O CME solicitará ao PAT o devido registro patrimonial, nos seguintes casos:

I. quando alguma peça, parte ou componente for classificado como "Material Permanente";

II. quando alguma peça, parte ou componente vier originar outro "Equipamento".

Art. 49. Quando as peças, parte ou componentes não se enquadrarem no inciso II do art. 48, serão classificados como peças de "Reposição" (material de consumo).

Art. 50. Os equipamentos serão classificados na forma abaixo:

I. ocioso, quando não estiver sendo aproveitado, mesmo estando em perfeitas condições;

II. antieconômico, quando a sua manutenção for onerosa ou seu rendimento, precário, em virtude de uso prolongado, desgaste prematuro ou estar obsoleto;

III. avariado e recuperável, quando o somatório das despesas envolvidas orçar menos que $50 \%$ (cinqüenta por cento) do seu valor estimado no mercado;

IV. irrecuperável, quando não mais puder ser utilizado para o fim a que se destina, devido à perda de suas características ou em razão da inviabilidade econômica de sua recuperação, e quando o somatório das despesas envolvidas orçar mais que 50\% (cinqüenta por cento) do seu valor estimado no mercado;

V. descontinuado, quando não forem disponibilizados, no mercado ou pelo fabricante do equipamento, peças, partes, componentes ou periféricos que viabilizem a sua recuperação. 


\section{CAPÍTULO IX - Da Baixa Patrimonial de Bens Móveis}

Art. 51. Será procedida a baixa patrimonial de veículo automotor, mobiliário, utensílios de escritório, quando houver desaparecimento ou alienação.

$\S 1$ o Quando se tratar de equipamento, a baixa será procedida na forma prevista no Capítulo VIII deste documento.

$\S 2$ o A baixa patrimonial por desaparecimento será procedida conforme estabelecido no Capítulo VII deste documento.

§ 3o Para efeito de aplicação do disposto no caput deste artigo, haverá de se esgotar todas as possibilidades de apuração de responsabilidades, visando à reposição do bem com a conseqüente garantia da integridade do acervo patrimonial da FUB.

Art. 52. Será procedida a baixa patrimonial de bens culturais, quando houver desaparecimento, permuta ou doação.

$\S$ 1o A baixa patrimonial por desaparecimento será procedida conforme estabelecido no Capítulo VII deste documento.

$\S 20$ O processo de baixa patrimonial por permuta ou doação, quando previamente autorizada pelo Reitor, ouvida a Comissão de Gestão de Bens Culturais, será iniciado mediante solicitação formal de baixa de bem artístico-cultural, emitida pela unidade responsável por sua guarda e dirigida à referida Comissão, que expedirá laudo técnico a ser homologado por Ato da Reitoria.

§ 3o Após a homologação, o processo de baixa será devolvido ao PAT, para os devidos registros patrimoniais.

Art. 53. A baixa patrimonial de bens móveis, por alienação será procedida mediante processo instruído pelo PAT, observadas as disposições do art. 55 deste documento. 
Parágrafo único. Para efeito de aplicação do disposto no caput deste artigo, entenda-se por processo de alienação de bem móvel a transferência do direito de propriedade mediante venda, permuta ou doação.

Art. 54. Adotar-se-á a alienação quando o bem móvel for considerado ocioso, antieconômico ou irrecuperável, conforme classificação especificada no art. 50 deste documento.

Art. 55. O processo de baixa patrimonial por alienação será iniciado mediante solicitação formal de baixa de bem móvel, emitida pela unidade responsável e dirigida ao órgão de manutenção competente, que expedirá laudo técnico a ser homologado por Ato da Reitoria.

\section{CAPÍTULO X - Da Doação de Bens Móveis à FUB}

Art. 56. Antes de dar início ao processo de doação de bens móveis à FUB, o Centro de Custo interessado deverá dirigir-se ao PAT, que o instruirá quanto aos procedimentos adequados.

Art. 57. Todos os documentos relativos à doação deverão ser encaminhados ao PAT, com cópia para a Comissão de Gestão de Bens Culturais, quando se tratar de bens culturais, os quais comporão o processo de doação à FUB, encaminhando-o ao Gabinete do Reitor, para aceitação, mediante a emissão de Ato da Reitoria incorporando o bem ao acervo patrimonial da Fundação.

Art. 58. O processo de doação de bens à FUB, por pessoas físicas ou jurídicas, estará concluso somente após o aceite oficial por parte do Reitor ou outra autoridade delegada, mediante a assinatura do Termo de Doação/Cessão, ouvida, previamente, a PJU e a emissão de Ato da Reitoria incorporando o bem.

$\S$ 1o No Termo de Doação deverá constar, obrigatoriamente: a identificação e assinatura do doador, a especificação, quantidade dos bens e respectivos valores.

$\S 2$ o No caso de doação de bens móveis por fundação de apoio ou entidade assemelhada, o Termo de Doação somente poderá ser assinado após o cumprimento das seguintes exigências: I. que o bem esteja previamente identificado e tombado (plaquetado) pela entidade de apoio; 
II. que a entidade de apoio indique a localização precisa do bem e o nome do responsável por sua guarda e manutenção;

III. que a entidade de apoio apresente documento comprobatório da entrega do bem a servidor da FUB;

IV. que o bem esteja devidamente tombado pelo PAT/FUB e atribuída a respectiva carga patrimonial;

V. que o Termo de Doação seja entregue à FUB no prazo máximo de 30 dias, após a emissão da nota fiscal, respeitados os prazos contratuais.

Art. 59. Os bens doados deverão dar entrada na FUB por intermédio do Depósito do PAT, onde serão tombados, e, após a assinatura do respectivo Termo de Responsabilidade Patrimonial, serão distribuídos ao(s) Centro(s) de Custo interessado(s).

$\S 1$ 1o Os bens culturais doados deverão dar entrada na FUB por intermédio da CAL, que, em conjunto com o PAT, fará a avaliação, classificação, catalogação e tombamento dos bens para, após a assinatura do respectivo Termo de Responsabilidade Patrimonial, serem distribuídos ao(s) Centro(s) de Custo onde ficarão expostos.

§ 2o Quando, em razão de seu volume, tamanho ou peso, ou por necessidade exclusiva de trabalho, os bens doados tiverem de ser recebidos diretamente no Centro de Custo ou local onde serão expostos, o PAT deverá ser previamente comunicado, para efeito de efetuar o respectivo tombamento in loco.

Art. 60. O descumprimento do disposto neste Capítulo, quando ocasionar descontrole, imprecisão de características ou de quantidades e extravio de carga doada, implicará a responsabilização pela prestação de contas por parte do interessado no Centro de Custo que intermediou o processo de doação.

CAPÍTULO XI - Do Inventário Patrimonial 
Art. 61. O inventário físico dos bens patrimoniais será realizado anualmente, em todas as Unidades da FUB.

Art. 62. Para a realização do Inventário Patrimonial Anual, deverão ser constituídas, pelo DAF, uma Comissão Central de Inventário e Subcomissões de Inventário, cujos componentes serão indicados pelo Titular de cada Unidade, com um mínimo de três membros, sendo o seu Presidente Nato o Titular da respectiva Unidade, de acordo com o Decreto-Lei n. 200/1967 e a Instrução Normativa SEDAP n. 205/1988.

Parágrafo único. A Comissão Central de Inventário será integrada por servidores nãopertencentes ao PAT, sendo um deles servidor da CAL.

Art. 63. Os relatórios finais de Inventário Patrimonial Anual deverão ser encaminhados ao PAT, pela Comissão Central e pelas Subcomissões de Inventário, com cópia para a Comissão de Gestão de Bens Culturais, até o dia 30 de novembro de cada exercício, para integrar a Prestação de Contas Físico-Financeira da FUB.

Parágrafo único. A responsabilidade e co-responsabilidade pelo relatório de Inventário e o seu encaminhamento ao PAT são do Titular de Unidade e do Titular da Subunidade, respectivamente, e dele deverão constar a relação de bens móveis inventariados por agente, o relatório analítico por Centro de Custo, devidamente assinados, sendo que eventuais ocorrências detectadas na carga patrimonial deverão ser registradas e detalhadas.

\section{CAPÍTULO XII - Das Penalidades}

Art. 64. O descumprimento de dispositivos deste documento será considerado ato de improbidade administrativa, conforme disposto no Capítulo II da Lei n. 8.429, de 2/6/1992, o que sujeita o infrator às penas estabelecidas na Seção II do artigo 10 do mesmo Capítulo, independentemente das sanções penais, civis e administrativas previstas na legislação específica. 
Art. 65. Havendo fundados indícios de responsabilidade de servidor, por descumprimento das presentes normas, que resulte em dano ao patrimônio público, o Reitor determinará a imediata apuração dos fatos que será processada na forma prevista nos artigos 148 e 182 da Lei n. 8.112, de 11/12/1990.

CAPÍTULO XIII - Das Disposições Finais e Transitórias

Art. 66 A definição de normas para atualização de valores e depreciação de bens integrantes do patrimônio da FUB e a atribuição de valor a bens ou a peças doados à Instituição far-se-ão nos termos estabelecidos em norma complementar, editada pela Reitoria, a qual fará parte integrante deste documento.

Art. 67. Os casos omissos serão apreciados pelo Reitor ou por outra autoridade da FUB, mediante delegação de competência.

Brasília, 8 de setembro de 2004. 